\title{
OORZAAK EN SCHULD VAN DEN TWEEDEN PUNISCHEN OORLOG
}

DOOR

C. J. C. ARNOLD

AMSTERDAM - H. J. PARIS 



\section{OORZAAK EN SCHULD \\ VAN DEN}

\section{TWEEDEN PUNISCHEN OORLOG}





\title{
OORZAAK EN SCHULD VAN DEN
}

\section{Tweeden Punischen OORloG}

\author{
Akademisch Proefschrift \\ TER VERKRIJGING VAN DEN GRAAD VAN \\ DOCTOR IN DE LETTEREN EN WIJSBEGEERTE \\ AAN DE R.K. UNIVERSITEIT TE NIJMEGEN OP \\ GEZAG VAN DEN RECTOR MAGNIFICUS DR DE- \\ SIDERIUS FRANSES, HOOGLEERAAR IN DE \\ FACULTEIT DER HEILIGE GODGELEERDHEID, \\ VOLGENS BESLUIT VAN DEN SENAAT DER \\ UNIVERSITEIT IN HET OPENBAAR TE VER- \\ DEDIGEN IN DE AULA DER UNIVERSITEIT OP \\ MAANDAG 22 MEI 1939, DES NAMIDDAGS TE \\ VIER UUR, \\ DOOR
}

CHRISTIANUS JOHANNES CORNELIS ARNOLD GEBOREN TE TILBURG

AMSTERDAM - H. J. PARIS - MCMXXXIX 

AAN DE NAGEDACHTENIS MIJNER MOEDER VOOR MIJNE VROUW 

Bij de officieele beëindiging mijner academische studies wensch ik mijne oprechte dankbaarheid uit te spreken jegens allen, wier leiding en hulp ik heb mogen ontvangen.

In het bijzonder moge ik hier noemen de namen van de Professoren, die mijne studie in de Klassieke Letteren geleid hebben, Schrijnen, Drerup, Steffes en Sormant.

Een bijzonder woord van dankbare hulde moge ik wijden aan denagedachtenis van den Hooggeleerden SCHRIJ NEN, wiens beproefde en toegewijde leiding bij mijne studie in de Algemeene, Grieksche en Latijnsche Taalwetenschap ik steeds met groote waardeering zal blijven gedenken.

Hooggeleerde DrERUP! Aan Uwe toewijding dank ik de vorming van het Grieksche gedeelte mijner studie. Uwe groote en diepe kennis van de klassieke wetenschap, Uwe interessante en leerzame colleges zullen mij steeds in dankbare herinnering blijven.

Dat ik U, Hooggeachte SLIJPEn, niet slechts als Professor en Promotor, doch ook als Priester en Leidsman onzegbaar veel verschuldigd ben, moge ik ook hier vermelden. 


\section{N H O U D}

Blz.

H O F DSTUK I - HET PROBLEEM BIJ DE MODERNE HISTORICI .......... I

HOOFDSTUK II - DE AANLEIDING EN DE OORZAAK VAN DEN OORLOG ........

1 - De Bronnen . . . . . . . . . 18

2 - De schuldvraag van $219-218$ v. Chr. 35

H O O D T U K III - KARTHAGO VAN 241 TOT 218 VOOR CHR. ........... 49

HOOFDSTUK IV - DE POLITIEK VAN KARTHAGO EN ROME . . . . . . . . . $5^{8}$

LITTERATUUR. . . . . . . . . . . . . 81 


\section{HET PROBLEEM BIJ DE MODERNE HISTORICI}

De eerste historici en biographen, die reeds direct na, deels wellicht nog tijdens den tweeden Punischen oorlog het grootste conflict tusschen de twee machtigste volkeren van dien tijd beschreven, o.a. Chaereas en Sosylus ${ }^{1}$ ), gaven als oorzaken van den oorlog: het beleg en de inname van Saguntum door Hannibal en zijn overtocht over den Ebro. Maar reeds zeer spoedig, vermoedelijk direct na 200 v. Chr., voegde de Romeinsche senator $Q$. Fabius Pictor in zijn in het Grieksch geschreven annalen een nieuw motief in: de heerschzucht en de hebzucht van Hasdrubal, die tevergeefs een staatsgreep in Karthago had ondernomen en sindsdien zonder instemming zijner medeburgers en van de autoriteiten van Karthago in Spanje een onbeperkt gezag uitoefende, zou de oorzaak van den oorlog tegen Rome zijn, naast het onrecht tegen Saguntum; de oorlog zou dan ook tegen den wil van de Karthaagsche autoriteiten gevoerd zijn. Polybius, aan wien wij deze gegevens danken ${ }^{2}$ ), trekt de lijn naar boven door: niet Hannibal, noch Hasdrubal, maar Hamilcar is de eerste schuldige: verbitterd over het verliezen van den eersten Punischen oorlog, waarin hij zelf nooit een nederlaag geleden had, nog feller verbitterd wegens den onrechtmatigen roof van Sardinië in 237 door Rome, vestigde Hamilcar een machtig rijk in Spanje, ten koste van de Iberiërs, die niets misdaan hadden, om daarmee de middelen te verwerven om zich op Rome te wreken. Hij sneuvelde echter, voordat hij zijn plannen ten uitvoer kon brengen; zijn opvolger Hasdrubal breidde het Karthaagsche imperium wel uit, maar was meer diplomaat dan veldheer: eerst

I) Van het werk van Chaereas is zelfs de titel onbekend; Sosylus' werk heette

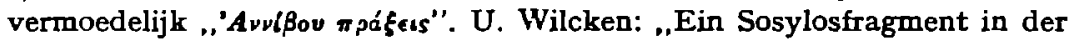
Würzburger Papyrussammlung". Hermes 4I (I906).

2) III 6-8. 
Hannibal voltrok de wraak, die hem als het ware als erfenis door zijn vader was nagelaten.

Polybius ${ }^{1}$ ) meent zijn opvatting te bewijzen met het verhaal, dat Hannibal, die, uit zijn vaderland gevlucht, aan het hof van Antiochus van Syrië vertoefde, den koning deed, toen deze hem wantrouwde om de groote hartelijkheid en vriendschap, Hannibal door Romeinsche gezanten bewezen: „Op het moment, dat Hamilcar op het punt stond naar Spanje over te steken en aan Zeus een offer opdroeg, stond Hannibal, toen negen jaar oud, bij het altaar. Toen het offer gunstig was verloopen en Hamilcar voor de goden geplengd en alle gebruiken vervuld had, beval hij den omstanders zich even terug te trekken, riep Hannibal echter tot zich en vroeg hem vriendelijk, of hij mede wilde ten oorlog. Blij zei Hannibal ,ja" en drong echt kinderlijk aan: Hamilcar nam hem bij de hand, leidde hem naar het altaar, en beval hem, met de hand op het offer te zweren, den Romeinen nooit gunstig gezind te zullen zijn"'.

Zoowel de Grieksche als Romeinsche schrijvers nadien hebben zich aan een dezer drie motiveeringen gehouden: het meeste geloof vond Polybius. Dit kwam onder meer voort uit het feit, dat hij niet stil stond bij de uiterlijke daden en feiten, maar dieper zocht naar de innerlijke beweegredenen in den mensch. Langen tijd hebben ook de moderne historici zonder critiek de opvatting van Polybius tot de hunne gemaakt, en dan liefst in den sierlijk uitgewerkten trant van Livius: zoo zelfs nog Niebuhr ${ }^{2}$ ), die zijn verhaal aanvult met gegevens uit Appianus, wiens werk hij ontleend acht aan de annales van Fabius Pictor ${ }^{9}$ ).

Een benijdenswaardig man onder de modernen was M. E. Hennebert 4: hij weet alles over Hannibal, zoowel over diens innerlijk als over zijn uiterlijk. Enkele der zeer vele trekken mogen hier vermeld: Hannibal had b.v. ", un oeil terrible" (I p. 248): „. . . torvaque oculos sub fronte minaces": Hennebert geeft ons dit bewijzend citaat uit - Silius Italicus IV!

Verder ,une abondante chevelure, que rattachait sans doute un riche bandeau: bewijs:

I) III II.

2) B. G. Niebuhr:: „Vortrăge über Römische Geschichte”. II, p. 45 ssqq.

3) O. 1. p. $6 r$.

4) „Histoire d'Annibal". Parijs 1870. 
„nec crinem Assyrio perfundere pugnet amomo": Silius Ital. XI en:

„crines nodantur in aurum": Verg. Aen. IV.

„Peut-être ces cheveux étaient-ils d'un blond cendré aux reflets d'or", want: Verg. Aen. IV spreekt van

„flaventesque abscissa comas".

Tot slot nog (I p. 249) „De riches anneaux pendaient aux oreilles" immers: „,incedunt cum annulatis auribus" zegt: „Plaute, Poenulus, acte V"'!

Op deze manier gaat Hennebert ook te werk bij de behandeling van de schuldvraag: hem zou de meest radikale annalist benijd hebben, van hem had zelfs Valerius Antias nog kunnen leeren.

Zeer serieus werk daarentegen leverde Otto Gilbert ${ }^{1}$ ). Voor hem is Polybius de schrijver, die om zijn pro-Romeinsche gezindheid de feiten willekeurig rangschikt en verzwijgt, die uit tendentieus voorgestelde gebeurtenissen onhoudbare en onjuiste conclusies trekt (o.1. p. 2); bij Diodorus, Appianus en Cassius Dio echter vindt hij overeenstemmende berichten, die teruggaan op Fabius Pictor. Daar dit door het bronnen-onderzoek sindsdien onwaar is gebleken, zijn alle conclusies van Gilbert in détailpunten onaanvaardbaar of onbewezen. Wat de oorzaak van den oorlog aangaat, combineert hij de opvattingen van Polybius en Fabius Pictor zeer handig in den trant van Diodorus: volgens Gilbert zeggen Polybius en Fabius in den grond precies hetzelfde, want Hamilcar was slechts een instrument in handen van den demagoog Hasdrubal (o.l. p. II7 ssqq.). Juridisch had Hannibal gelijk, want hij had het Ebroverdrag in $220 \mathrm{v}$. Chr. opgezegd, waartoe hij het volste recht had (o.l. p. I8r en 202); voor deze stelling brengt Gilbert geen argumenten. $\mathrm{Hij}$ aanvaardt den wrok der Barciden, maar legt alle nadruk op het feit, dat de Romeinen steeds het initiatief hebben genomen om de Karthagers te kwellen en te provoceeren. Wij deelen dit standpunt volkomen: jammer is, dat door de onjuiste beoordeeling der bronnen Gilbert zijn juiste stelling niet heeft bewezen.

Geheel Polybiaansch is weer de visie van Faltin ${ }^{2}$ ), Egelhaaf ${ }^{3}$ ),

I) Rom und Karthago in ihren gegenseitigen Beziehungen 513-536 u.c. Leipzig 1876 .

2) C. Neumann: „Das Zeitalter der Punischen Kriege”. Deel II, door G. Faltin. Breslau I883.

3) „Analekten zur Geschichte des zweiten punischen Krieges". Hist.Zeitschr. N. F. 17 ( $\left.188_{5}\right)$. 
en Mommsen ${ }^{1}$; de laatste schrijft vooral naar de bewerking van Livius, waarbij hij zijn verhaal nog pakkender maakt door toevoegsels uit Diodorus, Appianus, Cassius Dio of - uit eigen fantasie. Thiaucourt ${ }^{2}$ ) sluit zich vrijwel bij Gilbert aan, maar ook hij maakt te weinig onderscheid in de waarde der bronnen, zoodat hij niets verwerpt, maar alles door compromissen aaneenlijmt. Evenals Gilbert geeft hij alle gelijk aan Karthago - maar zonder deze stelling te bewijzen. J. Fuchs ${ }^{3}$ ) schrijft èn aan Rome èn aan Karthago den opzet tot den oorlog toe; vermeldenswaard is zijn opvatting van het krijgsplan der partijen: Hannibal wilde niet naar Italië gaan, maar deed alles om de Romeinen naar Spanje te lokken, waar hij de sterkste zou zijn: vandaar de beleediging van het Romeinsche gezantschap, het langdurige beleg van Saguntum, enz. De Romeinen echter wilden Hannibal naar Italië laten komen om hem daar te vernietigen. Hoe dit alles in overeenstemming gebracht kan worden met de uitdrukkelijke woorden van alle bronnen en met de feiten, zegt Fuchs niet, tenzij men argumenten aanvaardt als het volgende: Rome sloot met Saguntum een verbond, „damit sie (sc. de stad Saguntum) der Gradmesser der punischen Gefahr und ihr Fall der Weckruf für das schlummrende Italien sei" (o.l. p. 25); de woorden van Livius XXI, 6, 6: „erant qui non temere movendam rem tantam expectandosque ex Hispania legatos censerent" zouden slaan op de groep senatoren, die wel den oorlog wilden, maar die Hannibal naar Italië wilden lokken: „die dritte (sc. Partei) aber scheint überhaupt nicht für den Offensivkrieg gewesen zu sein, da sie durch das Zuwarten sich freiwillig des Vortheiles begab, den Gegner zwischen zwei Feuer zu bringen" etc.

Meltzer () aanvaardt de opinie van Polybius inzake de oorlogszuchtige bedoelingen der Barciden niet geheel en al: p. 398 heet het: „Selbstverständlich nahm in den Plänen Hamilkars und seiner Parteigenossen auch der Gedanke an die Möglichkeit eines neuen Krieges mit Rom einen Platz, sagen wir immerhin sogar einen

I) „Römische Geschichte”. Men zie o.a. W. Kolbe: „Die Kriegsschuldfrage von 218 v. Chr. Geb." pag. 5-6.

2) Thiaucourt: „Les causes et l'origine de la seconde guerre punique”. Parijs 1890 .

3) „Der zweite Punische Krieg und seine Quellen”. Wiener Neustadt I894.

4) Geschichte der Karthager II. Berlijn I896. 
hervorragenden Platz ein ..... Aber von einer solchen Auffassung der Lage ist es doch noch recht weit bis zu der schon oben gekennzeichneten, allerdings von Polybius selbst vertretenen Auffassung, als seien jene Männer nur von einer brennenden Sehnsucht nach möglichst baldiger Herbeiführung des Krieges beseelt gewesen". Dat Hasdrubal vrij was van die brandende oorlogszucht tegen Rome, concludeert Meltzer terecht uit zijn toestemming in het Ebroverdrag (o.l. 4I2-4I3); Hannibal hield ook wel rekening met de mogelijkheid van oorlog, maar heeft er zeker niet alles op gezet, om daartoe te komen (p. 4I9). Zijn resoluut optreden in Spanje trekt de aandacht van de Romeinen, die zich nu pas met Saguntum inlaten: in 220 zenden zij hun eerste gezantschap naar Hannibal, wel zonder positieven wil tot oorlog, maar wel bereid om den oorlog, als die eventueel uit hun actie zou voortvloeien, te voeren; en als Rome dan meent, dat Karthago op het laatste moment het hoofd zal buigen, stuit het op onverzettelijkheid: „Gesucht wurde der Krieg hier nicht, gescheut freilich auch nicht mehr" (o.1. p. 43I). De diepste oorzaak ziet Meltzer in de zwenking der Romeinsche politiek na het Ebroverdrag door het aangaan van het verbond met Saguntum: „Unter allen Umständen traf die Mehrheit des Senats, die doch das Eingreifen in Sagunt und die Gesandtschaft an Hannibal beschlossen haben muss, in der Ueberzeugung zusammen, dasz es unter den jetzt vorliegenden Umständen angebracht sei, der Wiedererstarkung Karthagos ein Hindernis in den Weg zu legen oder wenigstens eine Gelegenheit nicht von der Hand zu weisen, die sich irgendwann einmal bei eintretendem Bedarf in diesem Sinne werde ausnutzen lassen" (o.l. p. 425). Uitvoerig toont Meltzer aan, dat de Karthaagsche politiek als eerste principe voert: nooit veroveringsoorlogen te voeren, en slechts te vechten voor het behoud of de verwerving van handelsgebied (o.a. p. 226). Maar waar hij slechts twee groepen bronnen in de latere overlevering bewaard acht, n.l. die van Fabius Pictor en Polybius (p. 357 en 585 ssqq.), gelooven wij in het bestaan van een onafhankelijke derde groep ${ }^{1}$ ). Juist toonde hij aan, dat geen daad der Karthagers in deze periode hun oorlogswil bewijst: maar hij verzuimde de geheele Romeinsche politiek in deze periode te belichten; en toch

I) Zie Hoofdstuk II. 
kan het ontstaan van het conflict slechts uit de Romeinsche politiek verklaard worden. Zooals echter zijn werk onmisbaar is voor elke studie over Karthago, zoo is ook zijn rustige en duidelijke uiteenzetting in onze kwestie het punt van uitgang geweest voor allen na hem, die van de schuld van Rome overtuigd waren.

K. Lehmann ${ }^{1}$ ) schrijft aan Hamilcar niet alleen het besluit toe om den revanche-oorlog voor te bereiden, maar beweert ook, dat Rome hiervan op de hoogte was (o.l. p. 145). Voor deze bewering verwijst hij naar Pol. II 13, 3-6, waar echter niets van dien aard staat. En als Lehmann de afwachtende houding van Rome in 219 in overeenstemming probeert te brengen met hun beweerde kennis van Hannibals plannen, moet hij zijn toevlucht nemen tot den term: „republikanische Regierungsbehorde" - een term, die voor zijn Duitsche lezers misschien heel veel aannemelijk maakte; maar deze kleineering van den republikeinschen regeeringsvorm is heel slecht aanvaardbaar, daar Rome toch onder dien bestuursvorm zijn wereldheerschappij heeft gesticht. (,Denn zu einer überseeischen Expedition mit einem so gewaltigen Ziele waren so ungeheuere und für Rom bis dahin noch gänzlich beispiellose Streitkräfte und Geldmittel nötig gewesen, dasz einer republikanischen Regierungsbehorde ein so ungewöhnlicher Entschlusz nicht wohl zugetraut werden kann", etc.: o.1. p. 148 Anm.). De geheele opzet van het werk van Lehmann valt ineen, althans voor dit onderdeel, door de positieve mededeeling van het standpunt van Fabius Pictor (Pol. III 8), die als senator blijkbaar niets wist van de plannen van Hamilcar.

J. Kromayer ${ }^{2}$ ) voert het standpunt van Meltzer door: volgens hem heeft Rome juridisch ongelijk ${ }^{9}$ ); de oorzaak van het conflict lag in het streven van Rome naar de wereldheerschappij; Karthago wilde Rome slechts beletten om alle andere staten de bestaansmogelijkheden en de vrijheid te ontnemen. In zijn „,Roms Kampf um die Weltherrschaft" (Leipzig Igr2) handhaaft Kromayer dit standpunt, en toetst hieraan de geheele Romeinsche politiek in

1) „Die Angriffe der drei Barkiden auf Italien". Leipzig r905.

2) „Hannibal als Staatsman”. Histor. Zeitschr. Io3 (I909), p. 237-273.

3) „das Vorgehen Roms in dieser ganzen Angelegenheit (sc. Saguntum) ist erstens ein Bruch übernommener Verpflichtungen und zweitens ein flagranter Eingriff in Karthagos Interessensphäre gewesen" (p. 253). 
deze periode: zijn resultaten blijven dezelfde, maar zijn werk is te populair gehouden, bewijzen en bronnenvermelding mankeeren vaak, zijn redeneering is meestal te simplistisch en vaag.

U. Kahrstedt, die het $3 e$ Deel schreef ter voltooiing van Meltzers onbeëindigden arbeid ${ }^{1}$ ), ziet weer in de Barciden, de stichters van het imperium in Spanje, van begin af aan den opzet aanwezig om revanche te nemen: „Spanien war den Barkiden immer viel zu wenig Selbstzweck gewesen, seit den Tagen des Hamilkar hatte es nur die Basis gebildet, um den Rachekrieg gegen Rom vorzubereiten, man hatte nur so weit organisiert, wie es der $Z_{w e c k}$ erforderte, mit diesem Konglomerat einen auswärtigen Krieg zu führen, aber niemals so weit, dass dieses Gefüge von Gauen auch einen Stoss von aussen ertragen konnte, ohne mehr als lokale Wunden zu erleiden. Fand sich in Rom der Mann, dies zu durchschauen, den Krieg in Spanien zu wagen, trotzdem Hannibal in Italien einbrach, war der Plan gescheitert" (o.l. p. 367). Pag. 368 volgt dan nog de theorie over het gebrek aan medewerking van Karthago; Hannibal moest zijn volk in Karthago goed gestemd houden: „,ihr eine Deckung geben, die den ruhigen Fortgang des städtischen Handels und Wandels verbürgte, das souveräne Volk und die grossen Geschlechter bei guter Laune hielt und das Geschäft des Waffentragens auf sich nahm". Daarbij kwam nog het gevaar voor den afval der steden in Afrika, zelfs van overval door Numidische stammen, en opstand in Spanje.

Kahrstedt zette het werk van Meltzer voort: waar hij in voorname punten, als: de wil tot oorlog bij de Barciden, de schuld van Hannibal aan het uitbreken van den oorlog enz. zoo sterk van hem afwijkt, had hij zijn beweringen moeten bewijzen, want zijn voorganger - Meltzer in Deel II - vormt nu geen basis. Geen enkel argument staat er voor den oorlogswil der Barciden, noch van Hannibal apart; practisch gesproken hebben volgens Kahrstedt de Barciden den oorlog wel gewild, maar geenszins voorbereid: alles in onaf, op niemand of niets valt te vertrouwen; Hannibal weet dit, hij kent bovendien den vijand als zeer sterk, bijna onkwetsbaar - en dan laat Kahrstedt hem toch den verwekker van den oorlog zijn (,,der Mann, der die Verantwortung für den nun

I) Meltzer-Kahrstedt: „Geschichte der Karthager” III. Berlijn I9I3. 
beginnenden Riesenkampf trug" p. 366). Waar blijft, dat er veel mankeerde aan Karthagos macht ${ }^{1}$ ): doch dit geldt alleen, als men uitgaat van de stelling, dat de stichters en de leiders van die macht als eenig doel den oorlog tegen Rome kenden. Dit is echter nooit bewezen, ook niet door Kahrstedt, en zijn geheele redeneering in deze passage is direct bruikbaar voor het tegengestelde van wat hij beoogt: duidelijk blijkt, dat de Barciden, en speciaal Hannibal kortzichtige, roekelooze en tevens onvaderlandslievende generaals waren - of dat hun opzet geenszins een revanche-oorlog was, maar dat hun de oorlog is opgedrongen, en dat Hannibal geniaal naar omstandigheden gehandeld heeft, den Romeinschen opzet doorzag en dien trachtte te verhinderen.

Weinig nieuws brengen ons Veith ${ }^{2}$ ), wiens standpunt gelijk is aan dat van Polybius, en J. S. Reid ${ }^{3}$ ). De beweringen van Polybius, versterkt met die van Lehmann, keeren weer zonder nader bewijs terug bij de Sanctis 9): het geheele streven van Hamilcar, Hasdrubal en Hannibal was tegen Rome gericht; Spanje diende slechts als werfplaats en exercitieterrein voor de troepen en als schatkamer; reeds Hamilcar beoogde om vanuit Spanje over de Pyreneeën en Alpen naar Italië te trekken (o.1. p. 404). Hasdrubal sluit het Ebroverdrag, niet om daardoor de wraak prijs te geven, maar om tijd te hebben de verovering van Spanje te voltooien en te consolideeren (p. 4I3). Door Saguntum aan te vallen probeert Hannibal den oorlog te ontketenen: nog aarzelen de Romeinen, maar de imperialistische politiek, begonnen in $263 \mathrm{v}$. Chr., de naijver op de rijke winsten der Karthaagsche kooplieden, het bewustzijn van hun kracht en de vriendschap met Egypte deed hen tot den oorlog besluiten (p. 424-425).

Ook E. Meyer ${ }^{6}$ ) houdt zich aan de idee van Polybius, en vol-

I) Speciaal het ontbreken van een oorlogsvloot is bij de oude zeemogendheid zeer opmerkelijk.

2) "Antike Schlachtfelder in Italien und Afrika" von J. Kromayer, III 2 van G. Veith. Berlijn I9r2.

3) „Problems of the second Punic war" in de , Journ. of Roman Studies" III, p. I75-r96 (I913). Zijn argumenten zijn in alle Duitsche artikelen en werken vór hem te vinden; hij citeert echter niemand.

4) Storia dei Romani III 1. Turijn I9I6.

5) „Untersuchungen zur Geschichte des zweiten Pun. Krieges” in de Sitzungsberichte der Kön. Preuss. Akad. für Wissensch. I9I3. P. 688-7I 4. 
komen sluiten zich bij hem aan Drachmann ${ }^{1}$ ), Schnabel ${ }^{2}$ ) en Schur ${ }^{8}$ ). Meyer concludeert, dat Hannibal door het conflict om Saguntum beide partijen tot oorlog gedwongen heeft, maar ook (p. 7I2) ,dasz Hamilkar von Anfang an an einen neuen Waffengang mit Rom gedacht und die Gesinnung auf seine Söhne vererbt hat, würde geschichtlich zweifellos sein, auch wenn es nicht bezeugt wäre". Volgens Drachmann wilden de Romeinen den oorlog niet: „es scheint mir vielmehr klar, dass die Römer trotz allem was geschehen war einen Krieg in Jahre 218 fast um jeden Preis vermeiden wollten" (o.1. P. 2I, Anm. I); maar Hannibal en Karthago wilden zich ontdoen van het Ebroverdrag, daar hun de Ebro als grens niet veilig genoeg toescheen: zij begeerden de Pyreneeën als grens: „Der Gedanke an eine unmittelbare Nachbarschaft der beiden rivalisierenden Grossmächte mit einem Fluss als Grenze musste den Karthagern äusserst bedenklich sein; das Verhältnis musste zu Reibungen Anlass geben, die für den Frieden gefährlich werden konnten. Dagegen hatte Karthago an den Pyrenaeën eine ideale Grenze für seine spanische Herrschaft. Jenseits derselben lag Gallien, das zum Stosskissen wie geschaffen war; und gesetzt auch, dass die Römer hier festen Fuss fassten, was zunächst nicht zu erwarten war und tatsächlich erst hundert Jahr später geschah, so war die schwer übersteigbare Bergkette eine weit effektivere Scheidewand als der Fluss, der fortwährenden Verkehr hin und wieder gestattete" (p. 14-r5): d.w.z. het oorlogszuchtige Karthago, bang voor conflicten met Rome, begint den oorlog, om den oorlog te vermijden, met het vredelievende Rome, dat zich - ook Drachmann ontkent het niet - in Karthaagsch gebied tot onrechtmatige nterventie laat verleiden, waarbij het Ebroverdrag geschonden is, dat de Karthagers, maar niet de Romeinen, niet langer wilden erkennen!

Schnabel zegt p. II0: „Ebenso ist es seit den klassischen Darlegungen des Polybios im ersten Teil seines dritten Buchs für jeden Historiker klar, dasz im zweiten Punischen Kriege, Karthago, oder genauer, Hannibal und seine Partei der Angreifer de facto war,

r) „Sagunt und die Ebrogrenze,' in Histor. Filol. Meddelelser. 3e B. r920/r.

2) „Zur Vorgeschichte des 2en Pun. Krieges". Klio XX, I926.

3) "Scipio Africanus und die Begründung der römischen Weltherrschaft". Leipzig I927. 
der die Schmach des Friedens von 241 und des Raubes von 237 zu sühnen gewillt und berechtigt war. Das hat jüngst kein geringerer als E. Meyer von neuem ausgeführt, hoffentlich zum letzten Male".

Een geheel nieuwe oplossing wordt voorgesteld door Täubler ${ }^{1}$ ): niet de staat Karthago, die volgens Polybius de Barciden volgt in hun streven sinds den roof van Sardinië, noch Rome zelf, maar alleen Hannibal dwingt beide partijen tot oorlog: „Hannibal stand zwischen den Römern und den Karthagern und zwang beide gleichmäszig vor eine Frage, bei der an sich weder die einen, noch die andern viel verlieren oder gewinnen konnten. .... Aber in dem Augenblick, in dem der Konflikt offen wurde, beschränkte er sich nicht mehr auf Sagunt, sondern wurde zur Machtsfrage zwischen Karthago und Rom, die als konkretes Ziel für Karthago die Wiedergewinnung Siciliens und Sardiniens in sich trug". Verder werkt Täubler met het begrip van den ,geopolitischen Abschlusz": met den opzet om hun gebied ,geopolitisch" af te ronden, veranderen de Romeinen viermaal achtereen van inzicht: in 264, tusschen $24 \mathrm{I}$ en 238, van 238 tot 219 , van 219 tot 218 ! Daarmee worden gemotiveerd: respect. de eerste Punische oorlog, de roof van Sardinië, de verovering van Noord-Italië en de vestiging van de macht in Illyrië, en de tweede Punische oorlog. Zoo wordt ook het talmen van den Romeinschen senaat verklaard na den val van Saguntum: Rome was nog bezig ,,im geopolitischen Sinne Karthago gegenüber einen Abschlusz zu finden" (p. 76-77). Maar wat voor "Abschlusz" Rome zoeken moest in Spanje, waar het nog geen voet gronds bezat, vermeldt Täubler niet, evenmin hoe men met dit principe het Romeinsche gezantschap van 231 aan Hamilcar moet verklaren, het Ebroverdrag, of het ingrijpen in 220 in Saguntum. En wat moet men verstaan onder het zoeken naar een "geopolitischen Abschlusz"? Men kan die bereiken door gedeelten van het rijk af te staan - op die idee is Rome blijkbaar nooit gekomen - of door nieuwe stukken aan het rijk toe te voegen: hoe men dit dan noemt, doet weinig ter zake: het blijft expansie-politiek.

M. Holleaux ${ }^{2}$ ) gaat volgens eigen verklaring accoord met de opvattingen van de Sanctis; maar p. $136^{4}$ vervolgt hij: „Où je

I) „Die Vorgeschichte des zweiten Punischen Krieges". Berlijn 192 I.

2) ..Rome, la Grèce et les Monarchies Hellénistiques au IIIe siècle avant J. C." Parijs I92I. 
diffère d'avis avec de Sanctis, c'est lorsqu'il attribue d̀ une poussée d'„,impérialisme" la politique espagnole des Romains .... Je crois bien plutôt, que ce sont les inquiétudes, tradivement éveillées, du sénat qui déterminent ses résolutions et que si, finalement, il devient belliqueux, ce n'est que par crainte du péril dont les Puniques, trop actifs en Espagne, lui semblent menacer Rome". Elders probeert Holleaux althans nog argumenten te geven voor zijn opvatting over het gebrek aan imperialisme bij de Romeinen; hier laat hij zelfs dit pogen achterwege.

Daar zijn motief ,"vrees voor gevaar" terugkeert bij M. Gelzer ${ }^{1}$ ), vinde ook deze hier zijn bespreking. Gelzer immers aanvaardt (p. 157) het door Polybius verworpen bericht over Fabius Pictor ${ }^{2}$ ); hij vraagt zich af, waarom Fabius zoo uitdrukkelijk wees op de schuld van Hasdrubal en Hannibal: „Da scheint mir die Erklärung am nächsten zu liegen, dasz diese Nachricht von der Desavouirung Hannibals durch die maszgeblichen Politiker Karthagos auf die römischen Gesandten des Jahres 220/2r9 zurückging, über deren Tätigkeit Polybios 15. 13 so merkwürdig rasch hinwegeilt. In Rom muszte man daraus folgern, dasz von Seiten Karthagos keine Kriegsgefahr bestehe, und dies mag in Wahrheit ein Grund gewesen sein, warum Rom im Jahre 219 nichts tat in Spanien. Im Gegensatz zu de Sanctis (III 2,2) bin ich der Ansicht, dasz Fabius hiermit eine für die römische Politik eine grundlegende Tatsache mitteilte". Als Hannibal dan Saguntum ingenomen heeft, moet Rome zijn uitlevering eischen: „Nach Polybios 20,7 war die römische Forderung, Hannibal und seine Ratgeber auszuliefern, für Karthago eine Unmöglichkeit, weil sie Schande und Schaden zugleich bedeutete. Von den Römern war sie jedoch durchaus ernst gemeint. Es sollte so klargestellt werden, ob die der frühern römischen Gesandtschaft erteilte Antwort, Hannibal handle ohne Ermächtigung der heimischen Regierung, wirklich zutraf (2I,6-7). Das Auslieferungsbegehren beruhte auf der - wie sich im Laufe der Verhandlungen herausstellte - falschen Voraussetzung, dasz Hannibal auch jetzt noch von der Karthagischen Staatsleitung abgeschüttelt würde. Aber die politische Gruppe, die das zweifellos noch wollte, war zu schwach, die Schmach $(34,8)$ zu grosz, und Hannibal hatte in-

I) „Römische Politik bei Fabius Pictor". Hermes 68. Heft 3 (1933).

2) Pol. III 8. 
zwischen seine Stellung in Karthago befestigt (die Andeutungen II I5, 8; (7, 7)" 1). Zoo komt dus de oorlog: Rome moet zijn bondgenooten wreken: dat eischt de fides Romana: „Die Senatoren der Hannibalzeit haben ihre Entscheidung aufs gründlichste überlegt. Ihre Gedanken kreisten jedoch um die Begriffe Sicherheit und Ehre des Staats". De geheele redeneering van Gelzer berust op de stelling, dat de Karthaagsche senaat bij het eerste gezantschap het optreden van Hannibal desavoueerde. De stelling is onbewezen, en apert onjuist. Inderdaad verzwijgt Polybius het Karthaagsche antwoord: dat het juist het tegenovergestelde behelsde van wat Gelzer denkt, blijkt:

$I^{\circ}$ uit wat Polybius direct laat volgen (III I5, I2-I3): „O $O \dot{i} \delta \dot{\varepsilon}$

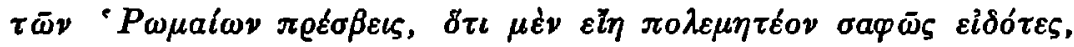

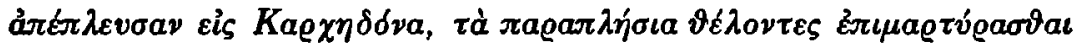

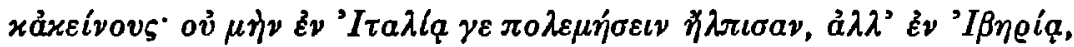

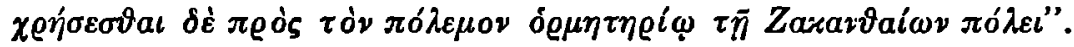
$\mathrm{Na}$ den terugkeer der gezanten te Rome wil de senaat vlug de Illyrische kwestie afhandelen, omdat de Karthaagsche oorlog langdurig en zwaar zal zijn: dat sluit de mogelijkheid van een gunstig antwoord van den Karthaagschen senaat uit.

$2^{\circ}$. Hannibal vraagt te Karthago om instructies en gaat dan Saguntum belegeren (III 15,8 ). Deze houding is niet vereenigbaar met een desavoueeren van zijn optreden. Bij Livius (XXI, Io) en Appianus (Iber. Io), die het antwoord van den Karthaagschen senaat niet verzwijgen, keurt deze het gedrag van Hannibal openlijk goed.

$3^{\circ}$. Juist indien Karthago Hannibal desavoueerde, zou Rome het belegerde Saguntum zeker geholpen hebben, daar Hannibal dan zeer zwak stond: minder dan ooit behoefde de Illyrische expeditie een bezwaar te zijn.

$4^{\circ}$. Als veiligheid en eer de eerste principes waren van de toenmalige Romeinsche politiek, had Rome veeleer een bevriende stad moeten helpen, dan haar geduldig laten verwoesten, zeker indien de aanval geleid werd door een veldheer, van wien men wist, dat hij optrad tegen den wil van zijn regeering.

$5^{\circ}$. De opvatting, dat de Romeinen louter uit „Sicherheit und

I) o.1. p. 159 . 
Ehre des Staats" juist in deze periode hun wereldheerschappij hebben gesticht, is in strijd met andere, onweerlegbare feiten ${ }^{1}$ ) en met het gezonde verstand.

Ehrenberg ${ }^{2}$ ) beziet de geheele kwestie wegens den aard van zijn werk, dat in groote lijnen zeer goed de traditioneele handelspolitiek van Karthago behandelt, slechts van den Karthaagschen kant: nooit kende volgens hem Karthago revanche- of veroveringsoorlogen; het trachtte echter steeds zijn handel te beveiligen. De verovering van Spanje is voor hem dan ook - en terecht — ,nicht der erste Teil eines konsequent durchgeführten Kriegsprogramms" — „sondern eine Schöpfung, die ihren Sinn durchaus in sich selbst trug. Der Gedanke des Krieges gegen Rom ist stets lebendig gewesen, aber niemals das eigentliche 'agens' gewesen. Gerade Hasdrubal, dessen grosze persönliche Stellung als „unumschränkter Stratege aller Iberer" schon für die Zeitgenossen Anlasz war, in ihm einen Haupturheber des Krieges zu vermuten, hat jenen Vertrag (sc. het Ebroverdrag) abgeschlossen" (p. 30-3I). Als Rome dan het Ebroverdrag door zijn interventie in Saguntum geschonden heeft, grijpt Hannibal in: „Dann allerdings hat er den psychologischen Moment ergriffen und Rom wie Karthago vor die vollendete Tatsache des Angriffs gestellt. Er hat den Krieg gewollt in den Augenblick, da er ihn für nicht mehr vermeidbar hielt, und er hat damit das selbstverständliche getan, so etwas wie Perikles vor dem peloponnesischen Krieg"' (p. 32). Hannibal handelde echter, zooals we zagen, in overeenstemming met zijn regeering; daarmee vervalt de laatste bewering van Ehrenberg. Ook bewijzen de discussies in den Romeinschen senaat na den val van Saguntum, dat zelfs toen de oorlog nog niet onvermijdelijk was: Hannibal en Karthago weken weliswaar niet voor de Romeinsche provocatie, maar den oorlog hebben de Romeinen ongetwijfeld gewild en ook verklaard.

De gewone, hoofdzakelijk op Polybius berustende voorstelling vinden we bij E. Pais ${ }^{3}$ ) en in Boek VII-VIII van de Cambridge Ancient History. Groag /) echter voert het standpunt van Meltzer

I) Zie Hoofdstuk IV.

2) Karthago: „Morgenland: Darstellungen aus Geschichte und Kultur des Ostens". Heft I4. Leipzig 1928.

3) "Storia di Roma durante le guerre Puniche I" (pag. I83 ssqq.) Rome I 927.

4) "Hannibal als Politiker". Weenen r929. 
en Kromayer strikt door: terecht concludeert hij uit het Ebroverdrag, dat de politiek der Barciden niet offensief tegen Rome gericht was (p. 4r); ook Hannibal zocht den oorlog niet: „Es schien im Interesse Roms zu liegen, der Ausbreitung und Konsolidierung des karthagisch-spanischen Reiches einen Riegel vorzuschieben und selbst den Schluissel zu Spaniens Reichtümern an sich zu nehmen. Die Gier nach den Metallschätzen Iberiens, deren Ausbeutung man den Puniern miszgönnte, wird bei dem Eingreifen der Römer sicherlich eine ausschlaggebende Rolle gespielt haben" (p. 52). Het besluit van den Romeinschen senaat om Karthago door het ultimatum practisch tot oorlog te dwingen, noemt Groag zeer juist een overwinning van de imperialistische oorlogspartij (p. 72); maar zijn opvatting van de „Festlandspolitik", die Rome tot dan toe gevoerd zou hebben, is beslist onjuist: de eerste Punische oorlog was reeds een verdrijven der Puniërs van de zee (zie Hoofdstuk IV), wat niet weerlegd wordt met de woorden „Sizilien und Sardinien waren noch Vorländer Italiens"; en ook de twee Illyrische oorlogen, die aan den tweeden Punischen voorafgingen, werden gevoerd om de hegemonie in de Adriatische zee. Groag gaat ook te ver in het toeschrijven van vreedzame bedoelingen aan den Karthaagschen senaat, als hij verklaart, dat de senatoren zwegen ${ }^{1}$ ) over het Ebroverdrag in de zitting, waarin de Romeinen den oorlog verklaard hebben, met de bedoeling om Rome de schending van dit verdrag niet te hoeven verwijten en het hun zoo gemakkelijk te maken alsnog te retireeren: de Romeinen kwamen met bindend mandaat namens den senaat; van retireeren kon dus geen sprake zijn.

W. Otto ${ }^{2}$ ) kan in de "Schuldfrage" geen schuldigen ontdekken. Hamilcar, Hasdrubal en Hannibal stichten zonder eenige vijandige bedoelingen in Spanje hum imperium (p. 495); Rome grijpt in $23 \mathrm{I}$ en in 219 wederrechtelijk in, en Hannibal wordt gedwongen zich te verdedigen ,zumal es sich hierbei um die Blüte und Grösze des karthagischen Staates, um eine Existenzfrage für ihn handelte"

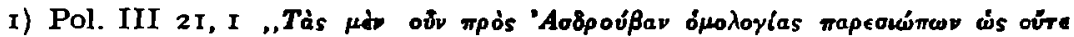

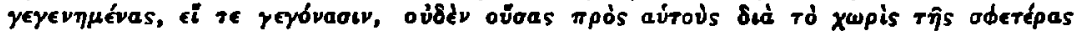

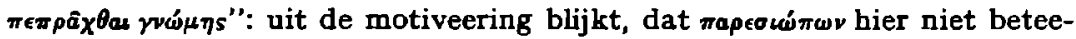
kent „zwijgen over", maar ,,verwerpen": immers, iets waarover men zwijgt, kan men moeilijk motiveeren.

2) „Eine antike Kriegsschuldfrage”. Histor. Zeitschr. I45, Heft 3. P. 489-516. 
(p. 507-508); maar dit optreden van Rome is nog geen imperialistische expansiepolitiek, doch slechts - „Ausdehnungstrieb”! Otto wil überhaupt geen schuldigen aanwijzen: „Hier hat sich vielmehr ein gewaltiges Schicksal vollzogen, der Zusammenprall mit einander unvereinbarer Interessen, die sich bei groszen Völkern ebenso wie bei allen anderen lebenden Individualitäten mit Notwendigkeit auswirken müssen" (p. 5I5). Deze uitspraak, die èn de eene partij vrijspreekt èn de andere niet beschuldigt, komt practisch neer op de conclusie: slechts Rome is schuldig - een uitspraak, waar we ons volkomen bij aansluiten, al heeft Otto zijn oordeel dan ook niet voldoende gemotiveerd.

Zonder nieuwe argumenten bij te brengen aanvaardt Pietro Treves ${ }^{1}$ ) den opzet der Barciden tot den oorlog, naast de antikarthaagsche politiek van Rome; hij erkent dat het ingrijpen in Saguntum door de Romeinen schending van het Ebroverdrag was, wat hem een hevige reprimande op den hals haalt van zijn landgenoot Carmen Scano ${ }^{2}$ ), die zich aan Luigi Pareti ${ }^{3}$ ) houdt. Deze vindt de juridische kwestie onbelangrijk genoeg om haar te verzwijgen; hij aanvaardt alle argumenten van Polybius zonder verdere critiek, en concludeert, evenals Otto, dat de oorlog een noodzaak was, daar er voor de twee grootmachten Rome en Karthago geen vreedzame samenleving mogelijk was.

Om de voor Duitschland typisch-moderne wijze van argumenteeren zij de laatste schrijver over ons onderwerp nog iets uitvoeriger geciteerd. Het is Walther Kolbe \%), die de juridische kwestie ten ongunste van de Karthagers beslist: deze hadden bij het eerste gezantschap van 220 de rechtsgeldigheid van het Ebroverdrag moeten bestrijden: door dit niet te doen, - en dat ze het niet deden, weet Kolbe, zooals Gelzer, uit het stilzwijgen van Polybius hebben zij het in 220 stilzwijgend aanvaard, en in 218 bij de onderhandelingen weer verworpen: „Und nun kamen plötzlich die Diplomaten und bewiesen mit spitzfindiger Logik, dasz der Vertrag von

I) „Le origine della seconda guerra Punica”. Atena e Roma XIII, I932.

2) „Di un storico Cartaginese” in: „Historia. Studi Storici per l'antichità classica", P. 331-337. Milaan-Rome I933.

3) „Ancora sulle cause della seconda guerra punica". Atena e Roma XIII (1932), p. 39-43.

4) „Die Kriegsschuldfrage von 218 v. Chr. Geb." Sitzungsbericht der Heidelb. Akad. 1933/4. 
226 nichtig sei, weil ihm die Ratifikation durch den Senat fehle, und dasz infolgedessen der Karthagische Staat durch jenes Abkommen in keiner Weise gebunden sei. Das war jedoch eine durch und durch verlogene Haltung, das war Rabbulistik, wie sie wohl die semitischen Händlerseelen ausdenken, aber nun und nimmer ein klar und einfach empfindender Römer jener Tage nachfühlen konnte. Das war Vertragsbruch perfidester Art" (p. I9). We zien hier bij Kolbe duidelijk den invloed van de „Rasse-Theorie": hij publiceert in 1934 !

Maar hoe kwamen die ,klar und einfach empfindenden Römer" dan aan het recht om ten zuiden van den Ebro, in het imperium, dat ze zelf als zuiver-Karthaagsch erkend hadden, in te grijpen? „Saguntum was vó́r 226 bondgenoot van Rome, en genoot dus de bescherming van het Ebroverdrag"! (p. 17). Maar „politisch" was Karthago onschuldig; in Rome werkten, volgens Kolbe, aanvankelijk krachten, die de verdragen wilden eerbiedigen, maar na den eersten Punischen oorlog kreeg langzamerhand die richting de overhand, „die die augenblickliche Gunst der Umstände - selbst unter schroffer Verletzung des Rechts - zu einem groszen Erfolge ausnützen will" (p. 32). En dan vervalt Kolbe in de meest onmogelijke tegenstrijdigheden: „Das Ziel der auf Aktivität drängende Kräfte ist nicht zu verkennen. Man wollte über die natürlichen Grenzen der Apenninhalbinsel hinausgreifen und den Blick auf die See richten"' (p. 33); Rome neemt dan de bescherming der Grieken op zich ,,als Erbe der westgriechischen Staaten"; het kan niet anders, en deze bescherming is ook ,der tiefste Sinn des ersten Punischen Krieges". Wie spreekt nu nog van de Mamertijnen? En verder: „Italien wurde, ohne Eroberungspolitik zu treiben, eine Balkanmacht und trat damit in eine zunächst noch verborgene Rivalität zu Makedonien". Als voorvechter voor de Grieksche belangen legt Rome in "den beiden Adriakriegen ... . die Grundlagen für jene scheinbar so uneigennützige und doch für Griechenland so verhängnisvolle Politik der Befreiung aller Griechen, die nach einem Menschenalter zu dem Triumph des T. Quinctius Flamininus geführt hat. Rom treibt nicht imperialistische Politik in dem groben Sinn der Eroberung. Wohl aber erhebt es den Anspruch, dasz sein Wort auch jenseits des Meeres gehört werde" (p. 33). Men ziet, zonder opzet sticht ook volgens Kolbe Rome zijn wereldheerschap- 
pij: de redeneering is die der Romeinsche annalisten, speciaal die der Romeinsche onderhandelaars bij de Grieken voor het werven van bondgenooten, beschreven in Livius' 4e decade ${ }^{1}$ ). Slechts Karthago wordt iets milder beoordeeld: „Vor dem Gericht hat Karthago das Prozesz verloren. Aber moralisch steht es ohne Makel da" (p. 39). Tot slot moge ik verwijzen naar de woorden in 1934 geschreven, die nu wel een bijzondere beteekenis krijgen: ", in der antiken Welt ist es noch immer ein Zeichen innerer Kraft und Gesundheit gewesen, den Nachbarn dem eigenen Wille gefügig zu machen".

r) Men zie o.m. Livius XXXI, c. 31 . 


\section{DE AANLEIDING TOT DEN TWEEDEN PUNI- SCHEN OORLOG}

\section{I - DE BRONNEN}

A - CHAEREAS, SOSYLUS, SILENUS, CATO EN CASSIUS HEMINA

Als schrijvers over den tweeden Punischen oorlog vóór Polybius kennen we de Grieken Chaereas, Sosylus en Silenus; de Romeinen Fabius Pictor, Cincius Alimentus, Ennius, Cato, Postumius Albinus en Cassius Hemina. Van hun werk zijn nog slechts fragmenten over: daar Polybius echter de oorzaken, door zijn voorgangers opgegeven, polemiseerend vermeldt, kunnen we nog nagaan, wat hun standpunt was.

In zijn inleiding van boek III, waar hij de aanleiding behandelt, schrijft hij (III 6):

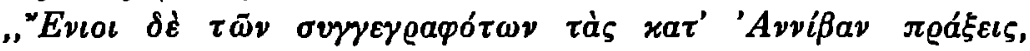

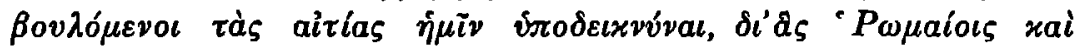

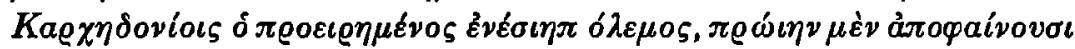

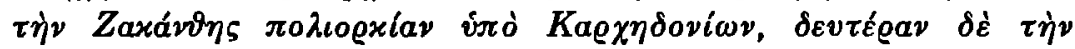

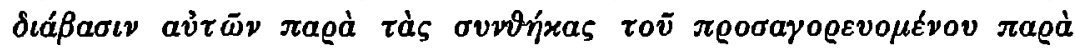

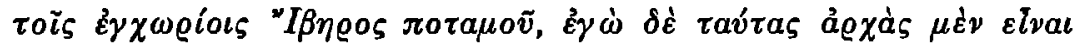

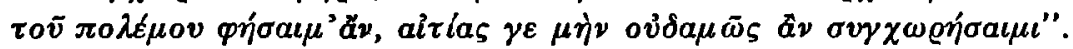

Uitdrukkelijk beweert Polybius dus, dat somnige schrijvers als oorzaken opgeven: het beleg van Saguntum en het overtrekken van den Ebro. Onder deze "Evio worden terecht algemeen op de eerste plaats Chaereas en Sosylus verstaan: in III 20, I-6 polemiseert Polybius fel tegen hen:

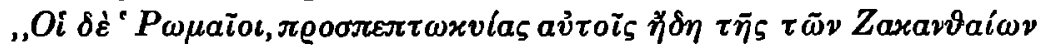

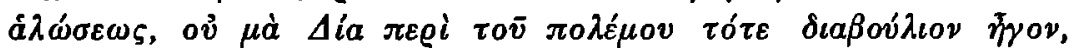

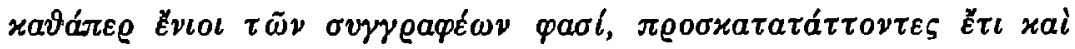

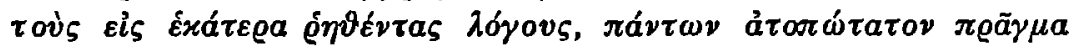




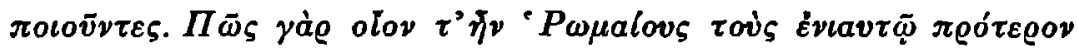

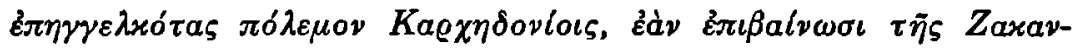

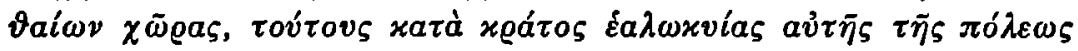

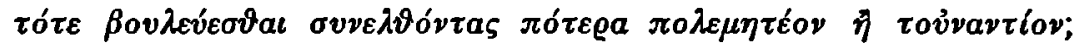

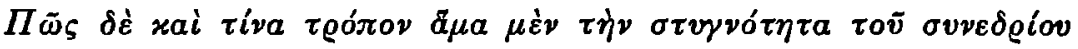

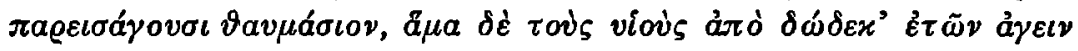

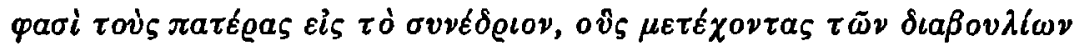

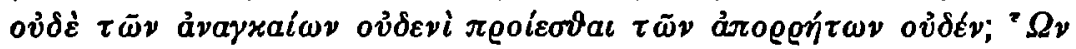

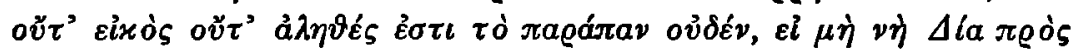

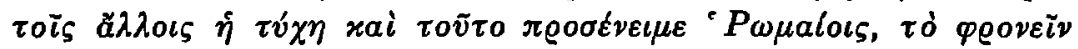

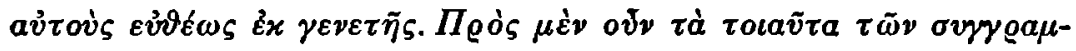

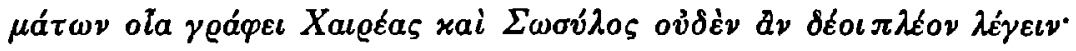

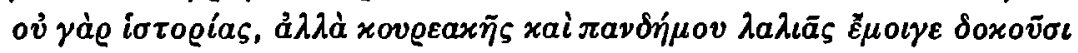

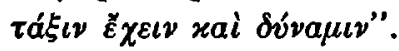

Polybius kent dus Chaereas en Sosylus; en bestrijdt hen ook in III 6: want de andere, van zijn opgave afwijkende, motiveering van den oorlog vermeldt hij als van Fabius Pictor (III 8). Ook de woorden: $\tau \dot{a} \zeta$ $x \dot{\alpha} \tau$ ' 'Avvißav $\pi \varrho \alpha^{\prime} \xi \varepsilon \iota$ vormen een aanwijzing in die richting: we weten immers sinds de vondst van een bladzijde uit het werk van Sosylus ${ }^{1}$ ), dat de titel van diens werk inderdaad

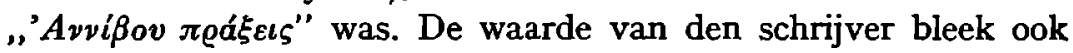
veel grooter dan men om de honende critiek van Polybius tot dan toe aangenomen had $^{2}$ ).

In de critiek III 6 richt Polybius zich niet tegen de feiten, maar tegen den term aitlas; hij vindt hierin bij alle schrijvers na hem bijval. En toch slechts gedeeltelijk terecht, ook als de overtocht van Hannibal over den Ebro plaats had na de oorlogsverklaring: het beleg van Saguntum stelt Polybius zelf vóór de oorlogsverkla-

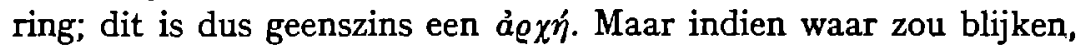
dat Hannibal Saguntum veroverd heeft en gelijktijdig, althans vóór de oorlogsverklaring, de Ebro niet langer als grens voor het Karthaagsch imperium heeft willen beschouwen, heeft Polybius geheel en al ongelijk, en verdienen Chaereas en Sosylus geenszins zijn

I) Uit de Würzburgsche verzameling van papyri gepubliceerd en besproken door U. Wilcken in Hermes $4 \mathrm{I}$ (1906) P. I03-I4I.

2) Wilcken o.1. p. I40 ,Der Haupteindruck, den ich von diesem Fragment habe, is der, dasz Sosylos als Historiker und Schriftsteller höher steht, als nach dem scharfen Urteil des Polybios anzunehmen war'. 
smadelijke critiek. Indien er nu geen ander middel restte om in deze achter de waarheid te komen, zou het nog beter aanvaardbaar zijn, dat Polybius uit partijzucht voor de Romeinen de feiten verdraaide, dan dat schrijvers, die meegemaakt hadden wat ze schreven ${ }^{1}$ ), zonder reden vervalschingen zouden hebben gepleegd: (wat goeds kwam er immers voort voor Hannibal uit deze falsificaties?) of uit domheid niet meer geweten zouden hebben wat vóór en wat na de oorlogsverklaring geschied is: want hierop komt zijne beschuldiging neer, en niet op de vraag of ze scherp onderscheid gemaakt hebben tusschen de aanleiding en de diepste, ware oorzaak.

Hoe is nu deze zegswijze van Polybius ontstaan?

Volgens Polybius heeft de Romeinsche Senaat direct na den val van Saguntum zonder discussies tot den oorlog besloten. Er bestond echter een traditie, die van beraadslagingen in den Romeinschen senaat wist: sommige senatoren zouden bezwaar hebben gemaakt om roekeloos een gevaarlijken oorlog te ondernemen; andere zouden voorgesteld hebben gelijktijdig zoowel Spanje als Afrika aan te vallen: het resultaat zou zijn geweest, dat een gezantschap werd gezonden, om de uitlevering te eischen van hen, die schuldig waren aan den ondergang van Saguntum: werd deze uitlevering geweigerd, dan moest de oorlog verklaard worden. Deze opvatting, waartegen we de felle polemiek van Polybius lazen, vinden we nog aanvaard door Cassius Dio, zooals blijkt uit fragment 54 en uit Zonaras VIII 22 (Melber p. I96 ssqq.) 2). De historiciteit der discussies in den senaat staat echter vast, ondanks Pólybius:

$I^{\circ}$. niet alleen Chaereas en Sosylus, maar, naar we zien zullen, ook Romeinen vermeldden ze: daar er geen voordeel voor Rome uit voortvloeide, noch ook voor Hannibal, is er geen grond geweest tot verzinsels;

$2^{\circ}$. Polybius brengt als tegen-argument feitelijk niets anders dan een scheldpartij tegen Chaereas en Sosylus.

Maar deze onzekerheid van den senaat werd later een zeer ongelegen factor in de redeneering van hen, die den oorlog ondernomen wilden zien „ob fidem Romanam”, de bekende „fides colendi socios": ') daarom lichtte Polybius deze beraadslaging uit de over-

I) Nepos, Vita Hannil. 13, 3 .

2) Zie citaat p. 22

3) Livius XXVI 24, 3; Gelzer: „Röm. Politik bei Fabius Pictor:" Hermes 68 (1933) p. I45 en p. 163. 
levering; maar daarmee moest ook vervallen alles, wat geschied was na de inname van Saguntum en vóór de oorlogsverklaring.

In den text, zooals Polybius dien geeft, vinden we nog enkele uitdrukkingen, die bevreemden, als we aannemen, dat Chaereas en

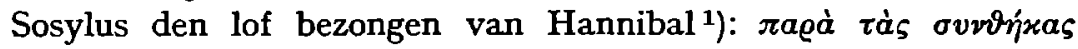
(III 6, 2): schrijvers, door Hannibal aangesteld om zijn roem te verkondigen, zullen deze uitdrukking wel niet gebruikt hebben. Maar hoe zouden zij in hun werk den bewonderenswaardigen ernst bezingen van den Romeinschen senaat, en de volmaakte betrouwbaarheid en flinkheid der twaalfjarige Romeinsche jongens, die, zonder risico van geheimen te verraden, deel konden nemen aan de geheime vergaderingen hunner vaders-senatoren? (Pol. III 20, 2). Ondanks het feit, dat Polybius slechts Chaereas en Sosylus noemt, bestrijdt hij hier tevens Cato, den auteur van de Origines: want Aulus Gellius beroept zich voor zijn verhaal over de gewoonte der Romeinsche senatoren om hun nog jeugdige zonen mee te nemen naar de senaatszittingen, op het getuigenis van Cato Maior $\left.{ }^{2}\right)$. De opvatting, dat de verovering van Saguntum en de schending van het Ebroverdrag de oorzaken van den tweeden Punischen oorlog waren, is dus niet slechts van Chaereas en Sosylus, maar ook die van Cato Maior! De bevestiging van deze conclusie vinden wij bij

I) H. Dessau (,,Ueber die Quellen unseres Wissens vom zweiten Punischen Krieges", Hermes 5 I, I 9 6, p. 355 ssqq.) concludeert uit het Sosylusfragment, dat Sosylus absoluut niet pro-Karthaagsch was, dat dit ook absoluut niet staat bij Nepos Hannib. 13, 3: „,cum en in castris fuerunt simulque vixerunt quamdiu fortuna passa est" d.w.z. dat zij dus niet tot het einde toe in de pro-Hannib, gezindheid volhardden. Hier trekt Dessau een verkeerde conclusie ,quamdiu fortuna passa est": zoolang hebben ze tot het gevolg van Hannibal gehoord. Dat ze daarna Hannibal niet meer bewonderden, staat er niet. In hun aanwezigheid bij Hannibal ligt natuurlijk wel indirect opgesloten, dat ze pro-Hannibal waren: maar voor wat er indirect staat, is de directe toevoeging niet noodzakelijk een beperking. Integendeel, welke schrijver in de oudheid zou na de verandering in de gezindheid nog een werk

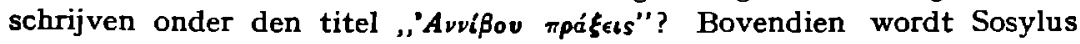
door Nepos Hannib. 13, 3 samen genoemd met Silenus: en men zie Pol. III 47, 6 de felle critiek tegen de verheerljjkende voorstelling van Hannibal. door Silenus gegeven! (Conf. Cic. de Div. I 24, 49). Men zie ook Drachmann: "Sagunt und die Ebro-Grenze" in Hist. Filol. Meddelelser ze Deel 1920/2I p. 4 .

2) Aulus Gellius I 23. 
Cassius Dio: bij Zonaras VIII 22 (Melber p. I96-200) lezen we, na het verhaal van de verovering van Saguntum: ,Kai $\delta \imath^{\prime}$ avं

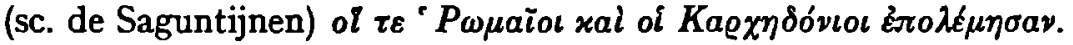

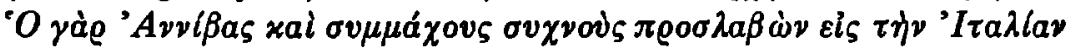

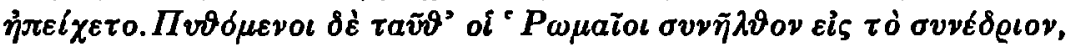

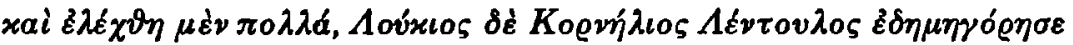

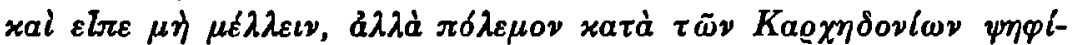

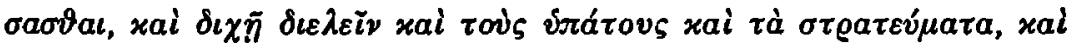

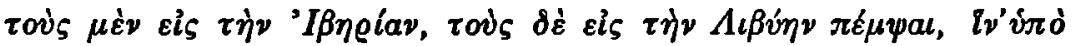

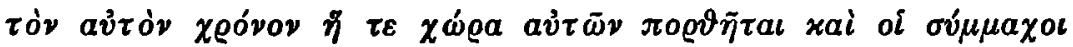

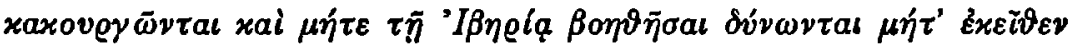

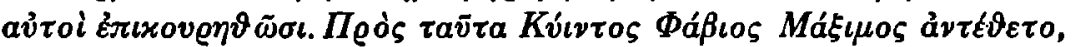

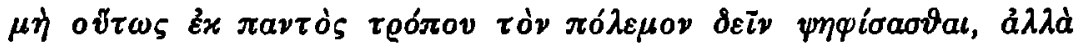

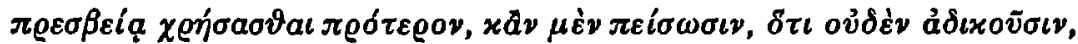

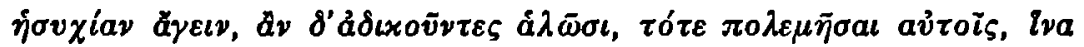

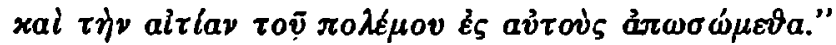

Immers, we vinden hier de bevestiging van al wat Polybius III 6, I-2 bestreed: als eerste oorzaak het beleg van Saguntum, als de tweede, in sterkst mogelijken vorm, de overschrijding van den Ebro; (Pol. III 20): de beraadslagingen in den senaat te Rome en zelfs de redevoeringen pro en contra! Hiermee wil niet gezegd zijn, dat Polybius het werk van Cato zelf voor zich had: deze immers gaf in zijn werk slechts plaats aan zijn eigen redevoeringen; maar vóór Polybius schreven behalve Fabius Pictor, van wien Polybius uitdrukkelijk een andere motiveering vermeldt, en Ennius, die Pictor volgde ${ }^{1}$ ), L. Cincius Alimentus, Postumius Albinus en Cassius Hemina. Van Alimentus weten we, dat hij zijn werk in het Grieksch schreef, zich nauw aansluitend bij zijn voorganger Fabius, en dat hij vermoedelijk publiceerde tusschen 190-I80 v. Chr.: hij valt dus als mogelijke bewerker van Cato's Origines reeds uit. Resten nog Postumius Albinus en Cassius Hemina: bij dezen is invloed van het werk van Cato duidelijk ${ }^{2}$ ): waarschijnlijk is dus, dat Polybius dit recente werk ${ }^{\text {I) }}$ bestreed.

r) Confer infra.

2) Schanz-Hosius: „Geschichte der Röm. Litteratur" I, p. 194-I95.

3) Hij schreef voor r 46 v. Chr.: want de titel van zijn 4e Boek was „,Bellum Punicum posterior". Schanz-Hosius 1.1. 
Het is dus geen late annalist die, zooals Meyer vermoedde ${ }^{\mathbf{1}}$ ), schreef: „In diesem Jahre brach der Hannibalische Krieg aus; er ist dadurch herbeigeführt, dasz die Karthager zunächst die mit Rom in Bündniss stehende Stadt Sagunt angriffen und dann gegen den Vertrag den Ebro mit einem Heer überschritten". Geen annalist mogen we verdenken als verzinner van deze passage bij Cassius Dio, al heeft deze zijn bericht natuurlijk lang niet uit de eerste hand, en al hebben de annalisten inderdaad genoeg verzonnen en vervalscht. $Z i j$ hebben zich nooit bekommerd om de waarheid: steeds sterker spreekt de tendenz, om Karthago als schuldig aan den oorlog voor te stellen, Rome echter in een gunstig daglicht te plaatsen: schrijvers als Diodorus, Appianus e.a. zijn daar fraaie voorbeelden van. Dat Rome na den val van Saguntum en het verbreken van het Ebroverdrag nog gedelibereerd zou hebben over vrede of oorlog, verwierp, zooals we zagen, Polybius, als in strijd met de eer der Romeinen. Dat een latere annalist dit weer op eigen initiatief zou uitvinden ter eere van de Romeinen, is dus uitgesloten.

Het is dus deze verdragsschending, welke Cato bedoelt in fr. 84 (Peter. Hist. Rom. Rel. I, p. 8I) „Cato in quarto originum: Deinde duodevicesimo anno post dimissum bellum, quod quattuor et viginti annos fuit, Carthaginienses sextum de foedere decessere". Het zal goed zijn, deze punten vast te houden voor de bespreking van Pol. III 30,3 , een plaats, die reeds tot de meest onmogelijke fantasieën geleid heeft. Voordien moeten we echter nog Silenus bespreken; daarna Fabius Pictor en Ennius.

Weer is Polybius punt van uitgang: III 47,6 spreekt hij over

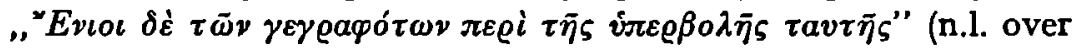

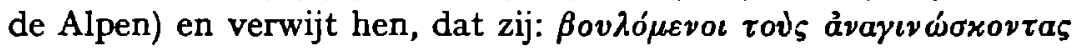

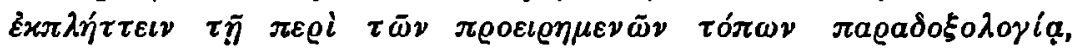

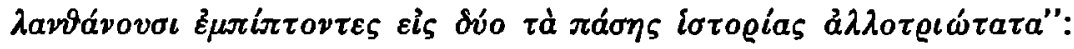
„,eenerzijds stellen zij Hannibal voor als onovertroffen in koenheid zoowel als in voorzichtigheid, anderzijds stellen zij den overtocht over de Alpen als zoo moeilijk voor, dat hij goden en godenzonen als helpers en gidsen noodig heeft". Zooals Polybius boven den naam van Cato-Hemina verzweeg, verzwijgt hij hier dien van Silenus: dat deze bedoeld is, blijkt uit Cicero, De Div. I 24, 49:

I) Untersuchungen zur Geschichte des Zweiten Pun. Kriegs. Sitzungsber. der Kön. Pr. Akad. I913, p. 696. 
„Hoc item in Sileni, quem Coelius sequitur, Graeca historia est (is autem diligentissume res Hannibalis persecutus est): Hannibalem, cum cepisset Saguntum, visum esse in somnis a Jove in deorum concilium vocari; quo cum venisset, Jovem imperavisse, ut Italiae bellum inferret, ducemque ei unum e concilio datum, quo illum utentem cum exercitu progredi coepisse" e.q.s.

Hieruit blijkt, dat ook Silenus als oorzaken van den oorlog moet gegeven hebben:

$I^{\circ}$. Het beleg en de inname van Saguntum (,,cum cepisset Saguntum").

$2^{\circ}$. Het overtrekken van den Ebro. Immers, het ware vrij onnoozel, Juppiter aan Hannibal te laten bevelen Italië te gaan bevechten, als de Romeinen Hannibal den oorlog reeds verklaard hadden ${ }^{1}$ ).

Nog een derde punt, voor ons onderzoek van gewicht, kunnen we aan Polybius ontleenen en als afkomstig van de vóór-Polybiaansche groep aanwijzen. Als Polybius III 9, 6 zijn zienswijze over de oorzaken van den oorlog heeft gegeven, volgt III II als bewijs van den wrok van Hamilcar het verhaal van den eed, dien hij Hannibal

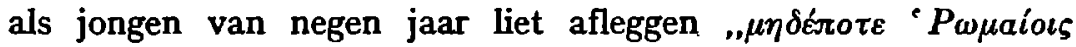
$\varepsilon \dot{\nu}$ ớ $\sigma \varepsilon \iota \nu^{\prime \prime}$. Dat met dit verhaal slechts bewezen kan worden, dat Hamilcar den Romeinen niet welgezind was, maar niet, dat deze stemming nu ook de werkelijke oorzaak van den oorlog was, zal ons later nog bezighouden: hier vragen wij ons af: van wien heeft Polybius dit verhaal?

Hannibal zou de geschiedenis verteld hebben aan Antiochus van Syrië in I93 v. Chr.: zij moet dus reeds lang vóór Polybius in de litteratuur bekend zijn geweest. Groag ${ }^{2}$ ) merkt op „Wie man sieht, befindet die Geschichte sich in der recht bedenklichen Umgebung einer hellenistischen Geschichtsnovelle, der es an inneren Unwahrscheinlichkeiten nicht fehlt". Livius geeft het verhaal tweemaal; in XXI, I, 4 begint hij met „Fama est etiam"; in XXXV I9, 3 luidt

I) Terecht merkt Norden (Ennius und Vergilius, p. 1 I $8{ }^{1}$ )) op: ,Dic Fiktion zeigt uns den Silenos ganz in Fahrwasser der hellenistischen Historiographie: vgl. den Traum Alexanders, seine Bewillkomnung durch Herakles, u.s.w., Arrian II 18, I." De beteekenis van den droom is veelvuldig besproken: men zie o.a. Meyer, Sitzungsber. p. 7 r2-7I4.

2) „Hannibal als Politiker", p. 20. Anm. r. 
het, zeer dicht aansluitend bij de lezing van Polybius „Pater Hamilkar” inquit (sc. Hannibal) „Antioche, parvum admodum me, cum sacrificaret, altaribus admotum iureiurando adegit $n u m q u a m$

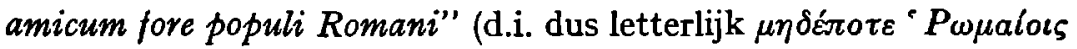

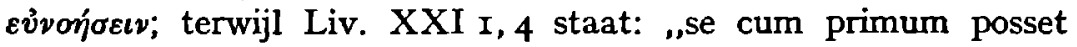
hostem fore populi Romani"). We kunnen hier niet ingaan op het probleem der bronnen van Livius XXI ${ }^{1}$ ); als een der algemeen erkende resultaten in deze zoo dikwijls behandelde kwestie wordt algemeen aangenomen, dat Livius o.a. hier Coelius Antipater volgt, over wien het Cic. de Divin. I 24, 49 heet: „Hoc item in Sileni, quem Coelius sequitur, Graeca historia est". Het vermoeden ligt dus voor de hand, dat Livius in XXXV, I9 de positieve melding van Polybius volgt, die het verhaal wel in positieven zin moest geven, daar het moest dienen als bewijs - maar dat in Livius XXI, I via Coelius nog de vage voorstelling doorklinkt, die Silenus aan zijn werk gegeven had ${ }^{2}$ ). Men vergelijke slechts, wat Heinze (Vergils epische Technik, p. 236-237) zegt over de inleiding „fama est": „So hatte Catull, gewisz in engem Anschlusz an sein Griechisches Original, sein ganzes Epyllion nicht als Erzählung, sondern als Wiedererzählung gegeben; so führt Horaz gern Beispiele aus Mythus und Geschichte als „Bericht" ein; so hatte Vergil selbst das Aristaeusepyllion am Schlusse seiner Georgica mit einem „ut fama" eingeleitet (IV 318, vgl. I26). Auch in der Aeneis beruft er sich nicht selten auf das, was er gehört hat, was gesagt oder berichtet wird, was fama ist; ja, er läszt keinen Zweifel darüber, dasz die Muse, die er über besonders schwierige und dunkle Punkte um

I) Men zie over deze kwestie de uitgebreide litteratuur Niese-Hohl: „Grundriss der Röm. Geschichte"', p. roo. Anm. I. Hoe onzeker alles nog is, tlijkt wel uit het feit, dat A. Klotz aan zijn verhandeling: ,,Appians Darstellungen des zweiten Punischen Krieges" (Paderborn r936) den ondertitel meegeeft: "Eine Voruntersuchung zur Quellenanalyse der dritten Dekade des Livius". 2) Dat Polybius het verhaal mondeling vernomen zou hebben in den kring der Scipionen (Meltzer II, p. 399) is èn om den aard van het verhaal èn om de tusschenruimte van \pm 40 jaar niet waarschijnlijk. Het moest immers ook buiten den Scipionenkring bekend zijn geworden en zou dan toch eerder in de litteratuur opgenomen zijn. Men zie ook Klotz (o.l. p. I9): „Die Geschichte vom Eid des neunjährigen Hannibal gebt in letzter Linie auf ihn selbst zurück. Sie kann in die Litteratur nur von einem Geschichtsschreiber eingeführt sein, der zu ihm unmittelbare Beziehungen gehabt hat, d.h. durch Silen oder Sosylos". 
Belehrung bittet, nichts anders ist als eben jene fama: für deren Richtigkeit er so einerseits die eigne Bürgschaft ablehnt, während er andererseits dem Verdachte eigener Erfindung vorbeugt. D a s $z$ diese $f$ ama weit entfernt ist von unbedingter Zuverlässigkeit, verhelt er sich und seinen Lesern $n$ icht..." (spatieering van ons).

Samenvattend constateeren we dus voor de groep Chaereas, Sosylus, Silenus, Cato en Cassius Hemina, dat ze

$I^{\circ}$. Als oorzaken van den tweeden Punischen oorlog opgaven:

a. Het beleg en de inname van Saguntum door Hannibal,

$b$. De schending van het Ebro-verdrag.

$2^{\circ}$. Dat minstens nog Silenus de wrok van Hamilcar vermeldde, maar niet als oorzaak van den oorlog; deze beteekenis gaf Polybius eraan.

\section{B - FABIUS PICTOR EN ENNIUS ${ }^{1}$ )}

Het standpunt van Fabius Pictor, die als senator en dus als deelnemer aan al wat vóór, tijdens en direct na den tweeden Punischen oorlog gebeurd was, geacht werd een autoriteit van den eersten rang te zijn (waartegen Pol. III 9 dan ook meent te moeten waar-

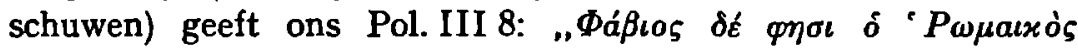

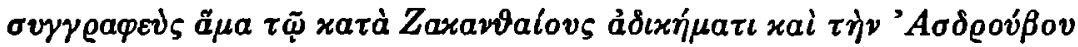

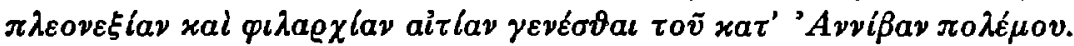

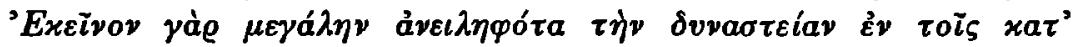

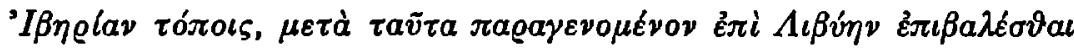

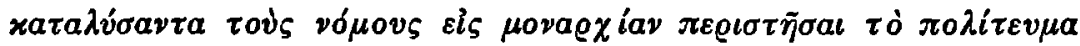

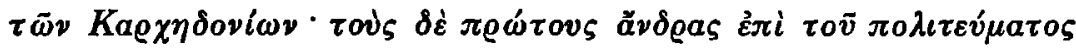

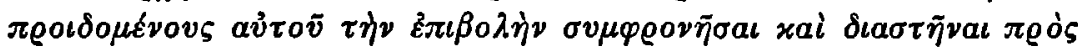

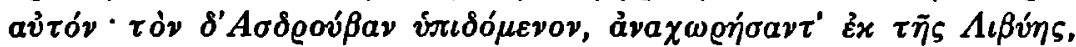

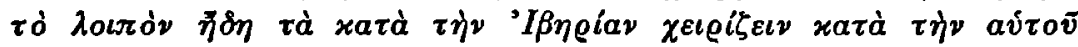

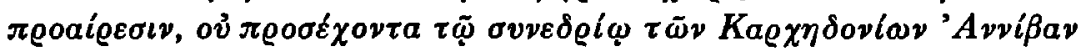

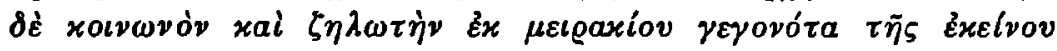

I) Over L. Cincius Alimentus zie p. 22. Vermoedelijk heeft bij bet werk van Fabius naar zijn smaak omgewerkt en voortgezet; détails kan hij gecorrigeerd hebben. Liv. XXI 38,2 „L. Cincius Alimentus, qui captum se ab Hannibale scribit": hier klinkt de toon door van iemand, die in een polemiek

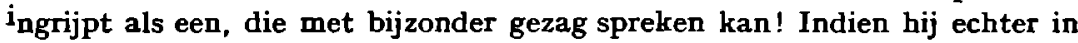
onze kwestie een afwijkend standpunt had ingenomen, zouden we er vermoedelijk bij Polybius of latere schrijvers wel iets van vernomen hebben. 


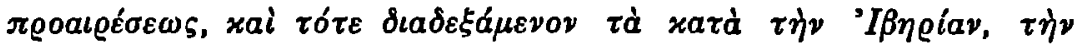

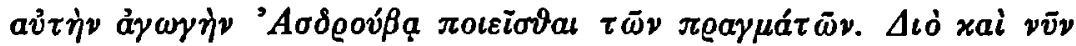

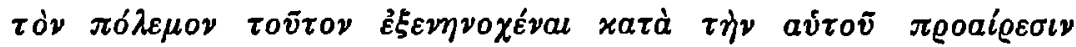

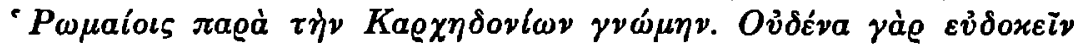

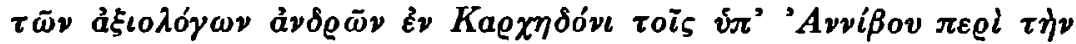

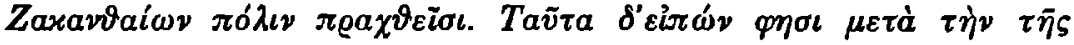

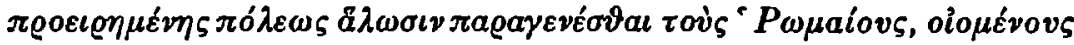

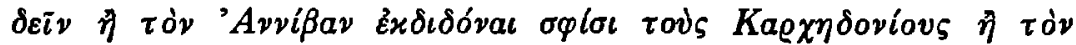

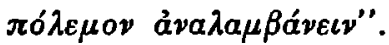

Fabius geeft dus als oorzaken $I^{\circ}$. het onrecht jegens Saguntum; $2^{\circ}$. De hebzucht en de heerschzucht van Hasdrubal, op Hannibal van jongs af aan overgebracht. Als bewijs voor dit tweede punt wordt gegeven het feit, dat de oorlog tegen den zin van de autoriteiten te Karthago werd gevoerd.

Dat dit laatste niet waar is, blijkt uit het feit, dat Karthago gedurende geheel den oorlog Hannibal heeft gesteund, en hem zelfs na het verlies van den oorlog nog de leiding van den staat heeft opgedragen, totdat de Romeinen hem noodzaakten te vluchten. Wat aan deze argumenteering van Fabius ten grondslag lag, was wel het bestaan van een anti-Barcinische fractie in den Karthaagschen senaat onder leiding van Hanno ${ }^{1}$ ). Dat hij zijn bewering niet uit deducties of apriorismen afleidde, maar dat hij deze opvattingen had van de Karthaagsche onderhandelaars na den tweeden Pun. oorlog, blijkt uit Pol. XV I, 7. 8; 17, 3; Livius XXX, 16, 5-6; 22, I-3; 42, 12. Fabius was immers als senator getuige van dit alles geweest. Maar ook hij moet, evengoed als de geheele senaat, beter geweten hebben omtrent den werkelijken gang van zaken: hij had evengoed als welke Romein ook de volledige medewerking ondervonden van de Karthaagsche regeering voor Hannibal; hij wist ook, dat Hannibal, ondanks het verlies van den oorlog, de voornaamste posten bezette, terwijl in andere gevallen de Karthagers hun ongelukkige veldheeren zoo wreed plachten te straffen. De Romeinsche senaat hechtte blijkens de langdurige en herhaalde onderhandelingen, waarbij zelfs het eerste gezantschap als onwaardig werd teruggestuurd (Liv. XXX 22 en 23, I) geen onvoorwaardelijk geloof aan de beweringen der Karthaagsche woordvoerders en ging geenszins

1) Men zie o.a. Täubler: „Die Vorgeschichte”, p. 7 I-72 en Groag: , Hannibal als Politiker", p. 28, $4^{83}, 68$. 
accoord met de conclusies, die de Karthagers uit hun beweringen trokken, om den nieuwen vrede wederom te stellen als bij het verdrag met Lutatius ${ }^{1}$ ).

Waarom heeft dan Fabius Pictor hun toenmalige beweringen zonder meer overgenomen als verklaring voor het ontstaan van den oorlog?

Alleen omdat Fabius niet alleen de schuldvraag moest behandelen, maar ook het lot van Saguntum: hij moest aan zijn Grieksche lezers, voor wie hij zijn werk schreef als propaganda voor de Romeinsche politiek, een verklaring geven, waarom Rome zijn bondgenooten niet geholpen had. Volgens Fabius had de senaat door het eerste gezantschap laten informeeren te Karthago en, gezien de stemming aldaar, geen gevaar geducht voor Saguntum. Zoodoende lag alle schuld aan het ontstaan van den oorlog bij Karthago, en was tevens verklaard, waarom Rome lijdelijk had toegezien, hoe een bevriende stad werd vernietigd ${ }^{2}$ ). Polybius weerlegt het standpunt van Fabius door er op te wijzen, dat, als Hannibal werkelijk tegen den zin van de autoriteiten had gehandeld, deze eenvoudigweg hadden moeten toestemmen, toen de Romeinen zijn uitlevering eischten na den val van Saguntum. Ook overigens gaat de redeneering van Fabius niet op: het deed voor de Saguntijnen in hun nood weinig ter zake, of Hannibal hen met of zonder de instemming zijner regeering belegerde: voor Rome was het, indien men er althans het recht en dus den plicht toe had, zaak om hun bondgenooten te helpen - zeker, indien Hannibal door Karthago gedesavoueerd werd.

Het is niet te verwachten dat Ennius iets anders deed dan, wat een schriftelijke bron vóór hem gegeven had, omwerken en geschikt maken voor zijn epos: geen historicus is hij immers, maar dichter ${ }^{3}$ ). Bekend is, dat Ennius gestorven is in $169 \mathrm{v}$. Chr.: onmogelijk is dus, dat de vervalschingen over de Karthaagsche verdragsschendingen

I) Liv. XXX 22, 2-4: , senatui ac populo Carthaginiensi, si quis vere aestimet, foedus ad eam diem inviolatum esse cum Romanis. Itaque, nihil aliud sibi mandatum esse uti peterent, quam ut in ea pace, quae postremo cum C. Lutatio facta esset, manere liceret".

2) Men zie Gelzer: „.Römische Politik bei Fabius Pictor" (Hermes 68 (1933),

p. I63), die de bewering van Fabius weer tot de zijnc maakt.

3) Geschichte der Röm. Litteratur. Schanz-Hosius I, p. 90 ssqq.; E. Norden, Ennius und Vergilius, p. ${ }_{4} \mathbf{8}$. 
op Sardinië in 235, 234 en 233 v. Chr., door Täubler (overigens geheel ten onrechte) o.l. p. 40 aan Cato toegeschreven, volgens dienzelfden Täubler reeds, aan Cato ontleend, bij Ennius te vinden zouden zijn: Cato begon immers ongeveer I68 v. Chr. met zijn werk $^{1}$ ). Daar Ennius voor den Gallischen oorlog van 225 tot 222 v. Chr. zeker Fabius volgt ${ }^{2}$ ), is niet te zien, waarom hij voor den tweeden Pun. oorlog van schrijver veranderd zou zijn: wien had hij trouwens moeten nemen tenzij Fabius? De zienswijze van Chaereas, Sosylus en Silenus strookte niet met de zijne, en Cato moest zijn werk nog schrijven!

Is uit de fragmenten van Ennius nog iets te concludeeren voor zijn opvatting van het vraagstuk, dat ons bezighoudt? Ed. Norden heeft ${ }^{3}$ ) getracht klaarheid te brengen: daar het bij eerste beschouwing allen schijn heeft, dat hij ook voor de beschrijving van den tweeden Punischen oorlog fraaie ontdekkingen deed, en hij veel erkenning vond 4 , maar nog geen geheele weerlegging, moge zijn redeneering hier getoetst worden aan onze tot nu toe gevonden gegevens.

Ennius heeft volgens Norden voor den aanvang van den tweeden Punischen oorlog en van de daaraan voorafgaande oorlogen in Sardinië, Italië en Illyrië een pax-scene ingevoerd, die later door Vergilius in Aeneis VII geimiteerd is: in $235 \mathrm{v}$. Chr. worden de deuren van den tempel van Janus plechtig gesloten, omdat Rome nergens ter wereld oorlog behoeft te voeren. Maar dra gaan de poorten van den tempel van Janus weer open, en wel op drijven van Juno, die niet kan berusten in de nederlaag, door haar geliefde Karthago geleden. Naar aanleiding hiervan heeft er een godenvergadering plaats: Juppiter laat zich door Juno verbidden om aanvankelijk niet tusschenbeide te komen: zoo worden de overwinningen van Hannibal gedurende de eerste jaren episch gemotiveerd (o.1. p. 52-56). In 235 sloot consul T. Manlius Torquatus de Janus-deuren: in hetzelfde jaar moesten ze echter weer open, om eerst door Keizer Augustus weer gesloten te worden. Pag. 57-58

I) Schanz-Hosius o.1. p. 188 .

2) Norden, o.1. p. 149.

3) Ennius und Vergilius.

4) Pasquali in de Gött. Gel. Anz. 19r5, p. 593-6ro; P. Jahn in de Berl. Philol. Wochenschr. 1916, p. 198-204; Täubler: „Die Vorgeschichte”, p. 37 ssqq. 
vermeldt Norden uit Orosius IV I3, I de wraakzucht van Hamilcar, de anti-Romeinsche kuiperijen der Karthagers op Sardinië: „Polybios sagt (III Io) dasz die römische Okkupation Sardiniens als der entscheidende Grund für den Ausbruch des neuen Krieges zu betrachten sei. Diese Auffassung des Historikers wird bestätigt durch die des Dichters, der den abermaligen Ausbruch der Zwietracht zwischen den beiden Völkern von der die sardischen Verhältnisse begleitenden Oeffnung des Janustempels an datiert. Der Zeremonie der Oeffnung im Jahre 235 gingen, wie wir soeben sahen, dringende Gesandtschaften der Karthager mit der Bitte um Frieden voraus; der letzten dieser Gesandtschaften wurde er endlich gewährt".

Jammer voor de mooie combinatie van Norden is het feit, dat de berichten bij Orosius, zooals we later zullen zien, op vervalschingen van latere annalisten berusten: waren zij den historicus Polybius bekend geweest, dan had deze den eed van Hannibal niet noodig gehad als bewijs voor zijn Sardinie-these! Maar nog erger is, dat de "Bestätigung des Dichters" aan het constateeren van den „Historiker" voorafgal: in $169 \mathrm{v}$. Chr. sterft Ennius, en in ${ }^{6} 67$ wordt Polybius pas naar Italië gedeporteerd. Hiermee vervallen alle conclusies, die Norden en anderen uit dezen opzet getrokken hebben: dat Ennius iets anders of iets meer gaf dan Fabius Pictor, is onbewezen en onwaarschijnlijk.

\section{C - POLYBIUS}

$\mathrm{Na}$ de oorzaken, door de schrijvers vóór hem gegeven, vermeld en verworpen te hebben, gaat Polybius als volgt verder: (III 9, 6).

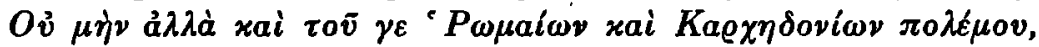

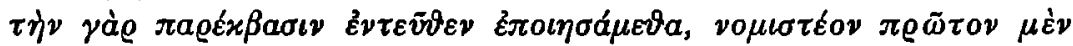

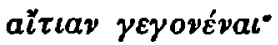

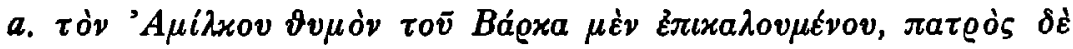

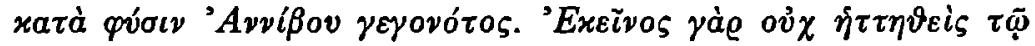

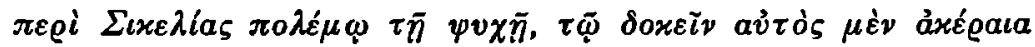

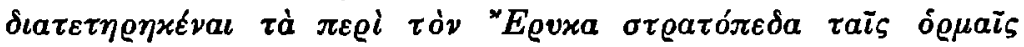

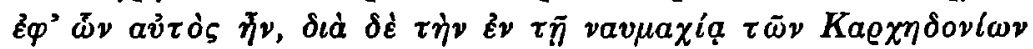

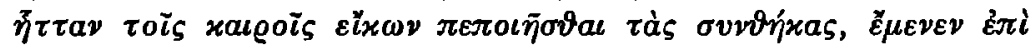

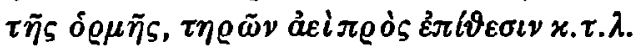

In Boek III Io, 4, na den roof van Sardinië verhaald te hebben, gaat hij voort: 


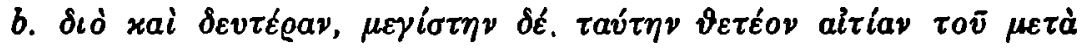

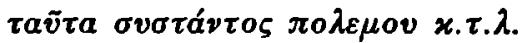

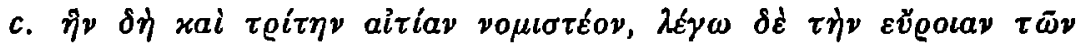

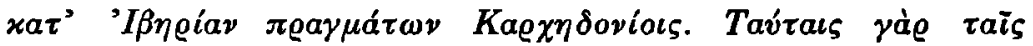

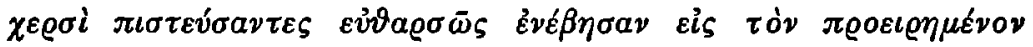
$\pi \delta \dot{\lambda \varepsilon \mu o v . "}$

Dat Hamilcar, hoewel tien jaar vóór het uitbreken van den oorlog gestorven, het meeste zou hebben bijgedragen aan het ontstaan ervan, zou Polybius met veel argumenten kunnen bevestigen: hij wil zich echter beperken tot één bewijs: III II verhaalt hij den eed, dien Hannibal ten overstaan van Hamilcar moest afleggen

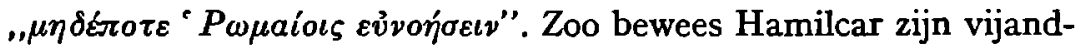
schap (III I2, 2-3); Hasdrubal prentte hij diezelfde verbittering in, maar deze stierf te vroeg, dan dat hij zijn vijandschap had kunnen

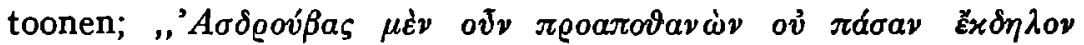

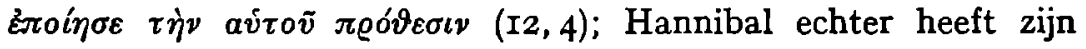
vijandschap maar al te zeer bewezen (ibidem).

Het is duidelijk, dat Polybius onder oorzaken verstaat: de innerlijke drijfveeren van den mensch, die de uitwendige daden veroorzaken. Zijn opvatting licht hij toe met twee voorbeelden: de oorzaak van den oorlog onder Alexander den Grooten tegen de Perzen was: primo: het bewustzijn der Grieken van hun militaire overmacht, ontstaan door den tocht der tienduizend, en den veldtocht van Agesilaus in Klein-Azië; secundo, de verwachting op rijken buit. Als voorwendsel diende: wraak der Grieken op de Perzen wegens het aangedane onrecht; het begin was: de overtocht van Alexander naar Klein-Azië. Tweede voorbeeld: de oorzaak van den oorlog tusschen Antiochus van Syrië en de Romeinen was de toorn der Aetoliers om de behandeling, hun door de Romeinen na den tweeden Macedonischen oorlog aangedaan; als voorwendsel gold: de bevrijding der Grieken; begin was de overvaart van Antiochus naar Demetrias. In deze overigens zeer aanvaardbare onderscheiding ${ }^{1}$ ) missen we slechts: de aanleiding. Al zouden we dus de motiveering van den tweeden Punischen oorlog van Polybius overnemen, zouden we de volgende wijziging moeten aanbrengen: oorzaak: de haat der Barciden; aanleiding: het conflict om Saguntum; begin:

I) Waarmede niet gezegd wordt, dat we met de toepassing van Polybius in de twee voorbeelden accoord gaan. 
de oorlogsverklaring en de toebereidselen tot den wederzijdschen aanval bij Karthagers en Romeinen. Over een voorwendsel in dezen oorlog spreekt Polybius nog niet: Hannibals parool in Italië, dat hij de Italische volkeren kwam bevrijden (Pol. III 77, 4-6), kon in deze phase nog geen rol spelen.

\section{D - DE OVERLEVERING NA POLYBIUS}

Het is welhaast een gemeenplaats geworden om over de onbetrouwbaarheid der annalisten te spreken. Het is slechts volledigheidshalve, dat we, wat er aan schrijvers na Polybius nog voor ons bewaard bleef, in dit onderzoek betrekken. Blijken zal, dat geen schrijver ons nog iets nieuws te bieden heeft; hun eigen aandeel en dat van de tusschen-bronnen bestaat in het contamineeren en overdrijven van de boven vermelde gegevens.

Cornelius Nepos ${ }^{1}$ ) geeft de oorzaak volgens Polybius: Vita Hamilc. I, 4 ,ut statim mente agitaret, si paulum modo res essent refectae, bellum renovare Romanosque armis persequi . . . "' Ibidem 4, 2: huius (sc. Hamilcaris) perpetuum odium erga Romanos maxime concitasse videtur secundum bellum Punicum". Vita Hannib. 2, 2-6 staat de eed, in Polybiaanschen trant: ,iurare iussit numquam me in amicitia cum Romanis fore". Niet Polybiaansch is Vita Hamilc. c 3, 2: de onzedelijke verhouding tusschen Hamilcar en Hasdrubal en c. 3, 3 de beschuldiging, dat Hasdrubal de aloude zeden der Karthagers door omkooperij bedorven zou hebben.

De traditie van Fabius Pictor wordt voortgezet door Diodorus Siculus (Dindorf-Müller XXV): de scherpe overdrijvingen wijzen er op, dat Diodorus hier niet Fabius zelf afschreef ${ }^{2}$ ): „Hamilcar deed tijdens den eersten Punischen oorlog en den Afrikaanschen

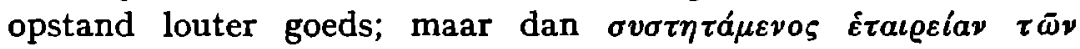

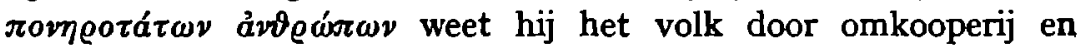
demagogie zoo te bewerken, dat hij het opperbevel over Libye krijgt (XXV 8); over den wrok van Hamilcar wordt niets vermeld. Specifiek Fabiaansch is de heerschzucht van Hadrubal, maar men leze de overdrijving (XXV, 12): Hasdrubal wreekt den ondergang

I) In Marouzeau's „Dix années de bibliographie classique”, Parijs Ig2 7 p. 253 wordt in een kort résumée van een artikel van Salac over de bronnen van Nepos (Listy Filol. r922) Polybius als een der bronnen vermeld.

2) Hultsch, Pauly-Wiss. R. E. V, p. 688 ssqq. 


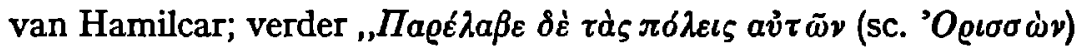

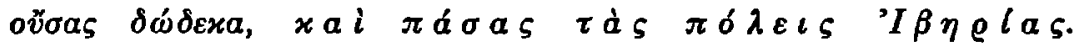

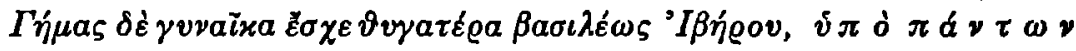

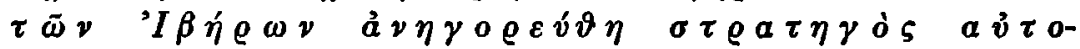

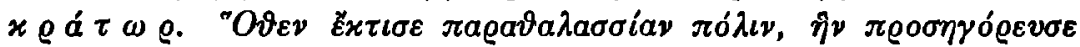

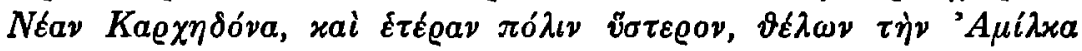

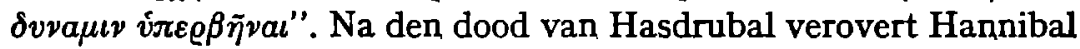

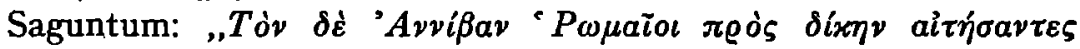

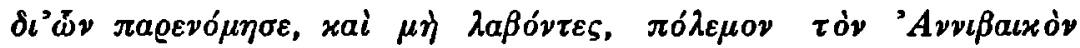

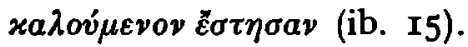

Een zeer nauw verwante lezing geeft Appianus ${ }^{1}$ ) (Iber. 4-I3), maar met nog fellere overdrijvingen: de oorlog ontstaat hier niet meer wegens schending van het Ebroverdrag, maar om de schending van het verdrag, gesloten na den eersten Pun. oorlog (o.1. c. 4); was bij Diodorus Hamilcar nog tot na den Afrikaanschen oorlog onberispelijk, hier wordt zijn overgang tot omkooperij en demagogie verklaard met het feit, dat hij schuldig was aan het uitbreken van den opstand der huurlingen en het verlies van Sardinië(!): zooals bij Diodorus wordt de aanklacht van corruptie, die bij Nepos nog slechts op Hasdrubal sloeg, teruggeschoven op Hamilcar. $\mathrm{Na}$ zijn dood benoemen de Karthagers, belust geworden op de winsten, die Spanje opleverde, Hasdrubal, die het befaamde Ebroverdrag afsluit (c. 7); ook deze bedrijft demagogie en omkooperij, en als, na zijn vermoording, de antibarciden te Karthago hun tegenstanders voor het gerecht willen dagen en willen dwingen de steekpenningen aan den staat terug te geven, veroorzaakt Hannibal (wiens benoeming tot opperbevelhebber intusschen door den senaat was goedgekeurd, en die, o wonder! wist dat de anti-Barcinische meerderheid in den senaat ook hem ten val zou brengen) om de Saguntijnen den oorlog met Rome: in zulke moeilijkheden zullen zijn medeburgers geen tijd of kans voor processen hebben (c. 9).

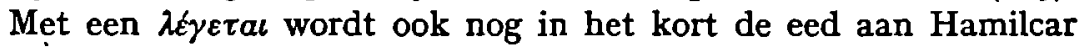
vermeld, echter zonder eenige verdere toespeling op Hamilcars

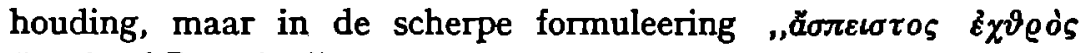

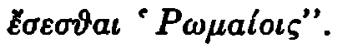

r) Zijn annalistische bron is nauw verwant aan die van Diodorus, maar niet identiek: zie Hultsch o.1. A. Klotz o.l. geeft als tusschen-bronnen Valerius Antias en Timagenes, echter zonder positieve bewijzen. 
Livius XXI, c. I-5 is in de opgave der oorzaken weer geheel Polybiaansch: c. I, 4 de eed van Hannibal, ib. 5 de verbittering van Hamilcar om Sicilië en Sardinië, waarbij het juiste inzicht van Hamilcar in de hopelooze situatie (Pol. I 62 en III 9, 7) omgewerkt wordt tot het bekende "Siciliam nimis celeri desperatione rerum concessam" (c. I, 5). Hasdrubal is de diplomaat; even klinkt de Fabiaansche traditie door: ,medius Hasdrubal inter patrem ac filium octo ferme annos imperium obtinuit, flore aetatis, uti ferunt, primo Hamilcari conciliatus, gener inde ob aliam indolem profecto animi adscitus ${ }^{1}$ ), et quia gener erat, factionis Barcinae opibus, quae apud milites plebemque plus quam modicae erant, haud sane voluntate principum in imperio positus'. Hannibal, aan het bewind gekomen, begint direct met de uitvoering van zijn plannen: c. 5 is Polybius III 14, 9-ro: Hannibal onderwerpt eerst geheel Spanje tot aan den Ebro, en valt dan Saguntum aan, om daardoor den oorlog met Rome uit te lokken.

Over Cassius Dio (Zonaras VIII 22, p. I96-I99 Melber) spraken we reeds pag. 2I ssqq.: we zagen, dat hij in dit caput nog de vóórPolybiaansche meening had van Cato. Hiermee wil niet gezegd zijn, dat hij in zijn geheele verhaal teruggaat op Cato: uit Zonar. VIII I8, waarin het Romeinsch-Karth. conflict om de z.g. vergrijpen jegens de Romeinsche kooplui en de Karthaagsche intriges op Sardinië behandeld worden, blijken duidelijk toevoegsels van latere annalisten ${ }^{2}$ ). Wel wordt Zon. VIII I7 gesproken over den haat van Hamilcar - dat deed immers reeds Silenus - maar als oorzaak van den oorlog vinden we den eed hier niet vermeld.

Samenvattend zien wij dus drie groepen:

Groep I: Als oorzaken gelden: de inname van Saguntum en de schending van de Ebro-grens.

Auctores: Chaereas-Sosylus-Silenus; Cato en vermoedelijk Cassius Hemina; Cassius Dio (bij hem met latere falsificaties uitgebreid).

I) Hier klinkt duidelijk polemiek door tegen de lezing, zooals wij die nog bij Nepos Vita Hamilc. 3, 2 kennen: ,quo factum est, ut a praefecto morum Hasdrubal cum eo (sc. Hamilcare) vetaretur esse. Huic ille filiam suam in matrimonium dedit, quod moribus eorum non poterat interdici socero genero'".

2) Zie Hoofdstuk III. 
Groep 2: Als oorzaken gelden: De hebzucht en de heerschzucht van Hasdrubal en Hannibal; het onrecht jegens Saguntum. Auctores: Fabius Pictor, en (met uitbreidingen) Diodorus en Appianus.

Groep 3: Als oorzaken gelden: De wrok van Hamilcar over het verlies van den eersten oorlog en den roof van Sardinië. De macht, in Spanje verworven.

Als begin geldt: de inname van Saguntum en de overschrijding van den Ebro.

Auctores: Polybius; met toevoegsels uit Groep 2: C. Nepos en Titus Livius.

$$
\text { 2 - DE SCHULDVRAAG VAN 2I9-2I8V.CHR. }
$$

Gaven we p. 31 Polybius gelijk in zijn opvatting, dat we als oorzaken slechts de innerlijke drijfveeren mogen aanvaarden, die de uiterlijke daden doen stellen, dan zijn de schending van het Ebro-verdrag en de inname van Saguntum inderdaad geen oorzaak, maar slechts de aanleiding tot den oorlog. Het zijn dus deze twee feiten, die we hier moeten onderzoeken.

Bij dit onderzoek zij Polybius III 30 punt van uitgang. Hij memoreert, hoe de Romeinen op verzoek der Saguntijnen zelf een twist in Saguntum beslecht hebben, en geeft dit als bewijs, dat de Saguntijnen zich in de hoede der Romeinen gesteld hadden; zelfs

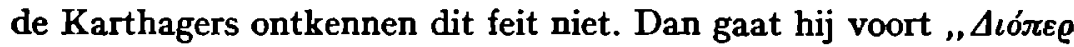

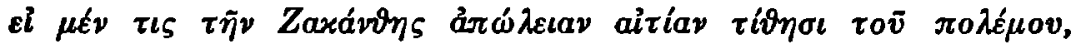

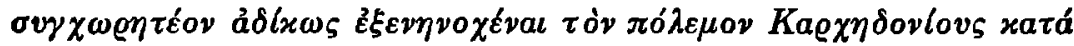

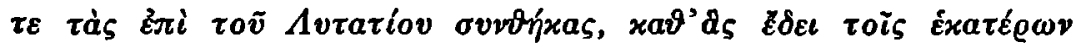

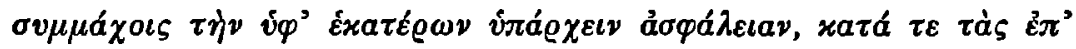

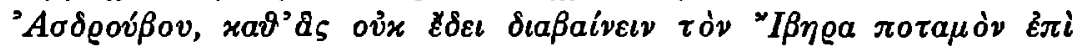

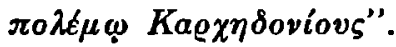

Aan Hannibal wordt dus dubbele verdragsschending ten laste gelegd: schending van het verdrag, met Lutatius in 24I gesloten; en van het Ebro-verdrag, met Hasdrubal als Karthaagsch veldheer door de Romeinen aangegaan.

De motiveering inzake het verdrag van $24 \mathrm{I}$ is duidelijk: beide partijen garandeerden aan elkaars bondgenooten onaantastbaarheid, en nu was Saguntum, bondgenoot van Rome, met geweld 
genomen. Grootere moeilijkheden biedt de motiveering inzake het Ebro-verdrag: laten we eerst den inhoud van dit verdrag bepalen.

Polybius geeft II I3, 7 als eenige bepaling, dat de Karthagers

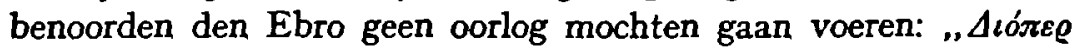

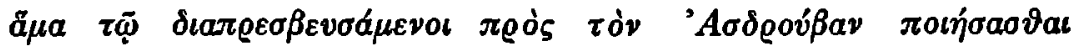

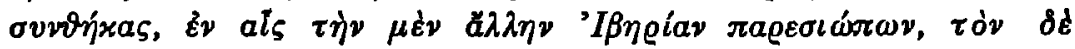

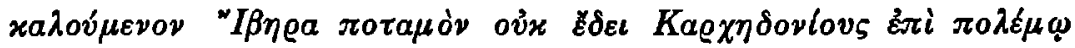

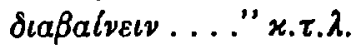

Livius XXI, 2, 7: Cum hoc Hasdrubale, quia mirae artis in sollicitandis gentibus imperioque suo iungendis fuerat, foedus renovaverat populus Romanus, ut finis utriusque imperii esset amnis Hiberus, Saguntinisque mediis inter imperia duorum populorum libertas servaretur".

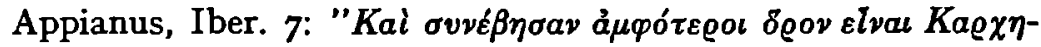

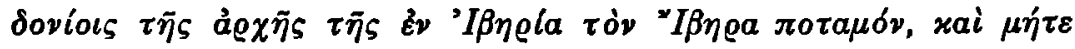

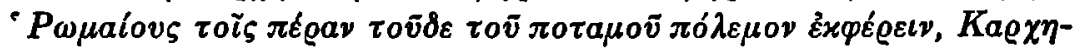

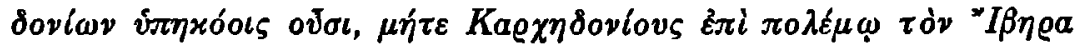

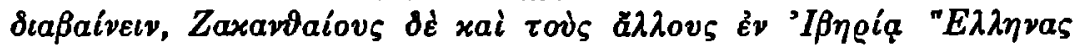

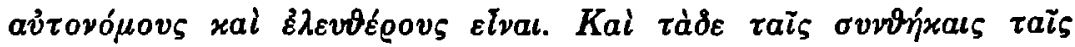

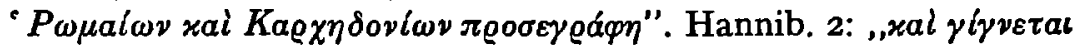

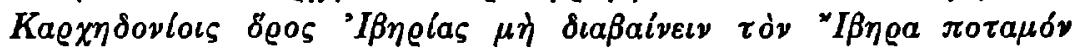

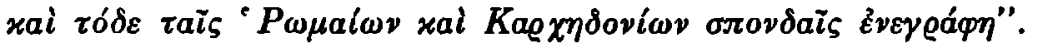

Cassius Dio (Zonaras VIII 2I, p. I94 Melber): „Oj̃ ou yà $\varrho$ (sc. de

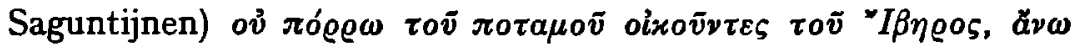

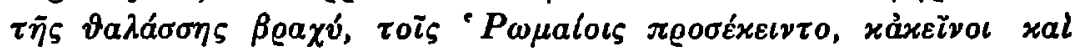

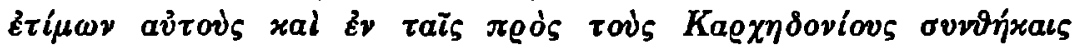

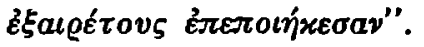

Zooals men ziet, ruime verscheidenheid, waar toch hoogstens ééne lezing de juiste kan zijn. Daar we slechts werken hebben van schrijvers, die den Romeinen welgezind waren, en geen enkele van hen verdacht kan worden ten gunste van de Karthagers vervalschingen te hebben gepleegd, vinden we hierin een criterium om latere toevoegsels of vervalschingen te onderscheiden.

Polybius geeft den kortsten inhoud; bovendien noemt hij het verdrag een vriendschappelijke overeenkomst van Rome met den

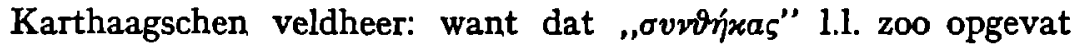
moet worden, blijkt uit III I5, 5 en III 2I, I, waar Polybius telkens

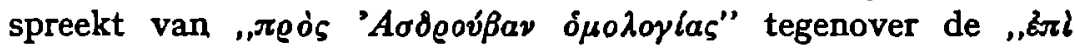




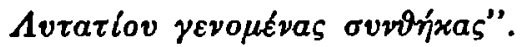

In de discussies in den Karthaagschen senaat met het Romeinsch gezantschap is de rechtsgeldigheid juist op grond van dit feit betwist: daarom zijn duidelijke vervalschingen: bij Livius ,reno-

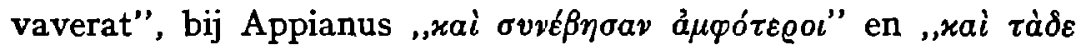

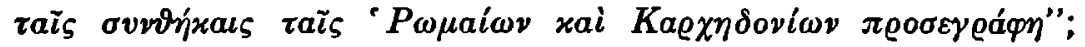
als $\mathrm{h}$ e $\mathrm{r} \mathbf{n}$ i e u w d verdrag of als toevoegsel aan het verdrag van 24I kon de rechtsgeldigheid niet betwist worden.

Rest nog de clausule over de Saguntijnen bij Livius en Cassius Dio, bij Appianus zelfs uitgebreid tot alle Grieken in Spanje. Polybius heeft deze clausule niet, en zijn formuleering sluit zelfs

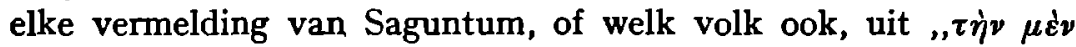
$\alpha \lambda \lambda \eta \nu$ 'I zijn niet-vermelden van Saguntum juist zijn: zijn streven is, om inzake de aanleiding tot den oorlog de schuld der Karthagers te bewijzen: hoe dom ware het dan, de aanwezige clausule te verzwijgen, want daarmee had hij direct en onweerlegbaar het ongeoorloofde van den aanval op Saguntum aangetoond; noodig ware dan nog slechts de discussie geweest, of het verdrag rechtsgeldig was ${ }^{1}$ ). Verbreking van het Ebro-verdrag kon om den aanval op Saguntum alleen niet ten laste gelegd worden: daarom zien we bij Livius de waarborg van volledige vrijheid voor Saguntum, idem bij Cassius Dio, terwijl Appianus Saguntum kort en goed ten

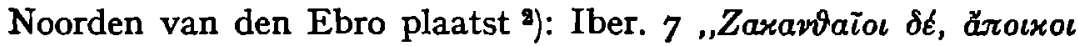

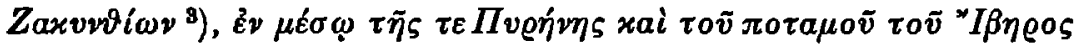

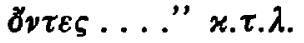

Hoe is het nu mogelijk dat Polybius, indien het Ebro-verdrag niets over Saguntum bevatte, in zijn boven geciteerde aanklacht (III 30, 4) uitdrukkelijk zegt: ,de vernietiging van Saguntum door Hannibal is onrechtmatig volgens het Ebro-verdrag, dat den Karthagers militair-ingrijpen ten Noorden van den Ebro verbood?"

I) Tåubler: ,,Vorgeschichte", p. 96-97; ro6; Meyer: „,Sitzungsber." 693 ssqq.; De Sanctis III I', p 429-430; Groag: „Hannibal als Politiker", p. 3I; Kolbe: „Die Kriegsschuldfrage”, p. II.

2) Hieraan voegt hij (Iber. 12 einde) nog de volgende enormiteit toe:

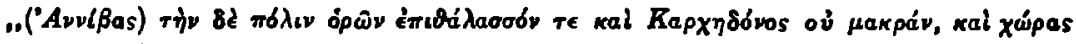

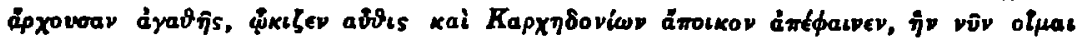

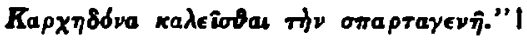

3) Zie over deze „etymologie" Kolbe o.l. p. I2, Anm. 2. 
De eerste indruk is: Polybius denkt, dat Saguntum ten Noorden van den Ebro ligt: hij zou dan dezelfde fout maken als Appianus. Inderdaad is deze veronderstelling ernstig geuit, o.a. door Cuntz, „Polybios und sein Werk", p. 65; laatst door de Sanctis, Storia di Roma III I, p. 429, die uitvoerig de kwestie bespreekt. „Le interpretazione erronee del trattato dell' Ebro han generato tra gli antichi, circa la posizione di Sagunto, una confusione inestricabile. Per Appiano 1. cit. (= Iber. 7) non può esservi dubio: è a nord dell' Ebro. E del pari qualche volta per Polibio. Cosi esplicitamente

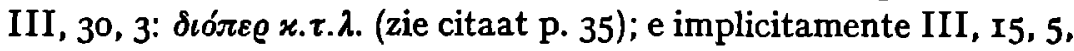

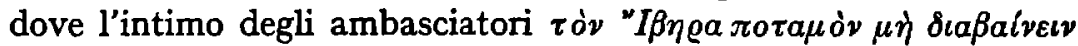
ad Annibale, il quale non pensa che a Sagunto, ha un senso solo se esso contiene il divieto di procedere contro quella città. Deve quindi consentirsi su questo punto con C. Neumann p. 357 n.r. e J. Partsch 'Gött. Gel. Anz.' I88I, p. 334 segg.: e va respinta sia la congettura, in se stessa poco plausible, del Hessebarth p. 9I che

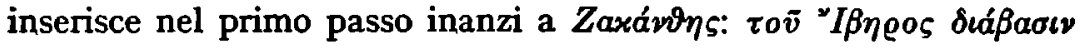

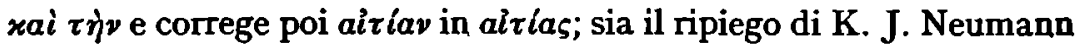
'Litt. Centralblatt' r897, p. I290 che Polibio ivi abbia dato solo un riassunto magro e incompiuto del suo modo di vedere. Non e peraltro da negare che nello stesso libro 14,$9 ; 97,6 ; 98,5$, vi son passi in cui la posizione di Sagunto è indicata senza errore'. Ibidem, na de weerlegging van Cuntz (,.Polybius zou pas op zijn reis in Spanje de juiste ligging van Saguntum hebben leeren kennen en slechts gedeeltelijk zijn werk in dit opzicht hebben verbeterd" hetgeen de Sanctis als volgt weerlegt ,dat door deze verbeterde kennis van Polybius over de ligging van Saguntum Polybius' geheele redeneering over het Ebro-verdrag onhoudbaar werd, zoodat hij zijn werk toch juist in het meest essentieele punt verbeterd zou hebben) en de onmogelijke theorie van Laqueur (Polybius zoo oorspronkelijk de Saguntum-clausule in het Ebro-verdrag genoemd, maar ter vervalsching later geschrapt hebben, zonder evenwel overal nu zijn werk aan deze vervalsching aangepast te hebben $\left.{ }^{1}\right)$ ):

I) Men zie hierover E. Meyer (Sitzungsber. P. 695-696, Anm.), wiens conclusie luidt: „Die Frage, wie es denn in dem Hirn eines solchen Gimpels ausgesehen haben müsse, pflegt man sich ja bei solchen Annahmen nicht vorzulegen”. Men vergelijke ook Kolbe: „Die Kriegsschuldfrage”, p. 12-13. Dezelfde idee als Laqueur had ook reeds in dit punt O. Gilbert (Rom und Karthago, p. 16r). 
„La spiegazione vera è quella additata da C. Neumann, che Polibio, dove parla per proprio conto colloca Sagunto a nord dell' Ebro; dove seque senza pensiero proprio le fonti, lascia trapelare la collocazione giusta che esse attribuivano alla città" (o.l. p. 430).

Het gaat inderdaad niet aan om, zooals Hesselbarth doet, eenvoudigweg door een met niets te verdedigen conjectuur de moeilijkheden uit den weg te ruimen, en den schrijver zoo te laten zeggen, wat men graag ziet; maar om Polybius „senza pensiero proprio" zijn bronnen af te laten schrijven in een kwestie, waarover hij zoo fel debatteert, en zoo hem ervan te betichten, dat hij dicht opeen driemaal Saguntum ten Zuiden en tweemaal ten Noorden van den Ebro plaatst, is hem een even groote gedachtenloosheid toekennen als Laqueur en Cuntz doen, wier theorieën de Sanctis zelf om diezelfde redenen verwerpt.

Meyer $\left.{ }^{1}\right)$ verklaart de polemiek van Polybius als volgt: ,,in Rome werd de schuldvraag nog vaak besproken, en in algemeen gehouden termen zouden als oorzaken opgegeven zijn: het onrecht jegens Saguntum en de overtocht over den Ebro; dit kon reeds zoo geschreven staan. Maar Polybius verwerpt deze redenen met recht, en noemt ze geen aitía, maar ăoxaı, maar „Dadurch ist der Ebrovertrag Hasdrubals in die Vorgänge hineingezogen: hier konnte man die Karthagern auf einen offenkundigen Vertragsbruch festnageln. Wenn dann ein solches Moment erst einmal in die Diskussion hineingeworfen ist, kann es aus ihr nicht wieder verschwinden, solange die betreffende Fragen noch ein aktuelles Interesse haben ... Gewisz ist Polybios zu tadeln, dasz er hier nicht energisch durchgegriffen und den Ebrovertrag in diesen Verhandlungen einfach aus dem Spiel gelassen hat".

Drachmann ${ }^{2}$ ) geeft deze correctie op Meyer: „Het tweede Romeinsche gezantschap, dat uit Karthago terugkeerde, waar het zonder opdracht den oorlog verklaard had, ging via Spanje en Frankrijk en kwam dus zeer laat terug. Toen pas werd in de comitia tot oorlog besloten: maar intusschen was Hannibal op weg naar Italië en over den Ebro: zoo ging de tocht over den Ebro vooraf aan het oorlogsbesluit in de comitia, wat de Romeinsche schrijvers eerst echt als begin van den oorlog opvatten". Drachmann verwerpt

1) Sitzungsber. p. 696-697.

2) Sagunt und die Ebrogrenze, p. r8-21. 
de historiciteit van de mededeeling, dat de gezanten in Spanje en Frankrijk bondgenooten gingen zoeken, maar niet, dat ze erheen gingen! Wel een zonderling gezantschap, dat in Karthago, in strijd met hun opdracht nota bene! den oorlog verklaart, dan zonder reden door vijandelijk gebied (Spanje) en veel gevaarlijk terrein (Gallië, Noord-Italië) reist, waarbij het door de falsarissen-annalisten gevonden motief vervalt, in plaats van langs den aangewezen weg (Sicilië-Italië) direct naar Rome te gaan en het volk te gaan waarschuwen! Bovendien, juist van de "Karthaagsche" schrijvers is bekend, dat zij den Ebro-overtocht als oorzaak gaven: daarmee vervalt de op zichzelf reeds eigenaardige en gewrongen uitleg van het ,,begin van den oorlog". Groag ${ }^{1}$ ) zegt , Mir scheint eher die Erklärung annehmbar, dasz die Quellen gerade in diesen Fragen der Kriegsschuld derart divergierten und zum Teil die historische Wahrheit mit Absicht derart entstellten, dasz Polybios, der mit vorgefaszter Meinung an diese Probleme herantrat, zu keiner vollkommen klaren Formulierung zu gelangen vermochte". Kolbe ${ }^{2}$ ) meent: „Mann kommt in der Tat nicht darum herum, dasz er (sc. Polybius) trotz aller aufgewandten Mühe des Problems nicht Herr geworden ist, welche Rolle der Hasdrubalvertrag in den Verhandlungen vor 219 gespielt hat".

Men ziet, Meyer protesteert tegen de opvatting, dat Polybius 'n zwakzinnige stumper zou zijn, maar komt zelf toch ook ongeveer tot die conclusie, en anderen met hem. Is deze controverse te beslechten? Wij meenen van wel.

In Polybius III 30 spreekt duidelijk uit elk woord polemiek. Deze polemiek richt zich natuurlijk tegen dezelfde schrijvers, wier opinie over de schuldvraag hij vermeld heeft: we noemden die (pag. 34-35) groep één (Chaereas, Sosylus, Silenus, Cato-Hemina)engroep twee (Fabius Pictor c.s.). Groep één gaf als oorzaken: de inname van Saguntum en de verbreking van het Ebro-verdrag: pag. 28-29 zagen we, om welke reden Polybius deze verbreking wel niet geheel verzweeg, maar als de $\chi \dot{\eta}$, geen ait $\boldsymbol{\alpha} \alpha$ betitelde: deze handelwijze verraadt zich nog in het feit, dat nu ook de inname van Saguntum, die ook volgens Polybius' verdere voorstelling zich vóór de oorlogsverklaring afspeelde, als ả $\varrho \chi \dot{\eta}$ optreedt. Groep twee gaf als oorzaak:

I) Hannibal als Politiker, p. 65, Anm. 1.

2) Die Kriegsschuldfrage, p. 15. 
de hebzucht en de heerschzucht van Hasdrubal en het onrecht jegens Saguntum. Polybius geeft echter zijn eigen opvatting van de oorzaken, en bestrijdt dan samenvattend die van zijn voorgangers:

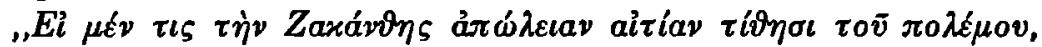

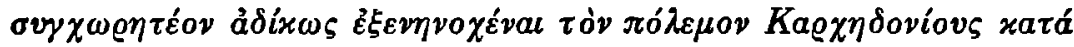

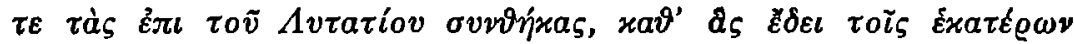

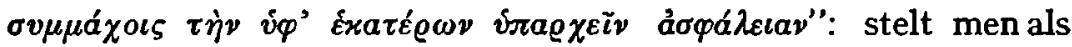
oorzaak het beleg van Saguntum, dan heeft Karthago ongelijk, want als bondgenooten van Rome genoten de Saguntijnen onschendbaarheid krachtens het verdrag van Lutatius;

en dan moest volgen:

Chaereas - Cato - Hemina noemen naast Saguntum de overschrijding van den Ebro als oorzaak, en dan zijn de Karthagers schuldig volgens het verdrag met Hasdrubal, volgens hetwelk de Karthagers den Ebro niet mochten overtrekken". Daar Polybius echter de gegevens van Chaereas-Cato om zeer begrijpelijke redenen verdraaid had, kon hij ze hier niet zonder meer noemen.

Welke overlevering is nu de juiste inzake de aanleiding tot den oorlog, die van groep een, of van groep twee?

In de op pag. 26-27 geciteerde passage geeft Polybius (III 8) voor Fabius als oorzaken op: $I^{\circ}$. Het onrecht jegens Saguntum, $2^{\circ}$. de hebzucht en heerschzucht van Hasdrubal.

Is deze motiveering in feite wel iets anders, dan de helft van wat groep één gaf, n.l. Saguntum als oorzaak?

Het conflict tusschen Hasdrubal en Karthago kon een burgeroorlog veroorzaken tusschen die twee partijen; eventueel kon het na een verloren oorlog den Karthagers ook dienen als excuus tegenover Rome, (waarop de overlevering bij Livius dan ook wijst); maar om er een diepere motiveering in te zien voor het conflict Hasdrubal-Hannibal tegen Rome, is niet logisch. Minstens had dan de overlevering moeten luiden: Hasdrubal-Hannibal namen van de Romeinen, wat ze van de Karthagers niet konden krijgen: en dat staat nergens. In elk geval moeten we de gegevens van Fabius als volgt ontleden:

$I^{\circ}$. De diepere oorzaak is de heerschzucht van Hasdrubal, door dezen ook aan Hannibal ingeprent.

$2^{\circ}$. De aanleiding werd het conflict om Saguntum. 
De schending van het Ebro-verdrag laat Fabius dus weg, evenals Polybius, en om dezelfde reden: de fides colendi socios mocht niet ontkend kunnen worden.

We moeten ons dus houden aan de gegevens, die groep één ons verschaft: Hannibal veroverde Saguntum en verbrak het Ebroverdrag. In welken vorm dit geschiedde, door een formeele daad of slechts door opzegging tijdens de onderhandelingen, is wegens het verzwijgen door Polybius e.a. niet meer te achterhalen.

Wat ging nu aan deze daden van Hannibal vooraf van den kant der Romeinen, waardoor Hannibals optreden verklaard kan worden?

Allereerst doet het eigenaardig aan, dat Polybius aan Hannibal weliswaar den opzet toeschrijft om zoo spoedig mogelijk met Rome in conflict te komen, maar dat ook volgens hem de Romeinen de eersten zijn, die iets ondernemen: tot aan het optreden van het eerste gezantschap der Romeinen viel Hannibal ten opzichte van Saguntum ook volgens Polybius' eigen getuigenis ${ }^{1}$ ) niets te verwijten. Zonder het optreden van het Romeinsche gezantschap ware een actie van Hannibal tegen Saguntum zelfs geen casus belli geweest. We zien dus, dat in de zaak, die Hannibal als middel gebruikt om met Rome in conflict te geraken, het initiatief van de Romeinen uitging; bovendien zou Hannibal in Saguntum blijkbaar geen goed motief tot oorlog gezocht hebben, daar de Romeinsche senaat zelfs na den val van Saguntum nog onzeker was, of er nu wel oorlog volgen moest.

Direct na zijn benoeming tot opperbevelhebber trok Hannibal op tegen de Olcaden ${ }^{2}$ ), het volgend jaar tegen de Vaccaeërs, neemt de steden Helmantica en Arbocala, geraakt in grooten nood door een overval der machtige Karpessiërs, maar keert tenslotte toch zegevierend terug naar Nieuw-Karthago (Pol. III r3-I4), waar hij een gezantschap uit Rome aantreft. De gezanten stelden hem twee eischen (III 15, 5):

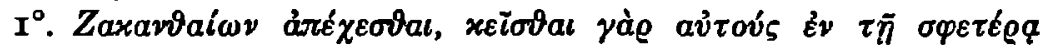
$\pi i \sigma \tau \varepsilon$,

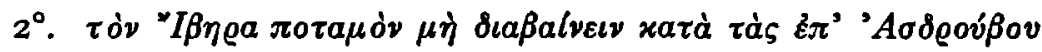

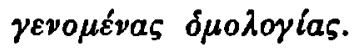

I) III I4, Io.

2) In 221 v. Chr. 
Kort daarvoor (III I4, ro) zegt Polybius, dat Hannibal zijn uiterste best deed om van de Saguntijnen af te blijven: $\tau \alpha \hat{\tau} \tau \eta \varsigma \delta \dot{\varepsilon}$

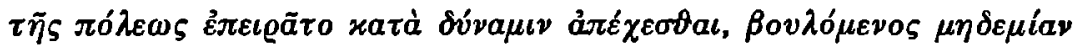

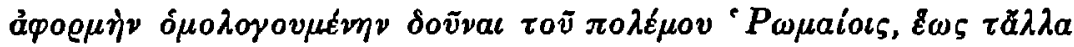

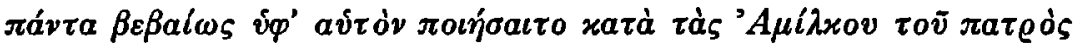

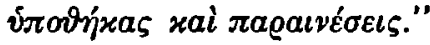

Voor hun eisch inzake Saguntum beroepen de Romeinen zich

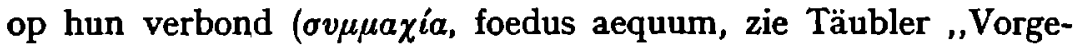
schichte" p. 42-44). Wanneer was dit verbond gesloten?

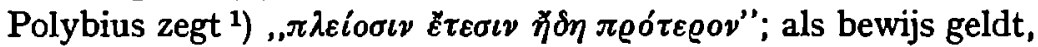
dat de Saguntijnen bij onderlinge twisten niet de Karthagers, maar de Romeinen de bemiddeling opgedragen hadden. Dit bewijst inderdaad, dat er op een gegeven moment een pro-romeinsche meerderheid was, en dat toen de Romeinen ontboden en gekomen zijn; maar over $\pi \lambda \varepsilon i o \sigma \iota v$ z $\tau \varepsilon \sigma \iota v$ zegt het niets. Waarom spreekt Polybius zoo vaag, en noemt hij geen jaartal?

Uit zijn vage woorden hebben De Sanctis ${ }^{2}$ ), Täubler ${ }^{3}$ ), Schnabel 4), Otto ${ }^{5}$ ), Oertel \%), Gelzer ${ }^{7}$ ) als jaar 231 v. Chr. gesteld,

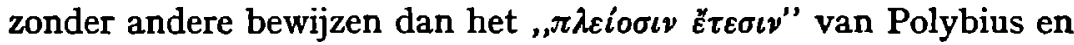
het feit, dat in 23 I het Romeinsche gezantschap zich om Hamilcar toch in Spanje bevond. Kolbe ${ }^{8}$ ) wil het verbond om dezelfde redenen vóór 226 stellen; Meyer ${ }^{\circ}$ ) daarentegen komt op het jaar 223 of 222, zonder positieve argumenten; overtuigender is Groag ${ }^{10}$ ): „Dies (sc. 23I als jaar voor het verbond) wird vor allem dadurch widerlegt, dasz die Römischen Gesandten im Jahre 220 die offizielle

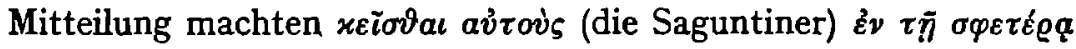
$\pi i \sigma \tau \varepsilon \iota$ (Pol. III 15,5). Da Hannibal mit Sagunt vorher nicht zu tun gehabt hatte, wäre diese feierliche Erklärung ebenso überflüssig wie völlig sinnlos gewesen, wenn schon dem Hasdrubal
I) III 30, I.
2) III 1,417 .
3) Vorgeschichte, p. 43-44.
4) Klio XX, p. I 10.
5) Kriegsschuldfrage, p. 498 .
6) Rh. Mus. 1932, p. 224.
7) Hermes 1933, p. 156.
8) Schuldfrage, p. 18.
9) Sitzungsber., p. 708 .
Io) Hannibal als Politiker, p. $3^{8}$ en p. 53-55. 
dieselbe Mitteilung gemacht worden war" (o.l. p. 38). Hier tegen men aanvoeren, dat de mededeeling over het Ebro-verdrag even onnoodig en zinneloos was, maar toch plaats had.

Een steekhoudender argument is het feit, dat Hasdrubal in 226 de sterkste partij was: volgens Polybius' eigen woorden (II 13, 5-6:

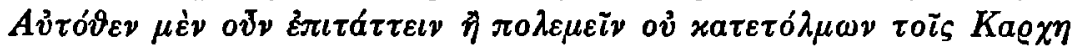

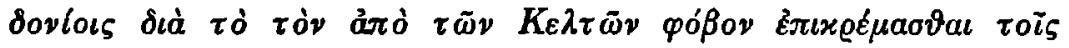

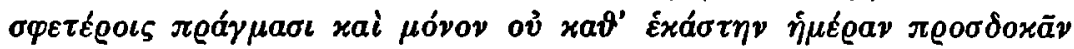

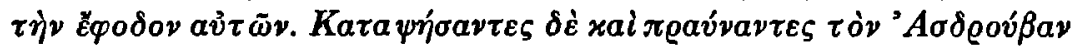

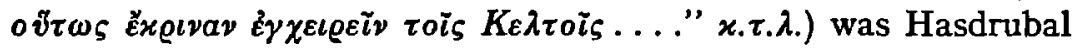
de man, die eischen stellen kon: hij zou een jammerlijke stumper zijn geweest, indien hij bij de afsluiting van het Ebro-verdrag de werking ervan voor zijn eigen voordeel te niet liet doen, door Saguntum aan de Romeinen te laten ${ }^{1}$ ). Kromayer ${ }^{2}$ ), die in zijn betoog Saguntum in bondgenootschap met Rome voor Karthago

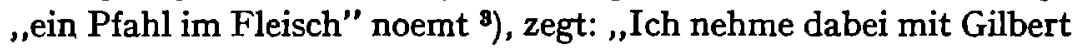
an, dasz erst bei Gelegenheit der scheidsgerichterlichen Intervention Roms in Sagunt nach dem Ebrovertrage die offiziellen Beziehungen zwischen beiden Staaten beginnen, da Polybios in seinem Referat über den Rechtsstandpunkt der Römer $\tau \dot{a}$ í $\dot{o}^{\circ} P \omega \mu a i \omega \nu \lambda \varepsilon \gamma o ́ \mu \varepsilon v a$ (III 29, I) - als einzige wirkliche Thatsache dafür, dasz die Saguntiner in der römischen $\pi l \sigma \tau \iota \varsigma$ gewesen sein, den Umstand anführt, dasz sie Roms Intervention angerufen hätten (III 30,2). Wenn man sich auf weiter nichts stützen konnte - diese Tatsache war überhaupt kein Beweiss für das frühere Vorhandensein eines Bundnisses zwischen Rom und Sagunt - so existierte dasselbe überhaupt nicht" "). Een verder argument liegt m.i. hierin: als het verbond met Saguntum vóór het Ebro-verdrag bestaan had, en de Romeinen hadden het bij de onderhandelingen in 226 niet prijsgegeven ${ }^{5}$ ), dan zou Polybius zich zeer zeker op dit feit beroepen

I) Zoo Schnabel, Klio XX (1926), p. I16.

2) Hist. Zeitschr. I03 (I909).

3) p. $26 r$.

4) p. $257^{2}$.

5) Oertel o.l. p. 224-226 veronderstelt, dat Hamilcar in 226 geen officieel prijsgeven van het sinds $23 \mathrm{r}$ v. Chr. bestaand Rom.-Saguntijnsch verbond kon bewerken: hij zou toen erin toegestemd hebben, dat dit détail voorloopig onafgewerkt bleef: „Der Streit um Sagunt wurde aber vertagt”. Dat Hasdrubal hierdoor alle voordeel voor zich van het verdrag prijsgaf, ziet Oertel 
hebben, waar hij zich nu met het niets-zeggende argument moet behelpen, dat de Saguntijnen een beroep op interventie van Rome en niet van Karthago deden: want dit laatste, het zich kunnen beroepen op Karthago, maar de voorkeur geven aan Rome, veronderstelt een vrijheid naar twee richtingen, die niet vereenigbaar is met een Romeinsch bondgenootschap. Bestond het verdrag echter wel vóór 226, en verviel het door het Ebro-verdrag, dan is het beroep er op door de Romeinen ook onrechtvaardig. Indien het echter na 226 gesloten is - en hiervoor spreken de sterkste argumenten --, is de Romeinsche interventie een volkomen schending van het Ebro-verdrag. Als zoodanig voelde Polybius het aan, en hij voelde de noodzaak om door zijn vage woorden de zaak zooveel mogelijk te verdoezelen ${ }^{1}$ ).

De tweede eisch der Romeinen: de erkenning van het Ebroverdrag door Karthago, krijgt nu een bijzondere beteekenis. Rome deelt mede, dat voor de Romeinen dit verdrag niet meer geldt - zij intervenieeren immers ten Zuiden van den Ebro - maar eischt gelijktijdig, dat Hannibal zich wel aan de bepaling, die Karthago bond, moet houden: wat in 226 gegeven werd als concessie, werd nu als beperking opgelegd.

Wat heeft Hannibal hierop geantwoord?

Volgens Polybius slechts met betrekking tot de Saguntijnen, dat n.l. de Romeinen kort te voren enkele aanzienlijken in Saguntum

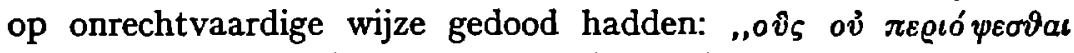

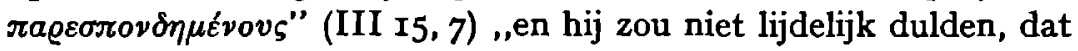
zij het slachtoffer waren geworden van verdragsschending". De Romeinen keeren naar Rome terug met de overtuiging, dat de oorlog onvermijdelijk was, na ook in Karthago dezelfde eischen gesteld te hebben (III I5, I2-I3); Hannibal gaat Saguntum be-

blijkbaar niet in: dat Hasdrubal zelf dit niet ingezien zou hebben, kan ik niet gelooven. De eenige reden, waarom Hasdrubal het verdrag kon sluiten, n.l. de Rom. erkenning van het Karth. imperium ten Zuiden van den Ebro, verviel als hem de volledige souvereiniteit in dat gebied werd onthouden. I) Zie Groag p. 54-56. De clausule over de wederkeerige verplichting voor de Romeinen bij Appianus. Iber. 7 (zie p. 50), kan geen verzinsel zonder meer zijn, daar men den anti-Karthaagschen schrijver, dien Appianus volgt, er niet van kan verdenken anti-Romeinsche bepalingen verzonnen te hebben De eenzijdige bepaling, die Polybius geeft, wordt dan ook terecht algemeen in dezen geest opgevat. 
legeren, de Romeinen bereiden zich op den oorlog voor door eerst even de Illyrische zaken te gaan regelen (III I6, I); maar eerder dan zij verwachtten, wordt Saguntum ingenomen. Als de Romeinen in Illyrië klaar zijn en den val van Saguntum vernemen, zenden zij direct een gezantschap naar Karthago met het ultimatum: Hannibal en zijn mede-schuldigen uitleveren, of oorlog. Dat er in den Romeinschen senaat nog gedebatteerd zou zijn over vrede of oorlog, wordt in heftige polemiek ontkend (III 20, I). De Karthaagsche woordvoerder ontkent de rechtsgeldigheid van het Ebro-verdrag, daar dit slechts met Hasdrubal gesloten was, en niet door den Karthaagschen senaat was bekrachtigd: bij den vrede van 24I hebben de Romeinen zelf de Karthagers dezen rechtsgrond geleerd. En ook op dit Lutatius-verdrag konden de Romeinen zich niet beroepen, want in den lijst der bondgenooten, aan dit verdrag toegevoegd, waren de Saguntijnen niet opgenomen (III 20, 3-4). De Romeinen gaan op de discussie niet in, maar handhaven hun ultimatum, waarop de Karthaagsche spreker handig den Romein den oorlog laat verklaren (III 33, I-4, na een lange discussie over de verdragen, tusschen Rome en Karthago gesloten).

In dit verslag van Polybius zijn enkele duistere en onjuiste punten.

Ten eerste: Hannibal antwoordt de Romeinsche gezanten niets op hun eisch tot erkenning van het Ebro-verdrag; ten tweede: het antwoord van den Karthaagschen senaat op het eerste Romeinsche gezantschap ontbreekt; ten derde: de discussies in den Romeinschen senaat, die, zooals wij pag. 20 zagen, historisch zijn, worden ontkend; ten vierde: de Karthaagsche woordvoerder spreekt zoowel over het Ebro-verdrag als over Saguntum. Hoe is dit alles te verklaren?

Polybius verzweeg, dat Hannibal het Ebro-verdrag verbroken had (zie pag. 4I): daarom missen we ook hier de helft van het antwoord van Hannibal, n.l. dat ook hem het door de tegenstanders geschonden verdrag niet meer bond. Hannibal vraagt in Karthago

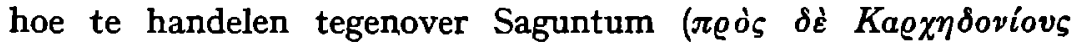

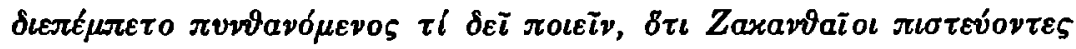

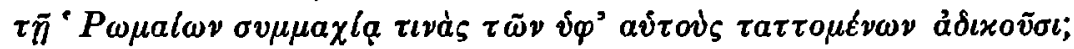
Pol. III I5, 8). Ook hier verzwijgt Polybius het antwoord van den Karthaagschen senaat: dat Hannibal instructies kreeg om op te 
treden tegen Saguntum of minstens om te handelen volgens zijn inzicht (wat in wezen hetzelfde was), blijkt uit Hannibals handelwijze; (wat voor zin had het immers, om instructies te vragen en dan tegen de instructies in te handelen?) en uit het feit, dat de Karthagers later de verantwoordelijkheid voor de daden van Hannibal op zich genomen hebben. Bovendien, de commissie van leden uit den Karthaagschen senaat, die zich steeds bij Hannibal bevond, wordt in 2 I 8 ook door Rome als mede-schuldigen opgeëischt ${ }^{1}$ ): duidelijk bewijs, dat Hannibal verondersteld werd namens den Karthaagschen senaat te handelen, als deze commissie zijn daden goedkeurde ${ }^{2}$ ). In deze zeer gewichtige kwestie blijkt Hannibal zelfs den geheelen senaat van Karthago officieel geraadpleegd te hebben. Hier is dus geen bezwaar het bericht van Appianus te aanvaarden,

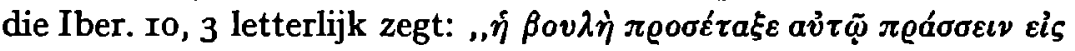

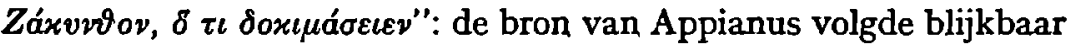
een andere methode dan Polybius: deze verzweeg, gene maakte het tot resultaat van omkooperij en valsche voorlichting.

De discussies in den Romeinschen senaat bewijzen, dat er in Rome een partij was, die tegen den oorlog was; waaruit volgt, dat te Rome de overtuiging heerschte, dat niet Hannibal de man was, die à tout prix den oorlog wilde: dan immers behoefde men er te Rome niet over te debatteeren! Zooals tegenover Hannibal heeft het eerste Romeinsche gezantschap te Karthago den dubbelen eisch gesteld: de erkenning van het Ebro-verdrag en de onschendbaarheid van Saguntum. Het door Polybius verzwegen antwoord kan men opmaken uit de daden van den Karthaagschen senaat: beide eischen moeten afgewezen zijn: want Hannibal krijgt de vrije hand tegenover Saguntum; en bij het tweede gezantschap verwerpen zij het Ebro-verdrag als niet-bindend, en juist het verloop der zitting te Karthago bij het tweede gezantschap maakt duidelijk, wat er bij het eerste gezantschap besproken is: bij het tweede gezantschap bestrijden de Karthagers nog de beide postulaten uit de eerste zitting, die de Romeinen nu niet noemden, daar er een geheel andere toestand was ontstaan door den val van Saguntum; nu stelden de

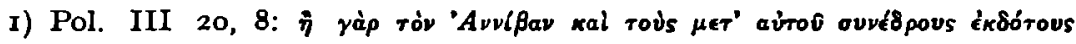
8.Sdvat 'Pwpaiots..."

2) Men zie Pol. VII 9: , 'Opros ôv ë

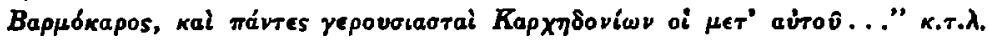


Romeinen slechts het ultimatum: uitleveren, of oorlog! Hadden de Karthaagsche senatoren bovendien bij het eerste gezantschap niets geantwoord, of, in den trant zooals Gelzer ${ }^{1}$ ) en Kolbe ${ }^{2}$ ) het zich indenken, het antwoord gegeven, dat zij geenszins met de daden van Hannibal accoord gingen, dan had Polybius, die zooveel moeite heeft met het bewijs der Karthaagsche schuld, het zich heel wat gemakkelijker gemaakt, en het antwoord van den Karthaagschen senaat niet behoeven te verzwijgen. Wat het feit betreft, dat de Karthaagsche senatoren expressis verbis het Ebro-verdrag als nietbindend verwierpen, is het onmogelijk dat dan Hannibal een ander standpunt heeft ingenomen: in alles immers moest de Karthaagsche senaat, niet van de situatie in Spanje op de hoogte, zich door Hannibal en de bij hem aanwezige gerousiasten laten voorlichten. Het is ondenkbaar, dat zij in deze kwestie een andere gedragslijn volgden, dan hun vanuit Spanje was geadviseerd.

Samenvattend constateeren we dus in de aanleiding tot den tweeden Punischen oorlog:

Rome schendt het Ebro-verdrag door de interventie in Saguntum en eischt van Karthago de goedkeuring van deze verdragsschending. (Hannibal en Karthago worden officieel van deze schending op de hoogte gesteld: een berusten zou dus officieel goedkeuren zijn geweest).

Hannibal en de Karthagers verklaren nu ook hunnerzijds het Ebro-verdrag voor ongeldig en wijzen den eisch van Rome op de meest energieke wijze af: Saguntum wordt met geweld veroverd.

Rome stelt nu een ultimatum: alsnog de gestelde eischen inwilligen; hetgeen nu nog slechts kon geschieden door schadevergoeding te geven aan de Saguntijnen en Hannibal uit te leveren.

Karthago weigert, en Rome verklaart den oorlog.

1) Gelzer, 0.1. p. I 58 .

2) Kolbe o.l. p. 19. Kolbe argumenteert verder alsof het antwoord van de eerste senaatszitting volkomen bekend was, en - hoewel uitsluitend tegen de Karthagers te gebruikenl - toch door Polybius verzwegen is. 


\section{KARTHAGO VAN 241 TOT 218 v. CHR.}

Zooals we zagen ${ }^{1}$ ), gaf Polybius als oorzaken van den tweeden Punischen oorlog: de wrok van den ongeslagen Hamilcar, de verbittering bij de Karthagers over den roof van Sardinië en de macht, in Spanje verworven. Als bewijs hiervoor gaf hij „ofschoon men veel meer zou kunnen vinden" 2) slechts den eed, dien Hamilcar zijn negenjarig zoontje Hannibal deed afleggen ,jegens de Romeinen nooit welgezind te zullen zijn". Het gevolg is, dat Hannibal direct na den dood van Hasdrubal op maatregelen zint om de Romeinen te beoorlogen - en dat deze dit doorzien en op tegenweer

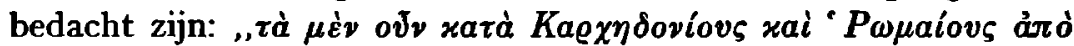

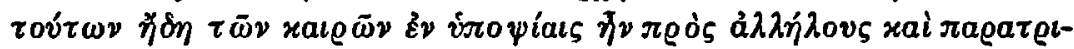

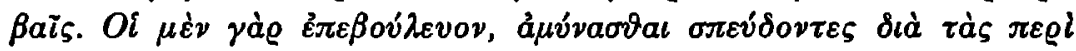

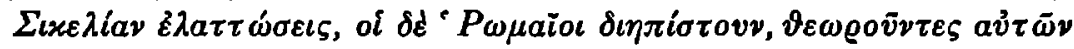

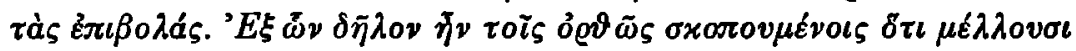

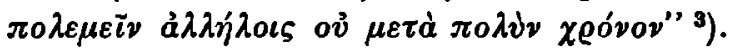

In deze woorden van Polybius spelen zijn apriorismen hem weer leelijk parten. Immers, waarin deze wrijvingen bestaan hebben, zegt Polybius nergens; aanslagen van de Karthagers op de Romeinen in deze periode vermeldt hij zelfs niet bij de felle discussies over de oorzaken van den oorlog; hij weerspreekt deze woorden zelf in III I4, Io, als hij beweert, dat Hannibal den Romeinen geen enkel motief tot oorlog wilde geven, vóórdat hij geheel de rest van

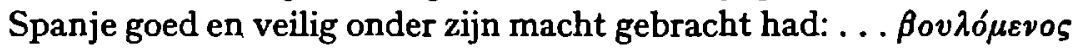

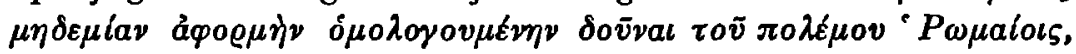

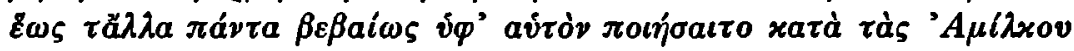

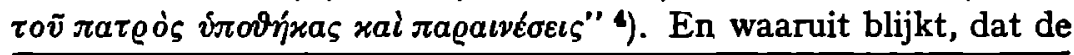

I) Pag. 30-32.

2) III 10, 7 .

3) II $36,4-7$.

4) III I4, Io. 
Romeinen zeker revanche van Karthago duchtten? Indien de Romeinen in 22I reeds overtuigd waren van de noodzakelijkheid van den oorlog, dan is hun gedrag tegenover Saguntum erger dan onverklaarbaar: want voor toen kon zelfs het excuus van 2r9, de illyrische oorlog, nog niet gelden. Waarom de bondgenooten niet tijdig beschermd? Integendeel, indien de Romeinsche senaat in 219 tijdens het beleg van Saguntum overtuigd was van de noodzakelijkheid van den oorlog, en van zijn goed recht op bondgenootschap met de belegerde vesting, staat het niet-helpen gelijk met snood verraad. Maar zelfs na den val van Saguntum is er in den Romeinschen senaat nog gedelibereerd over vrede of oorlog: zoo weinig stond de toekomstige oorlog vast.

Rest als eenig bewijs voor de stelling van Polybius het verhaal van Hannibals eed van eeuwigen haat. Boven ${ }^{1}$ ) zagen we reeds, hoe bedenkelijk de historische waarde van dit verhaal is: maar zelfs indien we de absolute zekerheid hadden voor de historiciteit, bewijst de eed nog slechts, dat Hamilcar verbitterd was, dat hij zijn haat naar best vermogen in zijn zonen heeft ingeprent, dat die haat dus de oorzaak had kunnen worden, — niet, dat hij ook werkelijk de oorzaak geworden is.

We gaan de daden na der Karthagers gedurende de periode na den vrede van $24 \mathrm{I}$ tot het begin van den oorlog in $2 \mathrm{I} 8$, om daaruit hun bedoelingen te vernemen.

$\mathrm{Na}$ den vrede van Lutatius werd Karthago met den algeheelen ondergang bedreigd door den opstand der huurlingen: slechts met inspanning van alle krachten en na jaren strijden (24I-238) wordt onder leiding van Hamilcar het oproer bedwongen. Ook de troepen op Sardinië, welk eiland nog aan Karthago toebehoorde, gingen tot opstand over; dit leidde voor Karthago tot verlies van dit eiland, dat door de Romeinen in bezit werd genomen. Hoe ging dit in zijn werk?

In de mededeelingen hierover kunnen we twee groepen onderscheiden:

I. Polybius. I 79. 88, 8-I2. III 15, I0. $27-28$.

In I 79 en 88 , 8-12 vertelt Polybius: tijdens den Afrikaanschen opstand komen ook de huurtroepen op Sardinië in verzet: zij dooden de aanwezige Karthagers. Vanuit Karthago wordt Hanno met een

I) Pag. 24-26. 
leger gezonden om de oproerlingen te onderwerpen: maar ook dit leger loopt naar de tegenstanders over, Hanno wordt gekruisigd. Later worden de huurlingen door de inwoners van Sardinië verdreven: ze vluchten naar Italië en bieden hun eiland den Romeinen aan: deze aanvaarden het, doch eerst nadat de opstand in Afrika beëindigd is. De Karthagers zijn verontwaardigd: zij waren bezig een expeditie uit te rusten om het eiland te heroveren. Rome verklaart Karthago den oorlog, onder het motief, dat de Karthaagsche voorbereiding niet Sardinië betrof, maar de Romeinen zelf. Karthago is echter absoluut niet in staat nu oorlog te voeren: de vrede wordt gekocht voor I200 talenten en den afstand van Sardinië. In boek III I5, 1o wordt de handelwijze der Romeinen onrechtvaardig genoemd, III 28 eveneens: hier wordt weerlegd de bewering der Romeinen, die den roof van Sardinië rechtvaardig

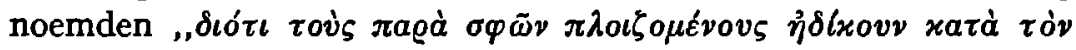
$\Lambda \iota \beta v x o ̀ v \pi o ́ \lambda \varepsilon \mu o v "$ ": dit geschil was immers bijgelegd door de uitlevering der gevangen kooplui door de Karthagers, waarop de Romeinen op hun beurt de Karthaagsche krijgsgevangenen, die zich nog in hun macht bevonden, aan Karthago teruggegeven hadden.

2. Livius, Appianus, Cassius Dio.

Het uitvoerige bericht van Livius is met de tweede decade verloren gegaan; zijn woorden in XXI I, 5 (Sardiniam inter motum Africae fraude Romanorum stipendio etiam imposito interceptam) bewijzen, dat de woorden van Orosius IV II (, . . . ut Sicilia Sardiniaque decederent") slechts een onnauwkeurigheid inhouden, veroorzaakt door al te gedrongen weergave. Appianus bericht Libyc.

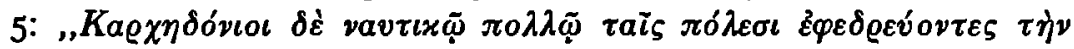

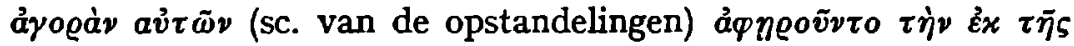

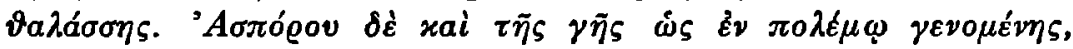

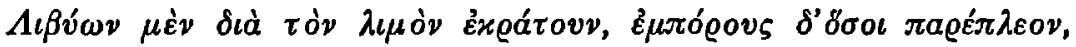

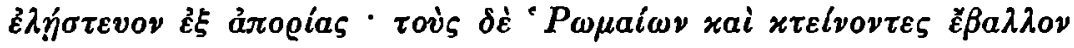

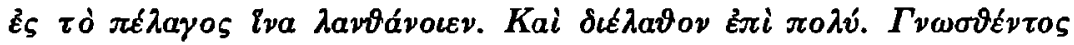

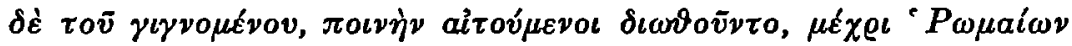

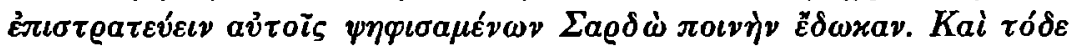

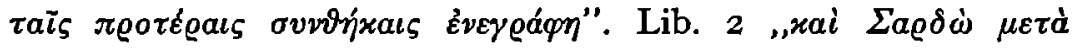

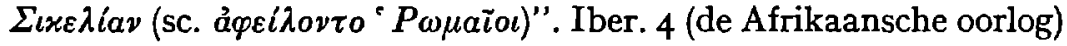

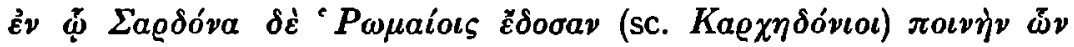

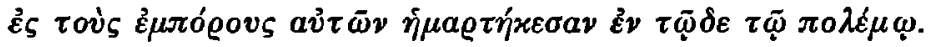




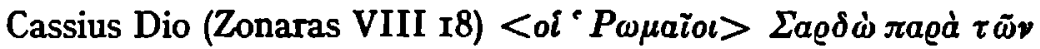

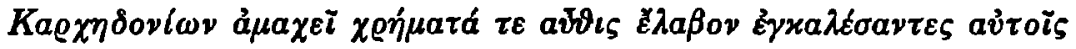

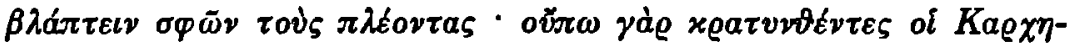

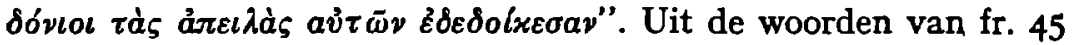

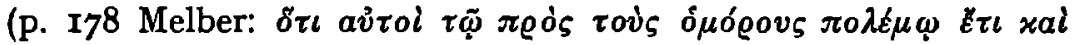

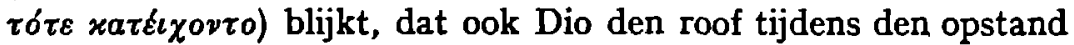
stelt.

Polybius kende dus een lezing, welke den roof van Sardinië in verband bracht met een conflict tusschen Rome en Karthago over Romeinsche koopvaarders. Dit conflict was, naar uit het verhaal van Polybius en Appianus blijkt, als volgt ontstaan: de Karthagers blokkeeren den toevoer van levensmiddelen naar de opstandelingen: daarbij nemen zij Romeinen gevangen, die ondanks de vriendschap, in 24I tusschen de beide staten gesloten, aan de opstandelingen levensmiddelen leverden ${ }^{\mathbf{1}}$ ). Bij de onderhandelingen, die over deze kwestie gevoerd worden, erkennen de Romeinen blijkbaar het ongelijk hunner kooplui, want als de Karthagers die vrijlaten, geven de Romeinen de Karthaagsche krijgsgevangenen, die zij nog hebben, gratis terug en staan Karthago zelfs toe in Italië troepen te werven. Polybius wijst op de onmogelijkheid, dat dit conflict met den roof van Sardinië in verband gebracht kan worden: het was vóór den roof reeds lang bijgelegd. Er is geen motief te vinden, waarom Polybius deze feiten zou hebben vervalscht; blijkbaar hebben de Romeinsche schrijvers, als excuus voor den roof, dezen in verband gebracht met z.g. onrecht der Karthagers jegens hun kooplui. Polybius toont dan zeer eenvoudig de onmogelijkheid hunner argumenteering aan, en klaarblijkelijk hebben de Romeinsche annalisten, wier producten we bij Appianus en Dio voor ons hebben, het argument van Polybius ,weerlegd" door den ,,afstand" van Sardinië rustig tijdens den Afrikaanschen oorlog te plaatsen. Bovendien, een element dat we niet mogen wegcijferen uit de overlevering, wijst duidelijk op het beëindigd zijn van den opstand: de Romeinsche oorlogsverklaring volgde naar aanleiding van Karthaagsche maatregelen tot herovering van Sardinië. Maar Karthago kan niet voor de tweede maal een leger hebben uitgezonden, zoo-

I) Dit wordt in de lezing van Appianus ,zeeroof door de Karthagers uit gebrek". 
lang het zelf nog door den opstand bedreigd werd, en de eerste expeditie zoo jammerlijk mislukt was ${ }^{1}$ ).

Waarom heeft Rome in 237 Sardinië geroofd, en het niet in $24 \mathrm{I}$ geëischt?

Reeds Mommsen nam aan, dat Rome in 24I, ook zelf sterk verzwakt, den vrede wilde en daarom de eischen niet overdreef. Täubler ${ }^{2}$ ) verwerpt dit en wijst op de toenmalige overmacht van Rome; de "geopolitische Idee" dat Sardinië noodig was om van Italië een afgerond geheel en van de Tyrrheensche Zee een Romeinsche Zee te maken, zou in $24 \mathrm{I}$ nog niet bestaan hebben, maar pas in 238 gerijpt zijn. Maar hij vergeet te vermelden, dat reeds Regulus in 256 de afstand geëischt had! In 24I had Lutatius de praeliminairen opgesteld, de comitia hebben de voorwaarden verscherpt, en gingen daarbij wel tot het uiterste van wat ze meenden te kunnen bedingen. De algeheele uitputting van Karthago na den Afrikaanschen oorlog werd wel de aanleiding om het reeds lang begeerde Sardinië in te lijven.

De verbittering over dit onrecht nu zou de hat van Hamilcar nog versterkt hebben, en zijn landgenooten voor de idee van revanche gewonnen hebben. Daar er voor de vernietiging van Rome naar nieuwe middelen gezocht moest worden, ging Hamilcar naar Spanje: daar was geld, daar waren soldaten.

1) De Sanctis (Storia di Roma III r, p. 400-40r) probeert nog een soort excuus: de bijgelegde incidenten moeten zich herhaald hebben (, Ma, certo, il rinnovarsi di contrasti come i già sopiti era inevitabile") en zoo aan de Romeinen gelegenheid hebben geboden opnieuw aangeboden satisfactie van de Karthagers niet te aanvaarden. Daargelaten, dat er voor die herhaling geen spoor van overlevering of bewijs is: hoe is deze lezing te vereenigen met het feit, dat de oorlog verklaard werd om de z.g. Karthaagsche mobilisatie tegen Rome? Gelzer (Hermes 68, 1933) heeft weer de z.g. Fabiaansche verdediging voor den roof: hij wijst op de gevangenneming der Romeinsche koopvaarders en de mobilisatie der Karthaagsche oorlogsvloot in 238: „Da bleibt für Rom nichts anderes übrig, als durch Präventivkrieg rechtzeitig abzuwehren". W. Kolbe (,Die Kriegsschuldfrage", p. 30-32) heeft de theoriēn van Gelzer, die nota bene gebaseerd zijn op de dwaasheden van Laqueur over Polybius, afdoende weerlegd: op een eenvoudige dreiging van Rome moet Karthago den vrede koopen voor 1200 talenten en den afstand van Sardinię: en datzelfde Karthago zou tegelijkertijd Rome de noodzaak van een "Prāventivkrieg" opgedrongen hebben!

2) „Die Vorgeschichte", p. 2 I. 
Deze zienswijze van Polybius is niet de oudste ${ }^{1}$ ). Fabius Pictor zag, zooals we constateerden, de oorzaak van den oorlog in de hebzucht en de heerschzucht van Hasdrubal: dit nu sluit de verbittering van Hamilcar als oorzaak van den oorlog niet alleen uit, maar ook als motief voor de stichting van het imperium in Spanje. Tegenover de bewering, dat na 237 ook de Karthagers op revanche zonnen, staat de bewering van Fabius, dat de politiek van Hasdrubal en Hannibal positief tegen den wil van alle aanzienlijke Karthagers inging. $\mathrm{Nu}$ mogen de beweringen van Fabius omtrent den tegenstand der Karthagers sterk overdreven zijn, een feit blijft, dat Fabius als senator en tijdgenoot zich van de inzichten zijner tijdgenooten en van de feiten op de hoogte heeft gesteld ${ }^{2}$ ); redenen om Hamilcar anders te beoordeelen dan Hasdrubal waren er geen. Het inzicht van Polybius is dus ook in deze kwestie een apriorisme, voortvloeiend uit zijn algemeene opvatting over Hamilcars schuld aan den oorlog, en zonder nader bewijs niet aanvaardbaar.

Voor de jaren 235 tot 233 v. Chr. geeft Cassius Dio (Zon. VIII, 18) herhalingen van de gebeurtenissen om Sardinië zooals in 238 , met geringe variaties; naar uit Orosius IV I2, 2 blijkt, deed ook Livius dit voor 235 . In 230 zouden de Karthagers zich zelfs hebben voorbereid om tegen Rome op te trekken, daar de consuls M. Aemilius en $M$. Junius toch hun handen vol hadden tegen - de Liguriërs! Täubler ${ }^{3}$ ) heeft deze doubletten duidelijk als falsificaties der annalisten gebrandmerkt; als bron dezer fantasien wijst hij Cato aan (waarin zelfs Groag hem volgt); bij Ennius zouden ze reeds gestaan hebben 4 ). Norden heeft deze gegevens benut voor zijn reconstructies van de Ennius-fragmenten: we zagen ${ }^{5}$ ), dat om eenvoudige chronologische feiten deze volgorde onmogelijk is. Het onmisbare element in de geheele geschiedenis is: de wrok der Karthagers en der Barkiden om Sardinië, en dit eischt de visie van Polybius.

Nu staat bij Varro, De lingua Latina V I65: ,tertia est (sc. porta)

I) Men zie hiervoor Groag: „Hannibal als Politiker”, p. 2 I-22.

2) Groag, P. 21 .

3) „Die Vorgeschichte”, p. 36-37. Men controleere bij Pais, Storia di Roma I 156 de opgave der bronnen! Zelfs de Sanctis III I, 28I-282 verwerpt de doubletten als onhistorisch.

4) „Die Vorgeschichte”, p. 40.

5) E. Norden: „Ennius und Vergilius". 
Janualis, dicta a Jano, et ideo ibi positum Jani signum et ius institutum a Pompilio, ut scribit in annalibus Piso, ut sit aperta semper, nisi cum bellum sit nusquam. Traditum est memoriae Pompilio rege fuisse opertam et post T. Manlio consule bello Cartaginiense primo confecto et eodem anno apertum". Het vermoeden ligt voor de hand, als uitvinder van de falsificaties aan L. Calpurnius Piso Frugi te denken, die na Polybius schreef; fr. 3I (uit Plinius N.H. 15, 126; Peter Hist. Rom. Rell. I, p. 135) handelt over Papirius Maso, die over de Corsikanen getriompheerd heeft. Dit vermoeden wordt nog versterkt door de ,,antiquarisch-mythologische Gelehrsamkeit, die sich in manchem Bruchstück zeigt" '), en die ook uit deze geheele passage sterk spreekt.

In volkomen tegenspraak tot de berichten over de Karth. intriges op Sardinië staat het bericht van Cassius Dio (fr. 46, Melber p. 180)

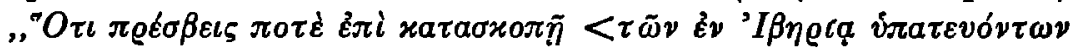

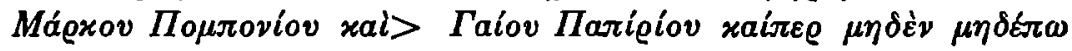

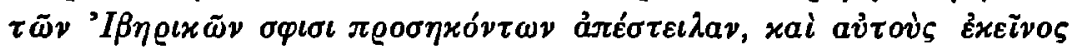

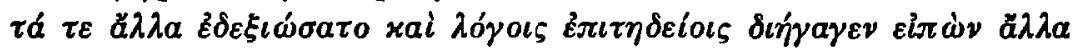

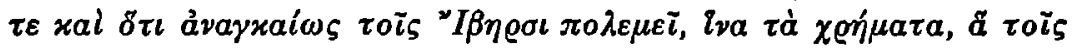

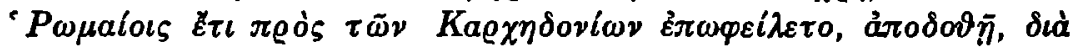

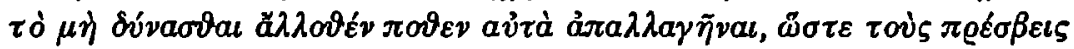

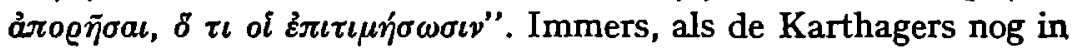
zulk een toestand van afhankelijkheid zijn als uit deze scène spreekt, is het niet mogelijk, dat zij een houding aannemen als door Dio (zie p. 54) beschreven.

Toch is dit merkwaardige bericht door zoo goed als niemand bestreden, en terecht: als verzinsel van een annalist kan men het niet bestempelen, daar er geen enkele pro-Romeinsche tendenz uit spreekt $\left.{ }^{2}\right)$.

I) Schanz-Hosius: „Geschichte der Röm. Litteratur"‘, p. I95.

2) Men zie Meltzer: „Geschichte der Karthager” II p. 402-403; Taubler: „Die Vorgeschichte”, p. 68. De Sanctis (III I, p. 4I I) laat de Romeinen gaan controleeren, of er geen gevaar bestond, dat de Karthagers vanuit Spanje de hand zouden reiken aan de Galliërs in Noord Italie,, die zich voorbereidden tot den oorlog tegen Rome en daarvoor aan gene zijde van de Alpen hulp zochten. Maar dertien jaar later, toen de verovering van Spanje veel verder gevorderd was, bleek Hannibals tocht nog een verrassing voor de Romeinen! Slechts J. S. Reid (.,Problems of the second Punic war", in Journ. of Roman Studies III r913, p. 175-196), sprekend over de passage van Pol. II 13, 
Kan er dus geen enkel feit aangetoond worden, waaruit de opzet en voorbereiding tot revanche voor Hamilcar blijkt, evenmin is dit mogelijk voor Hasdrubal, die in 229 na den dood van Hamilcar het opperbevel kreeg (en wel legaal: Pol. II I, 9: „Tìv $\delta \dot{\varepsilon} \sigma \tau \varrho a \tau \eta \gamma i a \nu$

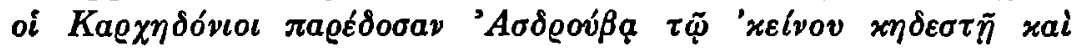

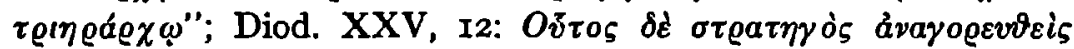

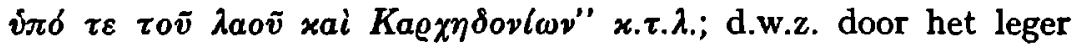
gekozen, bevestigd door de bevoegde instanties te Karthago). Naar we pag. 76 zagen, stelde Fabius Pictor slechts de hebzucht en heerschzucht van Hasdrubal als oorzaak van den oorlog. Het bewijs van Fabius kan moeilijk iets anders zijn geweest, dan de mededeeling, dat hij zijn gegevens van de aristocraten uit Karthago zelf had: de polemiek van Polybius: „waarom hebben die Karthagers in 218 Hannibal dan niet uitgeleverd" sluit het bestaan van andere motiveeringen uit. Dat zulke taal in Karthago na het verlies van den oorlog inderdaad gevoerd is, is alleszins aannemelijk: juist de anti-Barkinische partij moet zoo gesproken hebben ad captandam Romanorum benevolentiam: deze hadden zij noodig als tegenwicht tegen de populariteit, die de Barciden ook toen nog genoten, zooals blijkt uit het feit, dat Hannibal in r 96 tot suffeet gekozen, een reorganisatie in het staatsbestuur kon doorvoeren (Livius XXXIII, 46 en 47) ${ }^{1}$ ). Maar tegenover zulke taal staat een daad van Hasdrubal: toen de Kelten van Noord-Italië, versterkt met 70 ooo Gaesaten uit Gallia Trans-Alpina, den oorlog gingen ondernemen om Rome te verwoesten, heeft Hasdrubal deze gelegenheid niet benut om de z.g. revanche-idee te verwezenlijken, maar met de Romeinen het Ebro-verdrag gesloten ${ }^{2}$ ): de diplomaat maakte

waarin deze verklaart, dat de Romeinen de zaken in Spanje verwaarloosd hadden, gaat voort: ,This renders highly improbable the statement of Dio Cassius, that a commission was sent from Rome in 231 to inquire into the situation in the peninsula". Hiertegen zij opgemerkt, dat vijf jaar lang is, als het gaat over een land, dat met overmacht door een andere mogendheid wordt veroverd; dat men geen reden kan zien, waarom de bron van Dio dit gezantschap zou hebben verzonnen; en dat juist de woorden van Pol. II r 3. 4, een gewoonte van controle en tegenwerking bij de Romeinen verraden, die het gezantschap van 231 volkomen verklaren.

I) Zie p. 27

2) De tijd, \pm 226, blijkt uit Pol. II 13, 7: als het Ebroverdrag gesloten is, beginnen de Romeinen direct den oorlog tegen de Kelten: .,eviows Éf fucyray

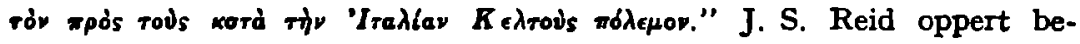


van de situatie gebruik om, ongehinderd door de Romeinen, zijn doel te kunnen bereiken. Maar dan kan dit doel slechts geweest zijn: de stichting van een rijk en onontbeerlijk imperium voor Karthago; de vaste wil tot oorlog ware met deze handelwijze volkomen onvereenigbaar. Men moge zeggen, dat de Semitische koopmansgeest een mooie gelegenheid liet voorbijgaan om een klein gewin (,Der Ebrovertrag ist ein voller diplomatischer Erfolg Roms in einer gefährlichen Situation .... Dagegen tauschte Hasdrubal nur den Vorteil ein, ungehindert durch Römische Intervention das Land bis zum Ebro seinem Machtsbereich einverleiben zu können", Schnabel, Klio XX, p. II6): de Semitische koopman wist toch in elk geval wel, wat hij wilde: en dat was geen oorlog met Rome. Dat ook Hannibal geen enkele daad stelde, waardoor hij zijn oorlogswil toonde, hebben we in Hoofdstuk II betoogd; zijn tochten naar het binnenland van Spanje kan men bezwaarlijk met gezond verstand zoo uitleggen ${ }^{1}$ ), en in het conflict om Saguntum ging het initiatief van Rome uit.

zwaren (0.1. p. I77): „At the time, Hasdrubal had been barely three years in command, and his course had still five years to run (deze opmerking is bepaald geestig!). The greater part of his work must have been still to do. It is not likely that he had carried his influence to any point near the banks of the Ebro. Polybius, like all other ancient authorities, felt surprise at the supineness of the Romans in face of Hasdrubal, and he, with others, may thus have been led to assign too early a date to the agreement. If the negotiacions accured near the time of Hasdrubal's death, they would be more intellegible. Assuming that the understanding was really reached in 226, we must suppose that the Romans recognised for Carthage a large liberty, that of extending, without offence, ber dominance over a very wide territory in which she had not as yet acquired influenced". Juist indien Hasdrubal zijn invloed wel uitgestrekt had tot aan den Ebro, ware het verdrag onbegrijpelijk, daar Rome om het Keltengevaar aan Hasdrubal een flinke concessie moest doen. Het Ebroverdrag is niet los te maken van het Keltengevaar: daarmee blijft de tijd aangegeven.

I) Men zie o.a. Kromayer, Hist. Zeitschr. ro3, p. 252 en Groag, „Hannibal als Politiker", p. 50-5I. 


\section{HOOF DSTUK I V}

\section{DE POLITIEK VAN KARTHAGO EN VAN ROME.}

Polybius heeft zijn idee, dat de oorzaak van den tweeden Punischen oorlog bij de Karthagers lag, a priori opgesteld, uitgaande van de overtuiging, dat de idee van directe, rechtstreeksche vergelding in de politiek even goed werkt als in de individueele verhoudingen; psychologisch heeft hij haar gesteund door het verhaal van den eed van haat jegens Rome, dien de wrokkende Hamilcar den nog kinderlijken Hannibal liet zweren; factisch heeft hij haar willen bevestigen door bij de aanleiding tot den oorlog de schuld aan de Karthagers, en speciaal aan den oorlogszuchtigen, onbesuisden Hannibal toe te schrijven. De laatste beschuldiging heeft tegenover de feiten geen stand gehouden; indien men het verhaal van den eed ook al volkomen aanvaardt, dan erkent men daarmee hoogstens de historiciteit van den haat, waaruit de oorlog had kunnen ontstaan - meer niet: want daden, die men zonder apriorismen aan oorlogswil moet toeschrijven, heeft geen der Barciden gesteld. En zoo rest nog slechts de overtuiging, dat de zucht tot revanche ook in de politiek een psychologische noodzaak is.

Hoe algemeen menschelijk de wraakgedachte nu ook zijn moge, bewijzen toch recente gebeurtenissen in de samenleving der volkeren, dat naties jaren lang in fellen haat jegens elkander kunnen voortleven, dat die haat tot oorlog of oorlogsdreiging en tot bezetting van gebied kan leiden, dat de zwakste partij overweldigd kan worden - om direct daarop te verklaren, dat men tot vriendschap en cordiale samenwerking bereid is. In het leven der staten domineert de ratio; het menschelijk sentiment is voor den politicus

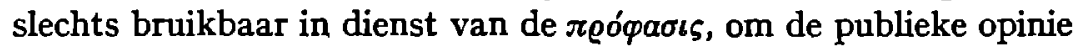
in de gewilde richting te leiden.

Het onderzoek in de vorige hoofdstukken bleef beperkt toteen korte periode. Het resultaat was, dat bij Karthago en zijn veldheeren geen 
positieven wil tot oorlog, die zich in daden uitte, aan te wijzen viel.

Gaan wij nu zien, of in de algemeene politiek van Karthago vóór 238 factoren aanwezig zijn, die erop wijzen, dat de revancheidee een noodzakelijke consequentie is van den Karthaagschen volksaard en van het karakter van zijn politiek ${ }^{1}$ ).

„Urbs antiqua fuit, Tyrii tenuere coloni": zoo begint Vergilius Aeneis I I2 na het prooemium zijn eigenlijk verhaal. Kolonisten uit Tyrus waren de Karthagers: Phoenicisch is dus hun volksaard. Dat de Phoeniciërs \pm Iooo v. Chr. handel dreven in de landen aan de Aegaeische Zee, is bekend: zij waren de bemiddelaars, die aan de Grieken de cultuurgoederen brachten uit het Oosten, zooals blijkt uit de overname van het Phoenicische schrift door de Grieken; zij waren ook de sluwe kooplui, wier reputatie reeds vroeg van dien aard was, dat Homerus (Od. 15, 4I5) Odysseus liet spreken over „Phoeniciërs, beroemd om hun scheepvaart, sjacheraars, met ontelbare snuisterijen in hun zwart-geteerde schip" - en dat in een gesprek tot Eumaeus, dien Odysseus misleidde, tegen wien hij dus geloofwaardige taal moest spreken. Een dergelijk beeld geeft ons Herodotus (I I), terwijl ook hij een scène geeft uit het grijze verleden.

Door de zee-minnende Grieken zijn de Phoeniciërs uit de Grieksche zeeën verdreven; van gewapende conflicten vernemen we niets: de zee was nog groot genoeg, en de Phoenicische kolonies ontstonden op alle kusten van de landen aan de Middellandsche Zee. Zooals de Phoeniciërs hun steden bouwden: kustplaatsen, met geen interesse voor den bodem, geen uitplanting van de bevolking over de streek, zoo stichtten zij ook hun kolonies. De eerste eisch was, dat er handel gedreven kon worden. Ondanks hun primitieve schepen ondernamen zij verre reizen, en hun ingeboren koopmansaard deed hen overal de juiste standpunten kiezen: vele Phoenicische factorijen zijn uitgegroeid tot machtige steden, die grootendeels nooit meer opgehouden hebben te bestaan, maar die - en dit is veelzeggend - bijna nooit Phoenicische steden werden. Want zooals in het Oosten hebben ook in het Westen de Grieken de semitische voortrekkers op vele plaatsen verdreven, en van de handelsplaatsen vepsterkte steden gemaakt, die zij verder bewoonden en

I) Zie Meltzer: , ,Geschichte der Karthager”' I en II. J. Kromayer: ,, Hannibal als Staatsmann", Hist. Zeitschr. 103 (I909), p. 24I ssqq.; Ehrenberg: „,Karthago". 
zoo noodig hardnekkig verdedigden als gold het hun oorspronkelijk vaderland, terwijl de semiet rustig elders zijn handel ging zoeken. Geen pogingen om gebied van andere staten te onderwerpen, geen stichting van imperia, ver of dichtbij: handel, maar die dan ook overal en met iedereen.

Grieken en Romeinen ver o verde n den grond, waarop zij hun steden stichtten: met minachting laat Vergilius koning Iarbas over de stichters van Carthago zeggen:

„femina, quae nostris errans in finibus urbem „exiguam preti o posuit -" (Aen. IV 2II).

Slechts indien zij moesten vechten voor eigen behoud, hebben zij gestreden, maar dan ook met ongeloofelijke hardnekkigheid, met echt oostersch fanatisme: de groote Alexander had zeven maanden noodig voor de verovering van Tyrus.

De groote afstand tusschen het vaderland en de factorijen in het westelijk deel van het Middellandsche Zeegebied moest leiden tot de stichting van een nieuw centrum: handelsbelangen waren het, die hier een nieuwe stad deden ontstaan: Karthago. Door de ideale ligging kwam de stad spoedig tot grooten bloei: de dreigende overheersching der Grieken, die in Italië, op Sicilië, zelfs op Sardinië, in Gallië en Spanje succesvol de Phoenicische factorijen verdreven, probeerde men tegen te houden door bondgenootschappen met andere, evenzeer bedreigde staten: de Etruskers aanvankelijk, en, toen door de zelfstandigheid en de ontwikkeling van Rome, de Etrurische macht ging tanen, met de Romeinen. De inhoud der afspraken ${ }^{1}$, waarin Karthago zijn belangen veilig stelde, toont duidelijk den koopmansaard der contrahenten: nauwkeurig wordt voor elk der partijen zijn terrein afgebakend, waar hij geen concurrentie in handel en zeerooverij zal hoeven te duchten.

Door de nabije ligging van Sicilië was voor een onbedreigde verbinding met de factorijen het permanent bezit van den westpunt absoluut noodzakelijk: de vesting en havenstad Lilybaeum en het omliggend gebied hebben de Karthagers daarvoor gesticht en steeds met succes tegen de Grieken verdedigd. Tot ditzelfde doel diende ook het laatste verdrag, dat vór den eersten Punischen oorlog met Rome gesloten werd, en dat Pyrrhus moest beletten geheel Sicilië tot een zuiver-Grieksche macht te maken.

I) Pol. III, 22-25. 
Het échec van Pyrrhus op Sicilië, zijn vertrek naar Italië en daarop naar Griekenland scheen aan alle gevaar een einde te maken: de Grieken op Sicilië, onderling verdeeld als altijd, vormden geen bedreiging; naar Italië koesterde men geen aspiraties, met Rome leefde men sinds eeuwen in vriendschap; op de kusten van Afrika, Zuid-Spanje, Sardinië en Corsica had men factorijen of bevriende steden; door Massilia strekte de handel zich uit tot in Zuid-Gallië. Geld was er in overvloed, en daarmee veiligheid: want, al was de Karthaagsche koopman geen soldaat - zooals zelden een goed soldaat tevens goed koopman is - voor geld kon men zooveel soldaten huren als voor de veiligheid van den handel noodig was. De Karthaagsche schepen voeren naar alle streken, een voortreffelijke oorlogsvloot beschutte voor zeeroovers. Ter zee was men onbestreden heerscher; land bezat men weinig, begeerde men nog minder; de $\vartheta a \lambda a \sigma \sigma o x \varrho a \tau i a$ diende om de handels- en afzetgebieden te handhaven, er nieuwe bij te winnen, niet tot verwerving van territoriaal bezit.

Als de regeering van een volk streeft naar macht en uitbreiding, is de ultima ratio: scheppen en handhaven der bestaansmogelijkheden van de burgers. Nu kan men de macht baseeren op het bezit van den grond: de regeering zal dan met wapengeweld zich van het land van vreemde volkeren meester maken, en dan die volkeren behandelen naar gelang men meent, dat de belangen van den eigen staat en eigen burgerij er het best door gediend worden. Deze methode pasten, onder zeer vele anderen, ook de Romeinen toe. Men kan de macht echter ook baseeren op het bezit van geld, waarbij men zich om het souverein bezit van den bodem niet bekommert: het Karthaagsche volk is niet het eenige semitische volk, dat geprobeerd heeft op deze wijze groote politiek te voeren. Zoo min echter als de eerste methode het geld als factor kan of wil uitschakelen, kan de tweede buiten alle bezit van territorium. Wat echter bij de eene methode het voornaamste is, treedt bij de andere slechts op als aanvulling - zij het dan ook een noodzakelijke en onmisbare aanvulling.

Het is deze tegenstelling, die wij aantreffen bij de Romeinen en de Karthagers, zooals ze voordien heerschte tusschen Karthagers en Grieken.

Het Romeinsche boerenvolk had eeuwenlang zijn bestaan ge- 
vonden in het bebouwen van den grond. Vandaar de waardeering voor het bezit ervan, en de bereidwilligheid om er lijf en leven voor te wagen. De zee echter was en bleef den Romeinen vreemd, en het is niet slechts een gemeenplaats, wat Horatius ${ }^{1}$ ) schreef:

„Illi robur et aes triplex

Circa pectus erat, qui fragilem truci

Commisit pelago ratem

primus ...."

De Karthager echter leefde van en voor den handel over zee; physiek en psychisch was hij daarop ingesteld. Den grond echter, dien men in Afrika verwierf, liet men als latifundia door slaven en Libyers verzorgen ${ }^{2}$ ).

Deze twee staten, zoo geheel verschillend van aard, geraakten na den aftocht van Pyrrhus met elkaar in conflict: de Mamertijnen, die zich op misdadige wijze meester hadden gemaakt van Messina na den dood van Agathokles in 289 en nu in het nauw gedreven waren door Hiero van Syracuse, riepen eerst de hulp van Karthago, later die van Rome in. Karthago zond een garnizoen ter verdediging van de stad, na tusschen den zegevierenden Hiero en Messina, dat op het punt stond zich over te geven, bemiddeld te hebben. Messina verloor hierbij de vroegere bezittingen op Sicilië, maar behield zijn zelfstandigheid (270 of $269 \mathrm{v}$. Chr.).

Deze interventie van Karthago is verklaarbaar door de bezorgdheid, die de toenemende macht van Hiero wekte: Gelo, Dionysius I, Timoleon, Agathokles, Pyrrhus hadden bewezen, dat Syracuse de verdrijving der Karthagers uit geheel Sicilië op zijn program zette, telkens als het, geleid door een sterke figuur, alle andere Grieken op Sicilië naar zijn wil dwong. Hiero mocht vinden, dat de Karthagers hem beroofd hadden van een bijna zekere prooi, hij voelde zich tegen de Karthagers niet opgewassen, en al zou waar zijn, dat hij de Romeinen bij het beleg van Rhegium door het zenden van levensmiddelen gesteund heeft, zooals Cassius Dio meldt ${ }^{3}$ ),

r) Oden I, 3 .

2) Hiermede hangt ook samen de geringe oppervlakte van het grondgebied der Karthagers in Afrika: Kromayer (o.1. p. 242) taxeert tot aan den eersten Punischen oorlog een territorium van \pm 25000 K.M. ${ }^{2}$, d.i. nog geringer dan de oppervlakte van Siciliē.

3) Zonaras VIII I6, I4. 
een bondgenoot kon hij in Rome niet vinden: krachtens het laatste verdrag, in 306 tusschen Karthago en Rome gesloten, werd aan

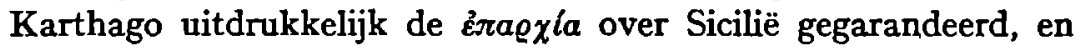
in het verbond tegen Pyrrhus was deze afspraak nogmaals uitdrukkelijk bevestigd ${ }^{1}$ ).

Welke motieven de Mamertijnen later gehad hebben om de Karthagers, die hen in 270 van den algeheelen ondergang gered hadden, als beschermers te willen ruilen voor de Romeinen, is onbekend ${ }^{2}$ ); vast staat, dat zij vermoedelijk 266 of begin 265 , de Romeinen uitnoodigden de bescherming over te nemen. In den Romeinschen senaat was hiervoor geen meerderheid te vinden; de voorstanders brachten hun daartoe strekkend voorstel in de comitia, hoop op stoffelijk gewin bracht de meerderheid op hun hand; het bondgenootschap met Messina werd gesloten, het Karthaagsche garnizoen werd met list en dreigementen weggewerkt. Toen men echter de consequenties uit het verdrag trok en een Romeinsch garnizoen naar Messina wilde overzetten, vereenigden zich Karthago en Hiero tot gewapend verzet: de eerste Punische oorlog was begonnen.

In dit eerste conflict ligt alle schuld en initiatief bij Rome: uitdrukkelijk was in de verdragen vastgelegd, dat aan de Romeinen op Sicilië slechts evenveel was toegestaan als in Karthago: hun activiteit en handel mocht die van een gewonen burger niet over-

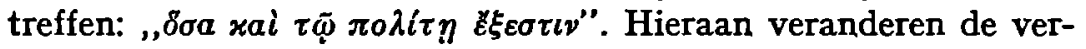
zinsels der Romeinsche annalisten over de verboden inmenging der Karthaagsche vloot in de golf van Tarente niets: verzinsels, die bovendien gebaseerd zijn op een verdrag, dat den Karthagers den toegang tot Italië verbood, zooals den Romeinen het betreden van Sicilië, maar welk verdrag nooit bestaan heeft volgens de uitdrukkelijke bevestiging van Polybius, die den text der verdragen

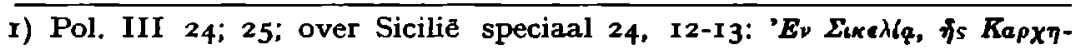

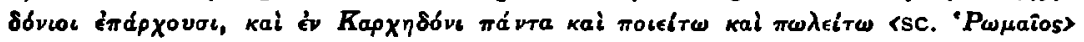

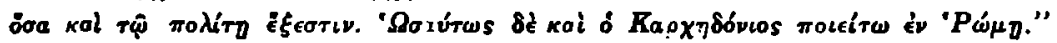

2) Gezien den aard en het verleden der Mamertijnen, lijkt heel aannemelijk de verklaring van De Sanctis (III I, p. 97): „Ma era dominio straniero: e poneva termine per sempre alle loro scorrerie e alle rapine; perchè $\mathrm{i}$ Cartaginesi, popolo civile e commerciante, non avevano interesse a fomentare il brigantaggio, nè volevano, sperando probabilmente, di poter vivere in pace con Ierone, provocar troppo il sentimento nazionale dei Greci". 
met eigen oogen gezien had, en die in dezen niet liegen kon, daar de verdragen, in koper gegraveerd, nog in zijn tijd op het Kapitool bewaard werden ${ }^{1}$ ).

Karthago had alle reden tot gewapend verzet. Het ging hier niet om een factorij of een beperkt handelsgebied: men had gezien hoe Rome in Italië doelbewust na elke verovering verder greep. Men mocht spreken over Messina, over materieel gewin, men moge nu spreken over "Brückenkopf" - Karthago had gezien hoe Rome elke voorpost uitbouwde tot nieuw gebied, en dan weer aanleiding vond verder weg weer een „Brückenkopf” te maken. Er dreigde voor het onontbeerlijke bezit van den westpunt van Sicilië grooter gevaar dan ooit gedreigd had van den meest energieken Griekschen tyran: en vastberadener en hardnekkiger dan ooit hebben de Karthagers zich nu verzet.

Het mocht niet baten: bij den vrede van $24 \mathrm{I}$ verloor men niet alleen Sicilië en de kleinere eilanden, maar men moest 3200 Attische talenten betalen in tien jaarlijksche termijnen. Een uitvloeisel van den ongelukkigen oorlog was de Afrikaansche opstand: pas na drie jaar en vier maanden gelukte het Karthago, zich van de oproerige huurlingen te bevrijden. De daarop volgende roof van Sardinië maakte het nog resteerende handelsgebied nog kleiner; een nieuwe boete van 1200 talenten viel in deze omstandigheden moeilijker dan ooit te betalen. En wat het ergste was: niet alleen de oorlogsvloot, maar ook de handelsvloot was zoo goed als verdwenen: de $\vartheta a \lambda a \sigma \sigma o x \rho a \tau i a$ was overgegaan aan Rome, wellicht als grootste buit. Karthago moest vrijwel van voren af aan beginnen: nieuwe bestaansmogelijkheden moesten gezocht, de nog bestaande uitgebreid en geintensiveerd.

In het Oostelijk deel van het Middellandsche Zeegebied waren de Phoeniciërs begonnen; naar het Westen waren zij gegaan ter uitbreiding en om te vervangen, wat in het Oosten verloren was gegaan; ook hier verdreven, restte er slechts, nog verder Westwaarts te trekken: Hamilcar organiseerde een nieuwe Karthaagsche macht in Spanje.

De nieuwe omstandigheden brachten nieuwe consequenties mee: nu de heerschappij ter zee in handen lag van de Romeinen, was

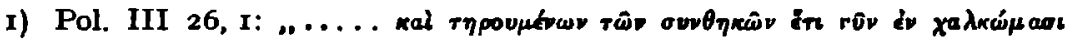

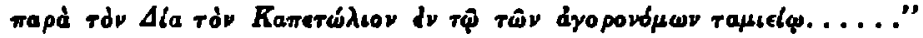


men gedwongen het onbekende te ondernemen: voor het eerst stichtte Karthago een koloniaal rijk, veroverde het grond, onderwierp met wapengeweld andere volkeren. Het deed dit goed: Hamilcar kende het handwerk door zijn succesvollen strijd op Sicilië. In Hasdrubal kennen we weer den sluwen Phoeniciër: voornamelijk langs diplomatieken weg breidt hij het imperium uit. In Hannibal zien we de kwaliteiten van Hamilcar en Hasdrubal vereenigd - beide in zeldzame mate.

Is het dus geen noodzakelijk postulaat voor de Karthaagsche politiek om te herwinnen, wat aan een sterkere macht was afgestaan, is er ook, zooals we in Hoofdstuk III aantoonden, geen enkele daad der drie Karthaagsche veldheeren aan te wijzen, die duidelijk op voorbereiding tot oorlog wijst, zoo zijn er andere feiten, die duidelijk het tegendeel aangeven. Ten eerste: het Ebro-verdrag (zie pag. 56-57). Ten tweede: indien de Barciden werkelijk een oorlog van plan waren, is het onverklaarbaar, dat zij volkomen verzuimd hebben een zoo goed mogelijke vloot te bouwen $\left.{ }^{1}\right)$. De zeevaart verstonden zij uitnemend; soldaten hadden zij in overvloed om de schepen te bemannen en zoo het nadeel in te halen, dat zich in den eersten oorlog tegen de Romeinen juist op dit terrein geopenbaard had; hout en geld leverde Spanje in meer dan overvloedige mate. En toch kan Hannibal bij zijn vertrek naar Italië aan zijn plaatsvervanger Hasdrubal in Spanje slechts een goede dertig schepen achterlaten $\left.{ }^{2}\right) ;$ tien andere heeft Hasdrubal nog gereed weten te maken, en met deze meer dan bescheiden vloot heeft hij dan ook niets uit kunnen voeren.

Een derde argument tegen de aanname van zucht tot oorlog bij Hannibal is gelegen in het beleg van Saguntum. Naar Polybius uitdrukkelijk vermeldt, begon dit beleg in de lente van 219 en duurde 8 maanden ${ }^{3}$ ). Het is onaannemelijk, dat een veldheer, die zulke grootsche plannen heeft, een heel jaar besteedt aan een vesting van zoo gering belang *). Het krijgsplan, dat hij tegen Rome heeft uitgevoerd, berustte geheel op zijn onverwachte komst in

1) Zie o.a. Kolbe: „Die Kriegsschuldfrage”, p. 36.

2) Pol. III 95. Livius XXII 19.

3) Pol. III I5-I7.

4) Zie R. Oehler: „Sagunt und seine Belagerung durch Hannibal. Eine topographische Studie"'. Neue Jahrb. für Philol. I43 (189I) p. 42I-428. 
Noord-Italië: veel heeft er niet aan gemankeerd, of Scipio was hem nog in Gallië tegemoetgetreden. Het oponthoud en het nadeel, zelfs in geval van een overwinning, van een veldslag buiten Italië heeft hij maar amper kunnen ontloopen. Dit risico had hij kunnen vermijden door in 219 direct tegen Italië op te rukken en desnoods het beleg van Saguntum aan een zijner onderbevelhebbers op te dragen. Bij vasten wil tot oorlog immers was de Romeinsche interventie ten Zuiden van den Ebro voorwendsel genoeg - en, wat het voornaamste is: Polybius wijst III 16 op de noodzakelijkheid voor de Romeinen om met Illyrië af te rekenen, alvorens zij Hannibal onder handen konden nemen of ook maar Saguntum konden helpen. Duidelijk is hier sterke overdrijving in het spel: maar voor Hannibal was de illyrische oorlog de prachtigste gelegenheid geweest om de Romeinsche strijdkrachten aan te vallen in een tijd, dat ze reeds door een anderen oorlog in beslag genomen waren. Dat hij hiertoe niet overging, is slechts verklaarbaar hetzij door gebrek aan inzicht - en hiervan moge Hannibal beschuldigen wie dat wil - hetzij door de omstandigheid, dat Hannibal niet à tout prix oorlog zocht, en zelfs terdege rekening hield met de mogelijkheid, dat Rome, nu het er op aankwam, het bij de waarschuwing zou laten en geen oorlog zou wagen. En hieraan heeft, naar de discussies in den Romeinschen senaat ons leeren, dan ook niet veel gemankeerd.

Zocht Karthago macht te verwerven door geld, en geld door handel, en had het hiertoe voldoende, indien het maar afzetgebied vinden kon en de verbindingen over zee op vitale punten onbedreigd kon handhaven, de Romein streefde krachtens zijn afkomst en gewonen arbeid naar het bezit van grond. Dit uitte zich in de verhoudingen onderling: de mate van aanzien was aanvankelijk afhankelijk van de grootte van den akker en de opbrengst ervan; een verhaal als dat over Cincinnatus getuigt nog van de doorwerking dezer opvatting, als de liefde voor het ruwe boerenwerk bij de rijke Romeinen reeds lang verdwenen is. Dit uitte zich ook in de politiek tegenover de naburen: met geweld wordt hun de grond ontnomen, dien men noodig heeft wegens de uitbreiding der bevolking: de eerste en meest primitieve vorm van expansie is daar. In verband met en in dienst van deze expansie staat het streven, 
om zijn wil op te leggen aan naburige en stamverwante steden: Rome wordt het politieke en sacrale hoofd van den stedenbond in Latium, na onttroning en zelfs verwoesting van Alba Longa. Dan richt zich de blik verder: en consequent vasthoudend aan hetzelfde principe worden met behulp van een bondgenootschap met de Samnieten de tusschengelegen Aequi, Volsci en Campani in het nauw gedreven en overwonnen; met hulp van Apulie werden de Samnieten ingelijfd; in verbond met Alexander uit Epirus werd gestreden tegen Samnieten, Apuliers en Lucaniers; na zijn dood zochten de Romeinen zich te verbinden met de Grieksche steden aan de Zuidkust van Italië in den strijd tegen de Lucaniers; het succes in dezen oorlog, dat niet alleen de overheersching scheen te brengen over den vijand, die tusschen het Romeinsche gebied lag en de bondgenooten, maar ook over de bondgenooten zelf (o.m. Thurii kreeg een Romeinsch garnizoen) bracht Rome in conflict met Tarente: het resultaat der methode om, door steeds een verder wonend volk tot bondgenoot te nemen, telkens den nabuur te onderwerpen, werd bijna vernietigd door de komst van Pyrrhus.

Slechts de hardnekkigheid van den senaat en de hier voor het eerst scherp geformuleerde regel om niet te onderhandelen, zoolang de vijand nog gewapend in het gebied stond, bracht Rome uiteindelijk de overwinning en daarmee de definitieve inlijving van midden- en zuid-Italië. Gebruik makend van de onderlinge verdeeldheid der Etruskers hadden de Romeinen ook hier hun gezag uitgebreid en in 285-284 zelfs op de Galliërs groot gebied veroverd. In alle nieuw-verworven streken yerzekerden Romeinsche of Latijnsche kolonies handhaving van de heerschappij.

Het is juist deze kolonisatie-methode die bewijst, dat de oorlogen van Rome niet ten doel hadden beveiliging van eigen gebied of het afweren van den aanvaller: de verwerving van nieuwen grond was de inzet van den krijg; na de overwinning moest het nieuwe bezit veilig gesteld worden. Patriciërs en plebeiërs, nobiles en democraten konden dan gaan vechten aan welke klasse van de Romeinsche bevolking de buit ten goede zou komen.

Het zou onjuist zijn, uit het verloop van de Romeinsche geschiedenis het definitieve resultaat voor te stellen als datgene, wat Rome zich in het begin van zijn ontwikkeling voorstelde: geleidelijk moet zich, met de uitbreiding, ook de blik op de verdere mogelijkheden 
verruimd hebben. Dit geldt zoowel voor de verovering van Italië zelf als voor de vestiging van de wereldheerschappij. Maar op den duur vormde zich in den senaat, door langdurige ervaring geoefend, een systeem van vooruit-zorgen. Nog nauwelijks is het eene succes behaald, of een andere onderneming, voorbereid door diplomatieke actie nog tijdens of zelfs vóór de vorige, wordt uitgevoerd - waarbij dan tevens weer de grondslag wordt gelegd voor wat daarna komen moet. De koppige vastberadenheid en energie gaf nieuwen moed en zelfvertrouwen.

„In het algemeen", zoo zegt Polybius I 37, 7-9, „,behalen de Romeinen, door in alles geweld te gebruiken en in de meening, dat zij hun voornemens noodzakelijk moeten uitvoeren en dat hun niets, van wat ze eenmaal besloten hebben, onmogelijk is, in vele gevallen succes, juist wegens het energiek toepassen van dien stelregel; maar soms lijden zij duidelijk fiasco, en dit wel voornamelijk bij hun pogingen over zee. Te land immers, als zij hun aanvallen richten tegen menschen en menschen-werken, behalen zij meestal goed resultaat, daar zij hun geweld toepassen tegen gelijksoortige krachten, en maar zelden lijden zij daarbij échec". — „Die Römer sind ein rauhes, kriegerisches, eroberungslustiges Volk, das sich nicht begnügt, die Feinde zu unterwerfen; ein groszer Teil der Besiegten wurde vielmehr vernichtet oder vertrieben, und Römische Bürger auf ihrem Lande angesiedelt. So verbreiterten sie das Fundament ihrer Vormachtstellung"' 1).

Rome had de verovering van Zuid-Italië besloten met het beleg van Rhegium; de soldaten van het Romeinsche garnizoen, die zich van de stad meester hadden gemaakt uit vrees voor verraad en nu levend in de handen der Romeinen vielen, werden te Rome more maiorum terechtgesteld als afschrikwekkend voorbeeld.

Hoe kwam men er nu toe om slechts eenige jaren later de Mamertijnen, misdadigers van hetzelfde slag, te gaan helpen?

Op pag. 63-64 zagen we, dat dit ingrijpen der Romeinen op Sicilië onrechtmatig was: men ging een bondgenootschap aan met een stad in het gebied van Karthago, en daardoor ontstond oorlog. Polybius behandelt I Io, 4-II,4 uitvoerig de bedenkingen van den senaat: een verdediging van de Mamertijnen zou, na de officiëele

I) Niese-Hohl: „Grundriss der Röm. Geschichte” \$ p. 87. 
veroordeeling van hun handelwijze door de straf, aan de misdadigers van Rhegium voltrokken, niet goed te praten zijn. Dit is het eenige bezwaar: over bezwaren van schending der verdragen wordt niet gesproken. Wat lokte aan tot ingrijpen?

„Men zag", zoo zegt Polybius, „dat Karthago niet alleen in Afrika, maar ook in Spanje veel onderworpen gebied had, dat het alle eilanden beheerschte in de Sardinische en Tyrrheensche Zee, en vreesde dat, als zij nu ook nog Sicilië zouden overmeesteren, de Karthagers al te lastige en geduchte naburen zouden zijn, daar zij hen overal zouden insluiten en alle deelen van Italië bedreigen. Dat zij Sicilië dra geheel in hun macht zouden krijgen als Messina geen hulp ontving, was duidelijk; want na de bezetting van Messina door de Karthagers zou Syracuse ook spoedig ten prooi vallen: en daarmee hadden de Karthagers als het ware een brug om naar Italië over te steken. Lang delibereerde de Senaat; ten slotte won de overweging van fatsoen en men gaf Messina prijs. De volksvergadering ging hiermee echter niet accoord en droeg den consuls op troepen naar Sicilië te brengen tot bescherming van de stamverwante Mamertijnen; het volk handelde zoo uit hoop op materieel gewin".

In deze gedrongen redeneering worden enkele feiten verdrongen: in 270 of 269 komt het Karthaagsch garnizoen in Messina, in 264 de Romeinsche interventie. In 270 had Karthago vrede gesticht tusschen Messina en Syracuse: gedurende zes jaar was Syracuse dus vrij gebleven van de Karthaagsche aanvallen, waarvoor de Romeinen zoo bezorgd waren. Daar Karthago reeds lang onbetwist de hegemonie ter zee bezat en vele steunpunten op Sardinië en Sicilië, behoefde het voor een aanval op Italië niet op Messina of Syracuse te wachten. Ook Rome kende de typisch-Karthaagsche handelspolitiek: voor het bezit van den Italischen bodem viel niets te duchten. Ook overigens is de redeneering van Polybius niet volledig. Immers, indien er in den Senaat lang gedebatteerd is, moeten er Senatoren zijn geweest, die vóór interventie op Sicilië waren. Ongetwijfeld bleven zij in de minderheid, brachten toen hun voorstel in de volksvergadering en wisten het volk te winnen door te wijzen op materieel voordeel. Dat Rome den oorlog met Karthago aanging om dit materiëele voordeel, is dus slechts ten deele juist: de Senatoren, die de drijvers waren, hadden andere 
bedoelingen. De politiek, die de Senaat reeds eeuwen voerde, was politiek van expansie: dienaangaande kan de verdeeldheid niet geheerscht hebben; slechts hierover heerschte verschil van meening, in welke richting men zou uitbreiden, nu in het Zuiden de zee bereikt was, en over de opportuniteit. De Romeinen hadden reeds een handelsvloot, al was de omvang ervan vermoedelijk nog niet groot; zelfs een oorlogsvloot was er, getuige het conflict met Tarente in 282 om de overval op het Romeinsche eskader in de golf van Tarente. De inlijving van de Grieksche havensteden had een mooie gelegenheid geschapen om den zeehandel uit te breiden: men had én materiaal én deskundige onderdanen gekregen. Ongetwijfeld zijn de Senatoren, die hier hun finantiëele belangen hadden, ook die Senatoren geweest, die het minst met de kwestie van fatsoen te doen hadden en het meeste gevoel toonde voor de arme, bedreigde, stamverwante Mamertijnen. De onvolledigheid der bronnen maakt het onmogelijk de motieven der Senatoren, die tot den oorlog hebben gedreven, zuiver vast te stellen: voor de richting van de Romeinsche politiek spreken echter volkomen duidelijk de volgende, vaststaande feiten:

$I^{\circ}$. Indien de Karthagers bedoelingen hadden gehad met Messina, zooals de Romeinen die voorgaven, hadden zij zich zeker op meer doeltreffende wijze van Messina verzekerd dan door een zwak garnizoen. Er waren modi te vinden om in elk geval zooveel invloed uit te oefenen in de leiding van de stad, dat er nooit een gezantschap naar Rome gestuurd kon worden.

$2^{\circ}$. Er was vrede tusschen Messina, Syracuse en Karthago: de Mamertijnen werden dus niet bedreigd: de bezetting door het Karthaagsch garnizoen duurde reeds vijf jaar.

$3^{\circ}$. De z.g. angst der Romeinen voor een Karthaagschen inval in Zuid-Italië vanuit Sicilië wordt door geen enkele Karthaagsche daad gemotiveerd.

$4^{\circ}$. De Romeinsche interventie op Sicilië was schending der verdragen; Rome was er zich van bewust, dat Karthago deze schending en de smadelijke behandeling van het garnizoen niet ongestraft kon laten passeeren.

$5^{\circ}$. Onbewijsbaar is de stelling, dat Rome aanvankelijk slechts Messina als voorpost ter grootere veiligheid wilde bezetten. Bij de beraadslagingen in den Senaat speelde volgens Polybius de over- 
weging een groote rol, dat Sardinië en Korsika Karthaagsch waren $\left.{ }^{1}\right)$; reeds in $259-25^{8}$ is verwoed om het bezit van die eilanden gestreden, en onder de voorwaarden, door Regulus in 256 gesteld, was ook: de afstand van Sardinië ${ }^{2}$ ). De theorie van Täubler ${ }^{3}$ ), dat pas tusschen 241 en 238 te Rome het inzicht rijpte, dat deze eilanden noodzakelijk waren voor de geopolitieke eenheid, blijkt in het licht van deze feiten onhoudbaar.

De tegengestelde fout zou zijn om te beweren, dat de oorlog ondernomen is met de bedoeling om ook deze eilanden te veroveren: ongetwijfeld moest men eerst zien, welke wending de zaken nemen zouden, om dan naar omstandigheden te handelen; politiek blijft nu eenmaal de tactiek van het bereikbare "). Maar dat die eilanden reeds in de beraadslagingen vóor den oorlog een rol speelden, is veelzeggend. In 24I durfde men blijkbaar de eischen niet te hoog stellen, daar ook de Romeinsche staat volkomen uitgeput was. Pas als Karthago door de verliezen, in den Afrikaanschen oorlog geleden, zich in geen enkel opzicht meer kan verzetten, werd ook dit steunpunt voor den Karthaagschen zeehandel geroofd. Uit de daden der Romeinen blijkt duidelijk, dat het in $24 \mathrm{I}$ en 238 bereikte minstens reeds in de eerste jaren van den oorlog als doel gesteld werd.

$\mathrm{Na} 238$ bleef Rome formeel controle uitoefenen over Karthago: de Romeinsche commissie van 23 is er het duidelijkste bewijs van ${ }^{5}$ ). Hier treedt klaar het streven van Rome aan den dag om den eenmaal geslagen vijand niet meer los te laten: expansiepolitiek vergt

I) Zie p. 69.

2) Cassius Dio, fr. 43, 24 (p. 162-163 Melber), over de onderhandelingen

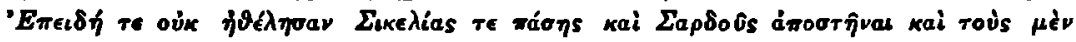

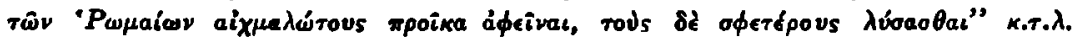
Hiermee zijn de algemeene gegevens van Pol. I 36, 6-8 en Diodorus XXIII, 12 in overeenstemming.

3) „Die Vorgeschichte". Zie boven p. 10.

4) Pol. I 20, I-2 na de verovering van Akragas in 262 waren de Rom. sena-

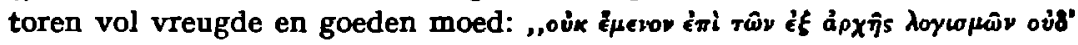

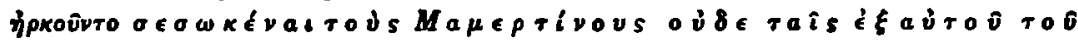

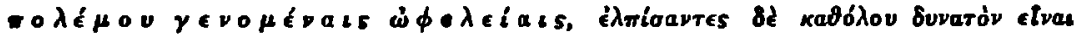

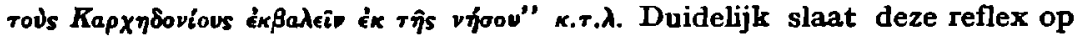
de motieven, die in de volksvergadering naar voren waren gebracht, niet op den gedachtengang der Rom. senatoren daarvór.

5) Zie boven p. 55 . 
nu eenmaal, dat men andere naties zoo zwak en afhankelijk mogelijk houdt. Hamilcar kon op de inmenging der Romeinen in zuiver interne aangelegenheden van den Karthaagschen staat niets dan een uitvlucht stellen - al was die uitvlucht dan ook Phoenicischgeslepen en ad rem - en dit feit werpt een helder licht op de Romeinsche methoden. Polybius verzwijgt ook hier essentiëele dingen: hij vermeldt het Romeinsche gezantschap van 231 niet, wat beslist niet de eenige daad der Romeinen is geweest: Livius zegt XXI I, 3 dat de Puniërs verontwaardigd waren: „quod superbe avareque crederent imperitatum victis esse". Hoewel we door de onvolledigheid en het opzettelijk verzwijgen der bronnen niet meer feiten kennen, kunnen we ook bij Polybius de bevestiging vinden van het feit, dat deze zin van Livius geen rhetorische makelij bevat, maar

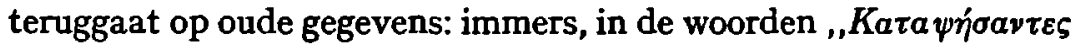

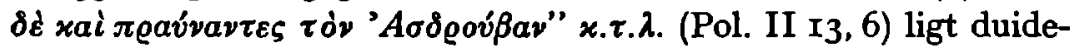
lijk opgesloten, dat de Romeinen, in 226 tot concessies en vriendschap bereid, veel uit het verleden goed te praten hadden ${ }^{1}$ ).

In denzelfden tijd legde Rome ook in de Adriatische Zee, waar het door de stichting van kolonies aan de kust (Castrum Novum en Sena Gallica in 283, Ariminum in 268, Firmum 264, Brindisium 244) reeds lang belangen had, de basis voor zijn hegemonie. In Illyrië had koning Agron een aanzienlijk rijk gesticht; steunend op het bondgenootschap met Macedonië veroverde hij steeds nieuwe steden, ook ten Zuiden van zijn rijk: de Epiroten en Akarnaniërs sloten na vergeefschen strijd bondgenootschap met Teuta, die den intusschen gestorven Agron ( \pm 23I) opgevolgd was. De vroegere bondgenooten van de Illyriërs en Akarnaniërs, de Aetoliërs en Achaeërs, werden hierdoor hun vijanden. De Illyriërs, die de hoofdstad der Epiroten, Phoenice, als basis voor hun vloot gebruikten, oefenden in de Adriatische Zee onbestreden heerschappij uit, wat bij deze volkeren gepaard ging aan zeerooverij. Sinds de consolideering van het bezit van Midden- en Zuid-Italië voeren ook Romeinsche kooplui langs de oostkust van hun land: ook zij werden slachtoffers van de Illyrische piraten. Klachten in den Senaat baatten aanvankelijk niet: pas na den dood van Agron, toen een vrouw op den troon kwam als regentes over een minderjarig kind van Agron, stuurde de Senaat een gezantschap op

I) Zie ook infra, P. 76. 
onderzoek uit. Teuta antwoordde den gezanten, dat de Illyrische staat zich zou hoeden voor onrecht jegens de Romeinen, maar dat zij voor alle Illyrische piraten in het bijzonder niet kon instaan: een opvatting van de zeerooverij als beroep dus, welke nog vele eeuwen onveranderd bij tal van naties zou blijven bestaan. Op dreigende taal der Romeinen reageerde Teuta met schending der onschendbaarheid der gezanten: de casus belli was gevonden.

Nauwkeurig heeft Rome den tijd voor zijn ingrijpen gekozen: in Illyrië heerschte een vrouw, en het bondgenootschap met Macedonië, waarop de Illyrische macht goeddeels steunde, was momenteel waardeloos, want vóór het Romeinsche ingrijpen was Demetrius van Macedonië gestorven; zijn opvolger was onmondig, in Macedonië ontstond verdeeldheid. De geweldige overmacht, waarmee Rome in de Adriatische Zee verscheen, maakte spoedig een einde aan allen weerstand, en ook hier legde Rome den grondslag voor verdere ondernemingen door Corcyra, Apollonia, Epidamnus, de Atintani en Parthini in het rijk als bondgenooten op te nemen. Hierdoor, en door de bepaling dat nooit meer dan twee Illyrische schepen gelijktijdig zich ten Zuiden van Lissus mochten begeven, was ook in deze zee de Romeinsche suprematie gevestigd.

Dat Rome zich tegen de Illyriërs verzette, toen zijn schepen geplunderd werden, is in deze kwestie geheel normaal; Teuta heeft door de schending van het volkerenrecht een onbetwistbare aanleiding tot den oorlog gegeven. De opzet tot expansie der Romeinen blijkt echter ook hier: het tijdstip, dat de Romeinen afgewacht hadden, was uiterst gunstig, en niet toevallig; de taal, die L. Coruncanius tegen de koningin gebruikte ${ }^{1}$ ), verraadt duidelijk, dat hij overtuigd was van een Romeinsche expeditie; men bepaalde zich niet tot de zuivering van de zee, maar men interesseerde zich ook in het Grieksche gebied: dat men dit erkend wilde zien, blijkt uit het feit, dat consul Postumius na den vrede de overeenkomst met Illyrië aan de Aetoliërs en Achaeërs bekend liet maken. Het eerste Romeinsche gezantschap, dat kort daarop naar Athene en Korinthe gezonden werd, bewijst dat de Romeinsche actie zich geenszins tot de Westkust van Griekenland beperkt wilde zien. Sinds den

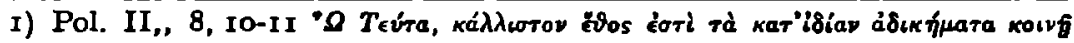

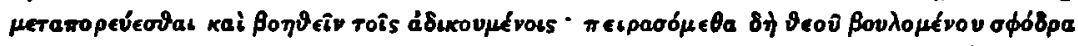

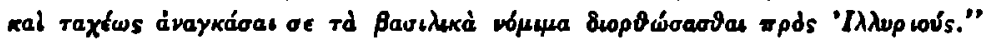


dood van Alexander den Groote hadden de nieuwe rijken in het Oostelijke deel van het Middellandsche Zee-gebied om het bezit van Griekenland gestreden, steeds onder het voorwendsel: de bevrijding van Hellas. Nu schaarde ook Rome zich in deze rij - en weldra met succes.

J. Kromayer ${ }^{1}$ ) verklaart deze expansie van Rome naar Griekenland als volgt: „Es ist ein Gesetz, tief im Inneren des Herzens und Geistes -wenigstens unserer europäischen Rasse - geschrieben, dasz sie vorwärts will, der Kultur entgegen, und um so ungestümer natürlich, je unmittelbarer ihr eine höhere Kulturwelt bei einem benachbarten Volke nahegerückt ist, ein Gesetz, das deshalb in der Geschichte auch überall in die Erscheinung tritt und mit elementarer Gewalt wirkt. Es ist dasselbe Gesetz, das einst die Perser and die Völker des Nordens in die babylonische Kulturwelt hinabgeführt hat, das die Gallier nach Griechenland und Kleinasien, die Germanen ins römische Reich und die Kaiser des Mittelalters nach Italien gezogen hat; das Gesetz, das immer und überall die Völker niederer Kulturstufen in oft unverstandenem Drange nach den Brennpunkten höherer Lebenshaltung und Zivilisation hinzieht".

Dergelijke algemeenheden hebben een zekere aantrekkingskracht: maar in den grond geven die vage beweringen over "die unwiedersteheliche Kraft" geen verklaring voor de feiten: de tocht der Galliërs naar Griekenland en Klein-Azië had plaats, omdat Italië hen op den duur met succes tegenhield, en de Galliërs hun heil dus wel elders moesten zoeken; men kan echter moeilijk zeggen, dat \pm 400 v. Chr. ,hoogere cultuur" Noord- en Midden Italië zoo begeerenswaardig maakte. Livius ( $\mathrm{V}$ 33, 2-3) spreekt dan ook vrij wat nuchterder: „Eam gentem traditur fama dulcedine frugum maximeque vini, nova tum voluptate, captam Alpes transisse agrosque ab Etruscis ante cultos possedisse; et invexisse in Galliam vinum inliciendae gentis causa Arruntem Clusinum" e.q.s. De neiging echter om over anderen te heerschen en zijn goederen te rooven, is in den mensch aanwezig: waar een hooger levenspeil en meer rijkdom gezien wordt, is de aantrekkingskracht natuurlijk het grootst- en vaak wegens de verweekelijking en armoede aan kinderen de weerstand het $z$ wakst: dan gaat de uitbreiding automatisch langs den weg van den geringsten weerstand. Voor Rome I) „Roms Kampf um die Weltherrschaft”. Leipzig I9I2, p. I3. 
gaat de verklaring van Kromayer zeker niet op: de verovering van de rest van Europa wordt er geenszins door verklaard!

Daar de stichting van de heerschappij ter zee en de eerste Punische oorlog langen tijd alle krachten van Rome in beslag nam, had de expansie in Noord-Italië al dien tijd stil gestaan. De coalitie der cisalpijnsche Galliërs, die, versterkt met transalpijnsche stamverwanten, in 238 tegen de Romeinen optrokken, maar bij Ariminum door onderlinge tweedracht omkwamen, herinnerde de Romeinen echter duidelijk aan het schrikkelijke gevaar, dat hen steeds vanuit het Noorden bedreigde. Toen Rome zich langzamerhand herstelde van de verliezen, in den Punischen oorlog geleden, gingen er stemmen op om den Ager Gallicus, reeds in 285-284 veroverd, met Romeinsche kolonies te bezetten. Ondanks het verzet der nobiles, die de voordeelen van de staatsdomeinen liever aan hun eigen kaste zagen komen, bewerkte de democraat C. Flaminius in 232, dat het land onder Romeinsche burgers, plebejers als kolonisten, verdeeld zou worden.

De Galliërs echter, speciaal de naburige Boi, die wisten wat dergelijke kolonisatie beoogde en beteekende, voelden zich in hun bestaan bedreigd. Het ging nu niet meer om de hegemonie, maar om

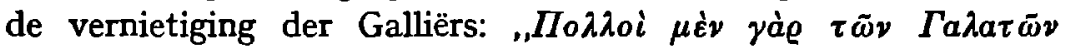

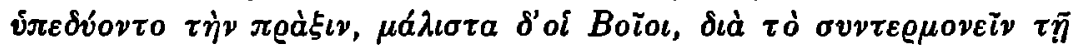
$\tau \tilde{\omega} \nu$ 'P

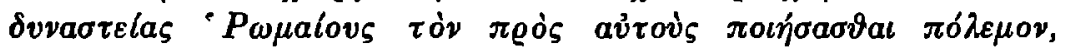

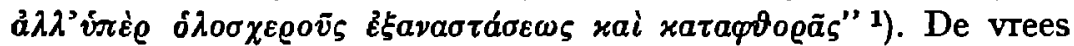
der Galliërs, die de methoden der Romeinen ondervonden en ook op anderen toegepast gezien hadden, is het beste bewijs, dat onze pag. 67 gegeven opvatting der bedoeling van de Romeinsche kolonisaties juist is.

De Galliërs in Noord-Italië vormden een nieuwe coalitie, zochten en vonden weer hulp bij de transalpijnen. Geweldig was de macht, die tegen de Romeinsche bedreiging op de been werd gebracht: opnieuw zou Rome door de Galliërs vernietigd worden. In dezen nood onderzochten de Romeinen, waarop ze ter verdediging konden rekenen: alle bondgenooten moesten nauwkeurig hun aantal weerbare mannen opgeven; groote hoeveelheden oorlogsmateriaal en levensmiddelen werden opgeslagen: men rekende op een lang-

I) Pol. II 2I, 9. 
durigen en zwaren oorlog. Ook naar de landen buiten Italië richtte men den blik, vanwaar hulp, vanwaar gevaar kon komen.

Intusschen had Hasdrubal, sinds 229 de opvolger van den gesneuvelden Hamilcar, de Karthaagsche macht in Spanje sterk uit-

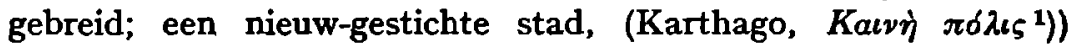
diende als militair en civiel centrum. Blijkbaar hadden de Romeinen de laatste jaren de controle gestaakt: Polybius vertelt althans, dat de Romeinen versteld stonden over de macht en welvaart der Karthagers in Spanje en bevonden, dat zij in de afgeloopen jaren

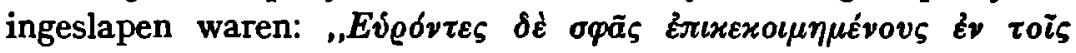

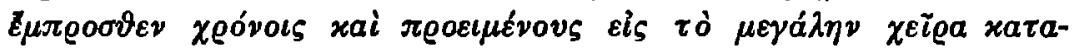

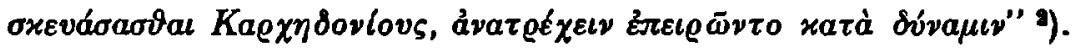
Uitdrukkelijk vermeldt Polybius hier als vanzelfsprekend, dat Rome wilde probeeren, om de uitbreiding van de Karthaagsche macht met alle kracht tegen te gaan. En welke methode is volgens dien-

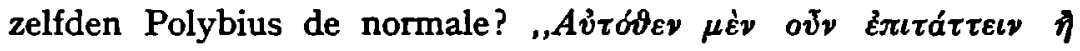

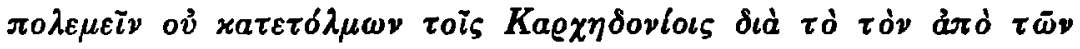

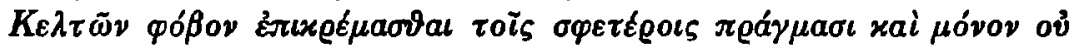

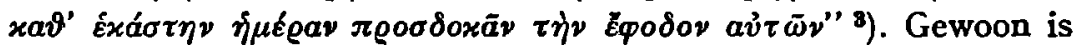
dus, dat een souvereine staat aangaande zijn eigen zaken in eigen imperium een bevel van Rome krijgt tot inperking of - oorlog. Wegens het groote gevaar der Kelten, die dreigen Rome te gaan vernietigen, wordt nu deze methode niet toegepast: men vleit en streelt Hasdrubal: het Ebro-verdrag wordt gesloten, het gevaar voor gemeenschappelijk handelen der Kelten en Karthagers is afgewend.

Nu Polybius zoo duidelijk zegt, wat er gebeurd zou zijn, indien de Romeinen de handen vrij gehad hadden, is ook duidelijk, wat er geschied is, toen het gevaar, dat van de Kelten gedreigd had, overwonnen was. Men leze de geciteerde passage van Polybius en

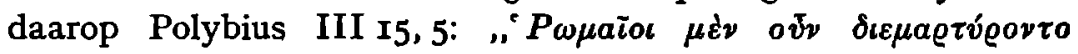

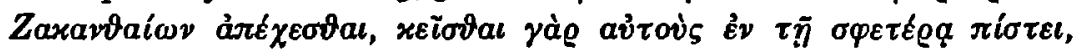

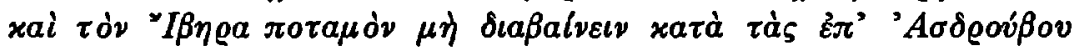

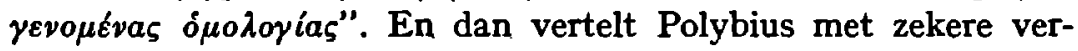
bazing en misprijzen, dat Hannibal kwaad werd!
1) Karthago= Qart-Chadascht = NieuweStad:Ehrenberg,,,Karthago", p.13.
2) Pol. II 13,4.
3) Ibidem 5 . 
$\mathrm{Na}$ drie zware veldtochten waren de Kelten in Noord-Italië definitief verslagen: de stichting van de kolonies Mutina, Placentia en Cremona vormde weer nieuwe, vooruitgeschoven posten ter beveiliging van het nieuwe gebied en ter verdere uitbreiding, welke dan ook na het einde van den tweeden Punischen oorlog gevolgd is. Practisch was nu geheel het Italische schiereiland aan Rome onderworpen, al restte er nog veel te doen voor versterking en intensiveering van de macht. Onderworpen waren Sardinië, Corsika, Sicilië en de kleinere eilanden; de Romeinsche vloot beheerschte het Westelijk deel der Middellandsche Zee; de Adriatische Zee was Romeinsch, en in West-Griekenland had men reeds enkele steunpunten: verdere uitbreiding was slechts mogelijk in Spanje en in Griekenland. Wat Rome in Spanje van plan was, vertelde ons Polybius zoo juist (pag. 76); maar toen in 220 de eerste stappen gezet waren, en door het eerste gezantschap naar Hannibal de grondslag voor het conflict gelegd was, kwamen er moeilijkheden in het Oosten, of liever, kwam er een goede gelegenheid de reeds eenigen tijd bestaande moeilijkheden op te lossen.

Antigonus Doson, de regent van Macedonië, had na de ordening van den toestand in eigen land, krachtens de traditioneele politiek getracht geheel Griekenland te onderwerpen, en met succes: de Achaeische bond en bijna geheel de rest van den Peloponnesus erkende zijn leiding. Zelfs Demetrius van Pharus, die als belooning voor zijn verraad jegens Teuta in den eersten Illyrischen oorlog en voor de hulp aan Rome verleend, aanzienlijke gebiedsuitbreiding op kosten van de Epiroten en Illyriërs had gekregen, was naar de Macedonische partij overgeloopen; hij durfde dit doen, daar de Romeinen den Gallischen oorlog moesten voeren ${ }^{\mathbf{1}}$ ). Hij overviel steden aan de illyrische kust; zijn vloot maakte de zee onveilig. Hieraan moesten de Romeinen een eind maken: hun overzeesch gebied liep gevaar. Maar eenvoudig was de zaak niet: men zou rekening moeten houden met Macedonië, dat door middel van Demetrius den machtigen concurrent uit Griekenland trachtte te verdrijven. Voor hem op hun hoede hebben de Romeinen zich blijkbaar onthouden van actie tegen Demetrius: dat deze reeds lang bezig was, blijkt uit de motiveering, die Polybius uitdrukkelijk geeft: Demetrius meende de Romeinen te kunnen minachten wegens

1) Pol. III, 16, 2-3. 
het gevaar, dat hen van de Kelten dreigde, en daarop wegens het gevaar, dat hen van de Karthagers te wachten stond. Ook hier immers gingen de zaken niet naar wensch: Hannibal had zich niet laten intimideeren, en, indien waar zou zijn, dat men in Rome rekening gehouden had met de mogelijkheid dat de jeugdige Karthager niet of nog niet dezelfde capaciteiten zou hebben als zijn voorgangers, wist men sinds het eerste gezantschap wel, dat Hannibal en zijn macht niet onderschat mochten worden. Een dubbelen oorlog te beginnen leek gevaarlijk.

Weer was het geluk met Rome. Antigonus van Macedonië stierf, de jeugdige Philippus kreeg den z.g. bondgenooten-oorlog te voeren. Daardoor werd de illyrische oorlog tot een ongevaarlijke strafexpeditie. Toch lieten de Romeinen de zaken in Spanje voorloopig op hun beloop: dat hiervan Saguntum de dupe kon worden, was te voorzien, maar niet te veranderen: de provocatie was geschied, en de Saguntijnen hadden er hun eigen rol in gespeeld. Bovendien was de Senaat, waarvan natuurlijk minstens de meerderheid tot het eerste gezantschap naar Hannibal besloten had, nog lang niet unaniem van oordeel, dat men het in Spanje ook tot oorlog moest laten komen.

Zooals in den eersten Illyrischen oorlog vielen de Romeinen de Illyriërs met groote overmacht aan: binnen een jaar tijd was het pleit beslecht: Demetrius vluchtte naar Macedonië, zijn gebied werd deels ingelijfd, deels onder de aanhangers van Rome verdeeld ${ }^{\text {'). }}$.

I) M. Holleaux (,,Rome, la Grèce et les Monarchies Hellénistiques au III siècle avant J.C." Parijs I92 I) behandelt Hoofdstuk IV, p. I3o ssqq. de verhouding van Rome tegenover Mlyrie. Volgens hem hebben de Romeinen geen aspiraties gehad om hun macht in Epirus of Griekenland te vestigen (p. 125) of uit te breiden (p. 13I). Ziehier een voorbeeld van zijn bewijsvoering: „De Romeinen zijn sinds 228 niet meer in Illyrie opgetreden, en Demetrius van Pharus heeft zich van Rome losgemaakt en zich aangesloten bij Antigonus van Macedonie, Rome's tegenstander: „Polybe pense en donner la raison. Démétrios, dit il, commença de „dédaigner les Romains" quand il les vit attaqués par les Gaulois. Mais l'explication est peu satisfaisante. La guerre celtique, nous l'avons dit, tourna toute de suite à l'avantage de la République; et, du reste, nous l'avons dit aussi, comment l'aurait-elle empêchée de faire usage de ses flottes? Une action vigoureuse de la marine romaine sur les côtes dilllyrie, une attaque dirigée contre Pharos...." Men ziet, anders dan de Romeinen en al hun bondgenooten, oordeelt Holleaux het Keltengevaar zoo gering, dat men er gerust een oorlog aan ver- 
Intusschen was Saguntum, door de Romeinsche provocateurs in den steek gelaten, na een beleg van acht maanden gevallen. Opnieuw kwam nu de Spaansche kwestie in den Senaat: als de redevoeringen bij Cassius Dio (fr. 54, I-8, p. I96-r99 Melber) nog de oorspronkelijke strekking bewaard hebben, werd er niet gedebatteerd over recht, maar over het nut en het gevaar van den te ondernemen oorlog. Cornelius Lentulus stelde oorlogsverklaring en directen aanval voor; $Q$. Fabius Maximus hield blijkbaar nog rekening met de mogelijkheid dat Karthago, nu het Rome zeer machtig en onbedreigd zag, zou zwichten: in elk geval kon men door bedachtzaamheid en onderhandelingen het odium van den oorlog op de tegenpartij schuiven. $\mathrm{Zijn}$ voorstel werd aangenomen - maar leidde tot oorlog.

Vatten wij de resultaten van ons onderzoek nog eenmaal samen, dan zien wij: aan den eenen kant Karthago, een phoenicische kolonie, door aard en traditie strevend naar geld. Tot aan den eersten Punischen oorlog hadden de Karthagers met Rome in vriendschap samengewerkt: zij konden dat doen wegens de belangengemeenschap. Het eerste conflict ontstond om het bezit van Sicilië, een eiland, dat de Karthagers om hun handel en heerschappij ter zee aan geen machtigen vijand over konden laten, en waarover reeds eeuwen gestreden was, telkens n.l. als het bezit van de gewichtige westkust in gevaar kwam. Niet te betwisten is de onrechtvaardigheid van de Romeinsche interventie in Messina: het gaat niet aan in het gebied van een anderen staat een bondgenootschap te sluiten, en dan aan dit bondgenootschap rechten te ontleenen, die inderdaad erkend zouden moeten worden, indien het bondgenootschap zelf rechtmatig was.

Na het verlies van den oorlog, gevolgd door den roof van Sardinië, trekt Karthago de consequenties uit den nieuwen toestand: de zee wordt verlaten, men sticht een koloniaal rijk in Spanje. Hier is inderdaad bewuste expansie; maar ook hier kan geen enkele daad aangetoond worden, die de idee van revanche tegen Rome bewijst,

binden kon tegen Demetrius, toen bondgenoot van Macedoniē; en dat de Keltenoorlog (225-222) „toute de suite tourna en avantage de la République" kon Demetrius vooruit weten? Zoo wordt een mededeeling weggeredeneerd van Polybius, die, naar bekend is, voor de periode van den Gallischen oorlog Fabius Pictor tot bron had! 
veeleer het tegendeel. Voor een bepaalde periode moge men aan onmacht denken - voor het jaar $\mathbf{2 2 6}$ geldt dit zeker niet. In Spanje zelf kon men met Rome niet in conflict komen, daar Rome hier geen meter grond bezat. Elders bleven de Karthagers weg. Eerst als Rome provoceert door het verbond met Saguntum te sluiten, stuit het op verzet: in het bewustzijn van zijn kracht duldt de Karthaagsche staat - en niet alleen Hannibal - geen inmenging. En terecht: want hier ging het om het heele bestaan. Men kende de Romeinsche methode: de vestiging in een nieuw gebied mocht aanvankelijk klein schijnen, elke gelegenheid tot uitbreiding werd uitgebuit, totdat het geheele land veroverd was.

Aan den anderen kant staat Rome, eens een nederzetting van landbouwers, afhankelijk van een vreemde mogendheid. Door veroveringsoorlogen groot geworden, zet het in 264 alle bezwaren van recht en verdragen ter zijde en begint den eersten Punischen oorlog. In $238 / 7$ voltooit het door den roof van Sardinië, waarvoor zelfs Polybius slechts felle veroordeeling heeft, de veroveringen, zooals men zich die reeds uiterlijk in het begin van den oorlog had voorgenomen. De zucht tot expansie brengt het dan achtereenvolgens in conflict met Illyrië, de Galliërs, weer de Illyriërs. Diezelfde drang naar expansie is dan ook de eenige verklaring van de absoluut onrechtmatige provocatie in Spanje, en daarmee van de oorzaak en schuldvraag van den tweeden Punischen oorlog. 


\section{LITTERATUUR ${ }^{1}$ )}

Niebuhr: „,Vorträgen über Römische Geschichte”. Herausgeg. von M. Isler.

II. Berlijn 1848 .

Hennebert: „Histoire d'Annibal". Parijs I87o.

Soltau: „De fontibus Plutarchi in bello Punico enarrando”. Diss. van Bonn. 1870 .

O. Gilbert: „Rom und Karthago in ihren gegenseitigen Beziehungen. 513-536 u.c." Leipzig 1876 .

A. v. Breska: „Untersuchungen über die Quellen des Polybius im dritten Buch". Berlijn r880.

Neumann-Faltin: „Das Zeitalter der Pun. Kriege”. Breslau 1883.

EgelhanfF: „Analekten zur Geschichte des zweiten Punischen Krieges". Histor. Zeitschr. N. F. XVIII (I885) 53 e B.

Mommsen: „Römische Geschichte” I.

Ofhler: „Sagunt und seine Belagerung durch Hannibal. Eine topographische Studie". Neue Jahrb. f. Phil. I43 (1891).

Thiaucourt: „Les Causes et l'Origine de la seconde guerre punique". Parijs I893.

J. Fuchs: „Der zweite Pun. Krieg und seine Quellen”. Wiener Neustadt 1894. Meltzer: „Geschichte der Karthager” I 1877; II 1896. Berlijn.

H. DelbrücK: „Geschichte der Kriegskunst” I. Berlijn 1900.

J. Beloch: „Griechische Geschichte” III I en 2. Straatsburg 1904.

K. Lehman: „Die Angriffe der drei Barkiden auf Italien”. Leipzig 1905.

U. WilckeN: „,Ein Sosylosfragment in der Würzburger Papyrussammlung”"

Hermes 4I (1906).

Kromayer: „Hannibal als Staatsmann”. Hist. Zeitsch. I03 (I909).

Lenschau: Real Enz. von Pauly-Wissowa VII, p. 2323. s. v. Hannibal.

VEITH in Kromayer-Veith: „Antike Schlachtfeldern". III. Berlijn I9I2.

Kromayer: „Roms Kampf um die Weltherrschaft”. Leipzig I9r2.

REID: „Problems of the second punic war". Journal of Roman Studies III (I9I3).

KanRSTEDT: „Meltzer: Geschichte der Karthager" III. Berlijn I9r3.

E. MEYer: „Untersuchungen zur Geschichte des zweiten Pun. Krieges” in "Sitzungsberichten der Kön. Preuss. Akad. für Wissenschaften". 2e Halbband. r9r3. p. 688 ssqq.

I) Op volledigheid wil deze lijst geen aanspraak maken: de litteratuur is daarvoor te uitgebreid. Ik hoop niets overgeslagen te hebben, dat werkelijk nieuws bevat. Veel werken, die in geen der Nederlandsche Universiteitsbibliotheken aanwezig zijn, laat ik onvermeld. 
E. NORDEN: „Ennius und Vergilius”. Berlijn 1915.

Dessau: „Ueber die Quellen unseres Wissens vom zweiten punischen Krieges". Hermes LI (1916), p. 355 ssqq.

G. DE SANctrs: „Storia dei Romani” III I en 2.

Drachmann: „Sagunt und die Ebrogrenze" in: Danske Videnskab. Selskab. hist. philol. Meddelelser III 3. 1920.

Holleaux: „Rome, la Grèce et les monarchies Hellénistiques au III siècle a. J.C." Parijs I92I.

TÃubler: „Die Vorgeschichte des 2. punischen Krieges”. Berlijn 192 I.

E. MEYer: „Hannibal und Scipio" in „Meister der Politik" I 2e Uitg. 1923, p. 97 ssqq.

P. SchNabel:, ,Zur Vorgeschichte des zen Punischen Krieges", Klio XX (1926)

WeRner Schur: „,Scipio Africanus und die Begründung der römischen Weltherrschaft". Leipzig I927.

E. PaIS: „Storia di Roma durante le guerre Puniche" I en II. Rome 1927. EhrenberG: „Karthago”. Beihefte zum „Alten Orient”. Heft 14. Leipzig 1927.

M. Clerc: „Massalia. Histoire de Marseille dans l'antiquité des origines à la fin de l'empire romain d'occident". I 1927; II 1929.

St. Gsell: „Histoire ancienne de l'Afrique du Nord”. III (1920, 2e druk 1928).

Tenney Frank, Scholten en Hallward in VII en VIII van de Cambridge Ancient History. 1928-1929.

E. Groag: „Hannibal als Politiker”. Weenen 1929.

PhIlIPp: In Real Enz. v. Pauly-Wissowa XIV (1930), p. 2130 ssqq. s. v. Massalia.

W. Oтто: „Eine antike Kriegsschuldfrage”. Hist. Zeitschr. 145, r931.

T. Oertel: „Der Ebrovertrag und der Ausbruch des zweiten Punischen Krieges". Rhein. Museum N.F. 8I (1932).

P. Treves: „Le origine della seconda guerra punica” in: Atena e Roma XIII. 1932.

L. Paretr: „Ancora sulle cause della seconda guerra Punica". Ibidem p. 39-43.

C. Scano: „Di un storico cartaginese" in „Historia Studi Storici per l'antichità classica" VII (1933).

M. Gelzer: „Römische Politilk bei Fabius Pictor” in Hermes 68 (1933).

W. KolbE: ,Die Kriegsschuldfrage vom 218 v. Chr. Geb." in ,Sitzungsber. der Heidelb. Akad. für Wissensch.". Freiburg 1934. 




\section{STELLINGEN}

I

De bewering van Polybius (III 9,6), dat de wrok der Barciden de oorzaak is geweest van den tweeden Punischen oorlog, is onjuist.

\section{II}

Ten onrechte meent E. Norden, dat reeds Ennius in zijn Annalen intriges der Karthagers op Sardinië vermeldde voor de jaren 237-230 v. Chr.

E. Norden: „Ennius und Vergilius". Berlijn r915.

III

De meening van Cicero, dat Ennius den eersten Punischen oorlog in zijn Annalen oversloeg, daar deze reeds door Naevius behandeld was, is aanvaardbaar.

\section{IV}

De bijnaam Censorius van L. Calpurnius Piso is niet als synoniem met den tweeden bijnaam Frugi op te vatten.

Zie Schanz-Hosius: „Geschichte der Röm. Litteratur" Is pag. 195.

\section{V}

De mededeeling, dat Cato in zijn Origines de namen der veldheeren verzweeg, moet letterlijk opgevat worden.

C. J. C. ARNOLD 


\section{VI}

De uitgang -ris voor den 2en Sing. Indic. Med. Pass., secundair ontstaan naar analogie van den overeenkomstigen vorm in het actief, dient bij Plautus tot emphasis en differentiatie.

\section{VII}

W. E. J. Kuiper meent ten onrechte, dat in Theophrastes Charact.

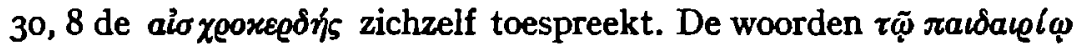
moeten niet als een glosse beschouwd worden.

W. E. J. Kuiper: ,,Theophrastes' Zedeprenten”, pag. 117 .

\section{VIII}

Bij Propertius I, 9, 30 behoude men de lezing van alle codices "aufuge".

\section{IX}

Ten onrechte vertalen de Labriolle en Hoffmann de woorden „,novissimarum rerum" in August. Conf. II 2, 3 respect. door „,chaque objet nouveau" en ,.jede neue Erscheinung."

\section{$\mathbf{X}$}

August. Serm. ed. Morin Guelf. IX 3 beteekent „facit delectationem" niet ,delectat", zooals Mohrmann (Annus Festivus p. 127) schrijft.

\section{XI}

Aeschylus Agam. vers 87I

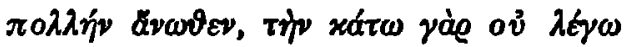

moet als onecht verworpen worden. 


\section{XII}

Aesch. Agam. vers 925

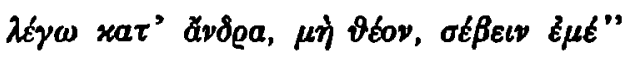

dient men als echt te handhaven.

\section{XIII}

Het oordeel van Cicero over Philistus van Syracuse (Epist. ad Quintum fr. II 13,4 ) is onjuist.

\section{XIV}

Het is wenschelijk het maken van het Latijnsche opstel in de vijfde en zesde klasse van het gymnasium weer in te voeren. 




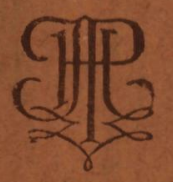

